\title{
Ecbasis Cuiusdam Captivi Per \\ Tropologiam- \\ Escape of a Certain \\ Captive Told in a \\ Figurative Manner
}

An Eleventh-Century Latin Beast Epic

Translated by

Edwin H. Zeydel 
Ecbasis Cuiusdam Captivi Per TropologiamEscape of a Certain Captive Told in a Figurative Manner 
From 1949 to 2004, UNC Press and the UNC Department of Germanic \& Slavic Languages and Literatures published the UNC Studies in the Germanic Languages and Literatures series. Monographs, anthologies, and critical editions in the series covered an array of topics including medieval and modern literature, theater, linguistics, philology, onomastics, and the history of ideas. Through the generous support of the National Endowment for the Humanities and the Andrew W. Mellon Foundation, books in the series have been reissued in new paperback and open access digital editions. For a complete list of books visit www.uncpress.org. 


\section{Ecbasis Cuiusdam Captivi Per Tropologiam-Escape of a Certain Captive Told in a}

\section{Figurative Manner}

An Eleventh-Century Latin Beast Epic

TRANSLATED BY EDWIN H. ZEYDEL

UNC Studies in the Germanic Languages and Literatures Number 46 
Copyright (C) 1964

This work is licensed under a Creative Commons CC BY-NC-ND license. To view a copy of the license, visit http://creativecommons. org/licenses.

Suggested citation: Zeydel, Edwin H. Ecbasis Cuiusdam Captivi Per Tropologiam-Escape of a Certain Captive Told in a Figurative Manner: An Eleventh-Century Latin Beast Epic. Chapel Hill: University of North Carolina Press, 1964. DoI: https://doi.org/ 10.5149/9781469658643_ Zeydel

Library of Congress Cataloging-in-Publication Data Names: Zeydel, Edwin H.

Title: Ecbasis cuiusdam captivi per tropologiam - Escape of a certain captive told in a figurative manner : An eleventh-century Latin beast epic / by Edwin H. Zeydel.

Other titles: University of North Carolina Studies in the Germanic Languages and Literatures ; no. 46.

Description: Chapel Hill : University of North Carolina Press, [1964] Series: University of North Carolina Studies in the Germanic Languages and Literatures.

Identifiers: LCCN 64064252 | ISBN 978-0-8078-8846-9 (pbk: alk. paper) | ISBN 978-1-4696-5864-3 (ebook)

Subjects: Centos.

Classification: LCC PD25 .N6 NO. 46 




\section{PREFACE}

Jacob Grimm called the Ecbasis cuiusdam Captivi the oldest beast epic of the Middle Ages, and others have followed him in this. Whether or not this judgment is correct, the work deserves more attention than it has been accorded and, in my opinion, a higher evaluation than that given it by any writer from the time of Grimm, its discoverer and first editor, down to the present. None of the critics has more than hinted at the several original qualities which characterize it as one of the most clever and many-faceted works of the mid-eleventh century. These virtues will be discussed in the Introduction.

No satisfactory translation in any language exists. The two German renderings are old, depend on a poor text and are inaccurate as well as inaccessible. Another more recent partial translation in German is also untrustworthy. There is no English translation at all and no discussion, although the work represents a significant step in the development of the European beast fable. An exception is F.J.E. Raby, who gives a good summary of its contents in his History of Secular Latin Poetry in the Middle Ages I, 1934, 269 ff. (2 nd ed., 1957).

My translation, in prose, is as literal a line-for-line rendering as I could make it, even with respect to the author's illogical use of tenses. The Latin appears face to face with the English translation. It was felt that many may wish to see the Ecbasis in its original form, even if their knowledge of Latin is imperfect, while those who read Middle Latin will no doubt want an opportunity to compare it conveniently with the English.

The Latin text as I print it is a composite in that it offers what I consider the best reading or conjecture in every case. But where the text deviates from the manuscripts, the manuscript readings are expressly noted in the Commentary. The text found in Strecker's edition, first published in 1935, is thus occasionally altered to bring it up to date, and to conform to the present-day status of Ecbasis criticism. In no sense, however, is my work to be interpreted as a new critical text edition, although I have attempted to add to the research of others. Its main purpose is to make this important work available to English-speaking 
scholars, students and general readers in the best possible form. It leans heavily upon its predecessors, especially Grimm, Voigt and Strecker, most of all on the last-mentioned.

The Ecbasis is a cento. Numerous lines are more or less reminiscent of, even identical with, lines in Horace, fewer have the same relationship to Virgil, some to Ovid and other Roman writers, more to Prudentius, and a considerable number to other late Christian writers. I discuss the Ecbasis from this point of view in the Introduction, offering a new approach to this phase of Ecbasis scholarship and calling attention in particular to its use of Horace and Virgil. I do not repeat the catalog of authors and lines which is found in Strecker's edition, pp. 46-51. The reader is referred to this work.

It is to be regretted that World War II and death deprived scholarship of the more ambitious Monumenta edition of the Ecbasis which Strecker was planning with the help of the preliminary studies left by Paul von Winterfeld after his death, which would also have contained the results of the research of Norbert Fickermann of Berlin. In this respect too the present edition, like my edition of Ruodlieb, now in its second printing in this same series, is not to be regarded as an attempt to take the place of any planned Monumenta edition.

The Introduction aims to present the unfamiliar Ecbasis to the Englishspeaking public for what it is - one of the more sprightly and entertaining works of the eleventh century in Europe - and to familiarize it with the many literary problems involved. While it is based partly upon my article "Betrachtungen über die Ecbasis captivi" in Mittellateinisches Jahrbuch II, dedicated to Professor Karl Langosch of Cologne, much new material and new points of view have been added here.

The Bibliography attached to the Introduction, while not exhaustive, lists all the more important material that has come to my attention, and serves also as a key to allusions to the works in question found throughout the book.

The Commentary combines information of a linguistic, historical and cultural nature and at the same time is devoted to textual matters. As already noted, a profound debt is to be acknowledged to predecessors. Ecbasis scholarship would indeed be the poorer without their contribution.

The Appendix offers the Latin text, with an English translation, of an earlier (probabiy eighth-century) poem in elegiac distichs which is clearly a forerunner of the Ecbasis, although there is little likelihood that it was familiar to our author. This poem shows that the Aesopian fable of the sick lion, with vari- 
ations, was not unknown in northern Europe in the eleventh century, when the Ecbasis was written.

This is the sixth volume in the present series in which I have been involved directly. It is a pleasure again to acknowledge the never-failing helpfulness and friendliness of its Publication Committee, and in particular of its editor, Professor Frederic E. Coenen, to whom his Germanist colleagues everywhere owe gratitude.

Cincinnati, Ohio

EDWIN H. ZEYDEL 



\section{CONTENTS}

\section{INTRODUCTION}

1. The Importance of the Ecbasis; its Contents . . . . . . . . . . . 1

2. The Middle Latin Literature of Germany as German Literature. . . 2

3. Manuscripts and Title . . . . . . . . . . . . . . . . . . . . 4

4. Date and Authorship. . . . . . . . . . . . . . . . 5

5. The Plot . . . . . . . . . . . . . . . . . 9

6. A Critique of the Ecbasis . . . . . . . . . . . . . . . . . . . 11

7. The Ecbasis as a Cento . . . . . . . . . . . . . . . . . . . . 13

8. Translations. . . . . . . . . . . . . . . . . 15

9. Interpolation . . . . . . . . . . . . . . . . . . . . . . 17

TEXT

Latin . . . . . . . . . . . . . . . . . . . . . 22

English . . . . . . . . . . . . . . . . . 23

A P PENDIX: The Fable "Aegrum fama fuit...” . . . . . . . . . . . 97

COMMENTARY. . . . . . . . . . . . . . . . . . 103 



\section{INTRODUCTION}

\section{THE IMPORTANCE OF THE ECBASIS; ITS EDITORS}

Neither Jacob Grimm, who discovered the Ecbasis in Brussels in 1834 and four years later published it for the first time in Lateinische Gedichte des X. und XI. Jahrhunderts, ${ }^{1}$ nor Ernst Voigt, its second editor (Voigt ed.), 1875, lavished much praise upon the work. Grimm assigned it "far less value" than the epic Waltharius, which is probably over one hundred years older, and Voigt, referring to the Ecbasis author's borrowings from earlier authors, even accused him of plagiarism. In general later critics agree with Grimm's appraisal. Werner Ross, p. 281, claims that it has left no mark upon subsequent writers ${ }^{2}$ and adds that we would render it too much honor by applying present-day esthetic standards. Karl Langosch (Reallex.) recognized the skill of the author in giving his work epic form and praised its "original features," but felt that it does not belong to the great literary achievements of its time. Strecker, the third editor (Ermini, Poeti contains only selections), whose edition is now regarded as standard, never uttered a general critical opinion of the Ecbasis. Since 1935, certainly, when Strecker's edition appeared for the first time, Voigt's redaction has suffered eclipse, although it has by no means lost all its value even now. Strecker is right in calling it "a model of industry and care" but treats it too harshly otherwise. Although Voigt's introduction has not stood up against the results of research, we owe him about twenty valuable textual improvements and many more correct interpretations of difficult words and passages. As for Strecker's edition, designed to be followed by the much fuller one in the Monumenta series which never appeared, Schumann criticised it quite effectively. Its main shortcoming is that, for a work designed as a school edition, it leaves the reader too often in the air and caters rather to the ex-

${ }^{1}$ The principal works to be cited in the Introduction and the Commentary are listed in the Bibliography following this Introduction. Henceforth they will be referred to in the abbreviated form indicated.

2 On this subject see Strecker: Ecbasisfragen, also section 6 below. 
perienced specialist. Consequently Strecker's own criticism of his predecessor Voigt that he sometimes aims wide of the mark, can justly be applied to Strecker himself.

However, in spite of the faint praise bestowed upon the Ecbasis during the first one hundred twerity-five years of critical preoccupation with it, and the unhistorical and anachronistic attempts to judge it on the basis of modern esthetic standards, the Ecbasis possesses a value beyond that which a work some 925 years old would normally have. Its value and interest are much greater than the critics have realized. It represents a blending of many genres unusual for its time, which is one of several marks of its striking originality. It contains excellent characterization. It deserves an important, though controversial, place among medieval Aesopian beast fables. Though clad in the garb of a bestiary, it presents remarkable Easter cartata or oratorio passages, in which nightingale, blackbird, parrot and swan participate. It is characterized by a high degree of wit, humor and satire, which appear not only in sly allusions to people and places, and in telling mock-heroism, but also in reminiscences of such ancient writers as Horace, Virgil and Prudentius. At times these are introdticed with a deliberate incongruousness which must have had a hilarious effect upon contemporaries. Incidentally it contains some readings of ancient writers which go back to very old manuscripts. ${ }^{1}$ Finally it is the work of a maturing, pensive man who as a youth was discolus (1.124), whose life has been a struggle, who is discontented with his world and his own ways, but not too old to resolve to make a new start. Such a confession by an author of the mid-eleventh century is unusual if not unique. Is this the mark of a Germanic, Faustian temperament?

\section{THE MIDDLE LATIN LITERATURE OF GERMANY}

\section{AS GERMAN LITERATURE}

This suggests observations of a broader scope which concern the entire body of Middle Latin literature as we meet it on German soil. The fact that this literature, in a language not familiar to many Germanists today, has been much neglected, obscures the problems which should be aired. A vital question is raised when critics ask whether this literature is a part of German literature at

\footnotetext{
' See the Commentary on 1. 282. The qualities of the Ecbasis will be further discussed below in section 6 .
} 
all, or a supranational, cosmopolitan, priestly phenomenon of its own. One of the best-known literary scholars in Germany today, Helmut de Boor, is particularly emphatic in asserting that the Middle Latin literature of Germany is alien to the history of German literature. ${ }^{1}$

I am not convinced by de Boor's arguments, for I believe that Waltharius, Hrostvit, Ruodlieb and Ecbasis, is well as the Latin hymns and secular poems originating in Germany are not only important poetical products of their time on German soil, throwing light upon the "intellectual counteriance" of their respective ages, but also form a part of the framework of German literaiy history. Though they may be "cosmopolitan" to a certain degrce, they do not issue exclusively from a "supranational" area; they offer at the same time an insight into the progress of German literature and belong "in the stream of that literature." It should be realized that the "intellectual atmosphere" of the German monasteries is just as much a part of German cultural life as any lay ruler's court in Germany, also that if in part the lighter fictional reading and writing of the monks and clergy wore not of a "popular" nature - all the quoted words and phrases are from de Boor -, then the same charges may be made against much of the literature of Gerratany, in German, of the sixteenth century and surely also against many of the tragedies of Gryphius. If this German-Latin literature had no German earmarks, von Winterfeld and Strecker would hardly have found the neans of refuting French chauvinists (in an era now gone forever, it is to be hoped) when they laid claim to some of these works, including the Echasis, for France.

It seems safe to say that in the tenth century, certainly in the eleventh, there no longer existed a homogeneous clergy in Europe because regional attachment and ethnic differences had already made theinselves feli. Middle Latin poetry had by that time assumed a regional (at times almost national) stamp in the various socio-ethnic areas, and every significant work originating on German soil necessarily bore the criteria of the German area.

Although this is not the place to labor the point, it may be appropriate to call attention to such a poein as the tenth-century Carmen Cantabrigiensium of German origin called "Modus Ottinc," in which Emperor Otto I is celebrated for a battle in which "centum Teutones" bring defeat to "milibus Parthiis" (i.e., Hungarians or Huns). Again, in the poem "Hospita in Gallia," discovered by

${ }^{1}$ Die deutsche Literatur von Kill 'le'm Grossen bis zum Beginn der höfischen Dichtung: 7701170. München, 1949, $96 \mathrm{ts}$. 
J. Werner and first published in his Beiträge zur Kunde der lateinischen Literatur des Mittelalters (1905), the twelfth-century scholaris vagans takes a sad farewell from his beloved Swabia:

\author{
Vale, dulcis patria, \\ Suavis Suevorum Suevia.
}

Are these not clear examples of what may be called at least cultural patriotism?

Moreover, to anyone comparing the Gallic Hugh of Orléans (styled Primas) and Walter of Chatillon with the Teutonic Archipoeta, all writing in the twelfth century, the Gallic characteristics of the first two contrast sharply with the Teutonic traits of the third.

As early as 1907 the Middle Latin scholar Eduard Norden had correctly maintained: "A literary history of the declining occidental world must be classified geographically... a particularized development of the provincial literatures is clearly discernible." I I will devote a later article to this.

\title{
III. MANUSCRIPTS AND TITLE
}

There are two manuscripts of the Ecbasis in existence, A and B, now both in the Royal Library in Brussels. They may have come from the monastery of St. Eucharius (later St. Matthias) in Trèves (Trier). A, written in the middle of the twelfth century, has been studied frequently, B somewhat less. Grimm, their discoverer, realized that B was younger but believed they had a common source. He used A almost exclusively. Since Grimm's time it has been established, chiefly by L. Traube, that B was copied from A. Yet B offers a few superior readings (e.g. 1. 363). A originally contained numerous errors, but these were corrected by the scribe himself and by at least two later correctors. Some of these corrections have been incorporated in B. While B bears no title, A is superscribed: Ecbasis cuiusdam captivi per tropologiam (the last word corrected by Grimm from "topologiam"). The word ecbasis (a correction from "hec basis") can be traced through Greek literature from Homer to Menander and Polybius, often in the sense of "debarkation" or, in general "exit." In Latin, Servius uses it as "digression," and in glosses it is explained as "egressus, exitus."

"Tropologia" occurs often in Greek and Roman rhetoricians and Church

${ }^{1}$ Eduard Norden, Die lateinische Literatur im Übergang vom Altertum zum Mittelalter, in Die Kultur der Gegenwart I, 8, 2nd ed., 1907, $402 \mathrm{f}$.

${ }^{2}$ See also Leitzmann in Paul-Braune Beiträge 41, 1916, 183, and Commentary on 1. 259. 


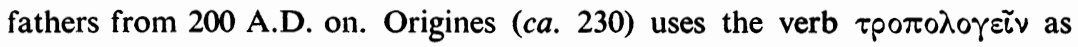
"to interpret allegorically," while the noun $\tau \rho \circ \pi \circ \lambda \circ \gamma i \alpha$ means "figural speech" in Photius ( $c a .850$ ). In Latin both St. Jerome and Apollinaris Sidonius in the fifth century use the noun and adjective as "allegorical, metaphorical speech" and "metaphorical," respectively. Consequently the title of the work means: "How a certain captive escaped (i.e. strayed from home), told in a figurative, metaphorical manner." The metaphorical element refers to the use of animals to represent men. Concerning the figural element in the Middle Ages see Erich Auerbach's Mimesis, also the Ecbasis, 11. $39 \mathrm{ff}$.

\section{DATE AND AUTHORSHIP}

Grimm reached the conclusion that the Ecbasis was written in the tenth century, i.e. before 936 . This date stood for over one hundred years. Voigt and Strecker ${ }^{1}$ agreed to it. But Grimm himself was not quite sure and reserved a possible later date - before 1056. This depended largely on whether Emperors Conrad I (ob. 918) and Henry I (ob. 936) or Conrad II (ob. 1039) and Henry III (ob. 1056) were involved in 11.132 and 254, and 685 and 1149, respectively. Erdmann fixed the date between 1043 and 1046. Authorities like Langosch and Lehmann agree, but some histories of literature, out of ignorance more than conviction, still speak of 930. But at least three writers on the Ecbasis, Ross, G. Vinay and Jauss, deliberately reject Erdmann's arguments and assign the Ecbasis again to the early tenth century (912). In doing so they ignore the fact that in 1890 Zacher, who had decided to endorse a very early date, had been refuted by Zarncke.

Ross, misled by this oversight, goes back to 912 . He relies upon 1.69 of the Ecbasis but overlooks the highly developed original leonine hexameters of the poem, which would hardly have been conceivable as early as 912 , also the advanced degree of humanization of the animals, and the intimate familiarity with Horace. To be sure, the Satires and Epistles of Horace were available in some French and German monasteries as early as the tenth century but were hardly common knowledge by then. ${ }^{2}$

\footnotetext{
${ }^{1}$ Later however (in the 'forties) Strecker was convinced by Erdmann (p. 383) that the work originated in the eleventh century.

${ }^{2}$ See Pertz 2, 125 and 536; M. Manutius, Analekten zur Geschichte des Horaz im Mittelalter bis 1300, 1893; also the literature given by Ross, 268. But Voigt goes too far in thinking that all non-leonine lines are borrowed.
} 
Possibly an incidental remark of Ross (already uttered by Erdmann) descrves serious attention, viz. that Henry might refer to the French king Henry I, who from 1031 to 1039 ruled concurrently with the German emperor Conrad 11. Since Conrad and Henry both seem to be living in the Ecbasis, this is a suggestion worth bearing in mind.

It should also be noted in connection with the hereditary enfeoffment of the fox by the king (11. 1005-1013; 1119), that such enfeoftment did not become customary before the time of Conrad II. Reference too should be made to 1. 1149:

In regum numero regnas Cuonone secundus,

which might be interpreted: "Among the kings you rule as the next to Conrad." If we accept the questionable syntax Cuonone (Cuononi?) secundus without the Horatian $a b$ (Sat. 2, 3, 193) there could still be a hidden reference to Cuono secundus in the latter word. But if we join Peiper, who read Cuonone secundo, the allusion would no longer be hidden and in addition would constitute a good monastic jest (Conrad II can not compare with you!). Ll. 685 and 727 may also point to eleventh-century conditions.

As for the French king Henry $\mathrm{l}$, he is in history a constantly embattled ruler, ever involved in struggles with nobility and clergy. Could not 1. 132:

Henrici placitis cepi moderamina pacis

play ironically upon his stormy career?

Doubtless one feels partial to the German empcror Henry un as a result of Erdmann's discoveries. On the other hand i1. $254 \mathrm{f}$.:

Si daret Heinricus, vobis percarus amicus,

Porcos quingentos, vitulos totidem saginatos...

confront us with a quality for which this Henry was but little known. But that may be ironical. At any rate, it seems striking that in the Ecbasis both Conrad and Henry are living rulers.

The question of authorship of the Ecbasis presents even greater difficulty than that of its date. Grimm's attempt to ascribe it to a monastic Malchus, the name of the St. Jerome hero whose story the unicorn recounts, has found no echo. Voigt, p. 14, merely calls the author "the monk of St. Aper," while Strecker leaves the question open. But in 1957 A'ton Michel proposed with confidence that Humbert, the later cardinal of Silva Candida, who lived in the eleventh century, was the author. If Michel had been less ambitious and refrained from 
weakening his contention with linguistic paralleis, which merely reflect the scholastic tradition of Toul, he might have been more convincing. Lehmann, Langosch (on Michel) and Brunhölzl all reject his arguments.

We assume, contrary to Wilmotte in Revue historique 127, 2, that the author was of Germanic stock, perhaps Alemannic from the Black Forest region, or East Franconian, but for many years active as a Benedictine monk and teacher in the Lorraine borderland near. Toul, certainly pro-German, Hartmut Hoffmann, however, relocates his home in Trèves because the manuscripts seem to hail from there. He wrote the work perhaps in part as a declamatory school exercise - see 1. 42, as well as the designation of roles, or speakers, in MS A -, also as an expression of his satiric-parodistic urge.

It is less likely that he himself ever fled from his monastery or even wanted to flee, ${ }^{1}$ although he was restive under the stern monastic regulations and uinhappy with monastic fare. Two considerations point to the fact that the flight and captivity of the calf are based on literary tradition rather than on any actual experience of the author.

The one is St. Jerome's tals of Malchus, just referred to, which the unicorn recounts in the course of the "inner plot" (11.583 and 790). The story concerns a chaste hero of Mesopotamia who flees from home to avoid being forced by his parents into marriage and who enters a Syrian monastery. There he spends many years. When his father dies, the abbot tries to keep him in the monastery, but in vain. The abbot says to him: "Ovis quae de ovilibus egreditur, lupi statim morsibus patet." On the way home he with others falls into the hands of the Ismaelites. Together with a chaste woman he is forced into servitude under the same master. $\mathrm{He}$ and this woman vow chastity to one another. Escaping, they are pursued by their Ismaelite master and a slave. They hide in a cave. The master sends the slave ahead to urge them to return, but the latter is killed by a lion. The master who follows him suffers the same fate. The fugitives happily reach home and dedicate their lives to the Lord, settling in Syria and continuing thzir platonic affection for each other.

The other point to be noted which indicates literary tradition with regard to the flight is the sentiment expressed in 11. 66 and 248, which bear a striking resemblance to a hexameter in common use as early as the tenth century as a penmanship exercise, and comparable to such a present-day typewriter exercise

' Erdmann, 382, and most other recent writers reject the idea of physical flight. Hartmut Hoffmann, however, impalle 1 by his argument connecting the Eciasis with Poppo of Trèves, believes that he actually ilad. 
as "Now is the time for all good men to come to the aid of their party" (see Hartmut Hoffmann!). It was much used in monasteries in South Germany and goes:

\section{Infelix vitulus sudibus quam sepe ligatus. ${ }^{1}$}

The close similarity of the two Ecbasis lines thereto suggests that the author slyly built the variations of the well-known exercise (not once, but twice! - see also 1. 308) into his poem and, in fact, used its sentiment as a key to the plot centering around the imprisoned calf.

There is reason, then, to contradict Grimm and to maintain that the motif of the flight (Malchus) and captivity (infelix vitulus) of the calf (or sheep, according to Malchus's abbot) is older than the Ecbasis, but not necessarily autobiographical. Besides, recaptured fugitives from monasteries were not as a rule employed as teachers and were hardly entrusted with anything as precious as parchment or other writing materials. But perhaps the author was physically handicapped and unable to participate in the normal activities of the monks. A characterization of him has already been suggested above.

Why did he write this work? Although it is difficult to determine the motivation of a writer who lived 925 years ago, it is possible, in the present case, to hazard some guesses. As he himself says in 1. 42, he meant the work to be recited (and enjoyed) by his pupils and fellow monks. Since Horace was his favorite author, he may have been encouraged by his example to use fables as a foundation. In Sat. 2, 6, one of his most pleasing, Horace employs the fable of the city mouse and the field mouse, ${ }^{1}$ as Hartmut Hoffmann notes. But even without Horace, the Aesopian tradition was known in northern Europe as early as the eighth century in the poem of the sick lion, "Aegrum fama fuit" (Mon. Germ. Hist., Poetae 1, 62-64), where the bear instead of the wolf is the fox's foe and the fox's excuse for lateness is that his shoe leather wore out while he was seeking help for the lion. This is published in the Appendix. Then in the tenth-century poem Metrum leonis, probably by Leo of Vercelli (ibid. $5^{2}$, 483-489) there are hints of the roles played by fox and wolf in the Ecbasis and in Ysengrimus of the twelfth century. Here the fox, though not yet the wolf's foe, intrigues shrewdly against him to destroy him by taking advantage of his

\footnotetext{
' See Strecker ed., critical apparatus to 1. 248, p. 9; also Bischoff, 13; Erdmann, 383 f.; and Ross, 280. The last-mentioned erroneously calls this an Ecbasis verse." The last three words of 1. 248 echo Hor. Carm. 4, 11, $23 \mathrm{f}$.

${ }^{2}$ See also Epistles 1, 7, $11.29 \mathrm{ff}$., where the fable of fox and weasel is alluded to.
} 
conceit. Possibly our author was familiar with this, but it is so fragmentary, textually corrupt and difficult to construe that there is no point in publishing it here. The precise date of the events of the "outer fable" - 812-might indicate an earlier source too.

The penmanship exercise and the author's own unhappiness in the monastery might have strengthened his resolution to use the fable form and offered the literary idea of flight. So did the Malchus story, as well as the tale Reparatio lapsi, mentioned in 1. 220 (see Commentary), which assures the repentant sinner of eventual salvation. Being satirically inclined and not without humor, he introduced allusions to clergy and nobility, larded his work with echoes (some obvious, some slyly hidden, some witty by virtue of a new, incongruous context) of Roman and later Christian writers known only too well to inmates of the monastery. Finally, since tradition already linked bestiaries with the Easter season, he wove appropriate interludes into the texture of his work. In short, he strove to reveal his many talents from many angles.

\section{THE PLOT}

The first sixty-eight lines present the writer's characterization of himself, his apologia and reason for writing as well as for giving his work its present form. They serve as a transition to the "outer fable" at the point when he compares himself with the escaping calf.

The "outer fable" extends from 11. 69 to 391 and relates how at Eastertime the escaped calf falls into the clutches of the "forester" (the wolf), who talks like a monk. The calf is taken to his cave but given a day's respite of life. The wolf himself serves the calf a meal, in keeping with the practice of fattening a sacrificial animal before it is slaughtered. At midnight otter and hedgehog are welcomed as returning messengers of the wolf, bearing fish, herbs and fruits. The otter is designated to guard the calf. Lulled to sleep to the accompaniment of a zither, the wolf awakens and asks his friends to explain a disturbing dream that he has just had. He is told that it represents a warning not to harm the calf. For seven years, it is claimed, the wolf has had a clean record of abstaining from blood sacrifices. Nevertheless he persists in his gluttonous plan, comparing the calf with an Easter lamb. Meanwhile the Wasgau (Vosges) dog has told the animals of the village, corralled by their shepherd, about the calf's plight and led them to the cave. The wolf is worried and admits that he most fears his 
enemy, the fox, and urges his friends to resist the intruders. They demur and ask why the wolf and the fox are enemies.

The "inner (Aesopian) fable" extends from 1. 392 to 1097 and constitutes the wolf's answer. Some generations ago, also at Eastertime, the lion, king of the beasts, was ill. All the anima!s save the fox came with cures. At the chamberlain's (the wolf's) suggestion the fox was to be hanged for his remissness, and so he made a gallows ready. The panther stealthily carried this news to the recreant, whereupon after solemn religious exercises the fox appeared at court and justified himself with a preposterous tale of a pilgrimage to the Holy Land. He recommended a cure for the invalid. After flaying the woif and applying salves to the ailing king, the wolf's pelt was to serve as a warming blanket for him.

After this advice the "monastic" yea "Olympian" fox became the new favorite and regent. He now acted dubiously but strictly according to monastic rules, and no animal protested against his conduct. The leopard, appointed majordomo, later also psalmist and singer of hymns, instiucted the court retainers in the care of the patient and gave them duties. The unicorn, a maiden, recited St. Jerome's story of Malchus. The proud recalcitrant hedgehog was punished. The panther, intriguing with the fox, was designated and anointed as the lion's heir amid feasting and celebration. Two singers, the nightingale and the blackbird, are now introduced by the panther. They touch the hearts of the beasts with their song about the king's sufferings and the passion of Christ. After finishing their singing - too sad for the Easter season, the panther thinks they bathe in the Gironde estuary, near Bordeaux. Two strangers, the parrot and the swan, join them and tell of a long journey. They follow the other two birds to court, to contribute to the Easter festivities and to celebrate the Resurrection.

Mcanwhile the king's health has improved, chiefly perhaps because of some wine from Trèves and much lavish feasting. The fox receives a fief as his reward. The feast over, the carousing beasts, scorning the dying wolf, stagger home. The parrot begs the nightingale to sing the recuperating king into a three-day sleep. Finally the king and his guests leave the court, the fox writes the wolf's epitaph and, escorted by the leopard, seeks his new fief.

We revert to the "outer fable" (1. 1098). The otter has observed the besieging foe, reports his observations to the wolf and dives cravenly into the river. The equally cowardly hedgehog, the owner of Stensile (perhaps representing a boastful nobleman), seeks to hide, but the wolf, misled by clever words of the 
fox, shows himself to the hostile crowd, while the calf, releasing the latch, escapes. The wolf is impaled by the steer, and the fox writes his epitaph. On the way home the calf tells his mother of his experiences in the cave, which is described as a den of iniquity, while the wolf is referred to as Herod. But the calf adnits he lost no sleep that night.

In the last six lines the poet again speaks in his own name, as he had at the beginning. He resolves to turn his back on trifles in favor of psalms. Angry with himself for his shortcomings, he vows henceforth to remain silent.

\section{A CRITIQUE OI: THE ECBASIS}

Considering the Ecbasis as a work of imaginative literature, we have found it to be rich in wit and humor, satire and ireny. It also contains parodistic sallies. Some of the targets are the hypocrisy of the lower clergy in hiding their own greed under a mantle of holiness, a holier-than-thou attitude, distrust of authority in the monastery, superiors who indulge in platitudes (cf. 11. 505, 829, 991, 1001), gluttony, excessive dirinking, unsanitary kitchens and servers, unwarranted pride in one's ancestry, and braggadocio. But the barbs are never pointed against the Church or against essential ecclesiastical men or matters. Many detailed allusions of course escape us after 925 years, in spite of the efforts of Hartmut Hoffmann. Indeed, Aristophanes, who wrote some 2350 years ago, seems cioser to us in soms respects. In part, certainly, the Echasis is to be classified as "light-hearted monastic literature," as Ross asserts." But it should not be overlooked that this humor is of the typical medieval brand, in which jest and seriousness impinge upon one another.

To class the Ecbasis with Ross as light-hearted monastic literature solves the problem of genre only in part, however. The work constitutes also monastic literature of a serious strain. Consider the introduction of the section beginning with 1.831:

\section{Nunc tamen amoto queramus seria ludo...}

The caniata of the nightingale and blackbird intoning the passion of the Lord is too lugubrious even for the panther. Moreover, the work is more

\footnotetext{
'Peiper had called attention as early as 1876 to the parodistic element. In this the Ecbasis is exceptional, for "parodies of cpic style-patterns" are quite rare before the twelfth century. See Paul Lehmann, Die Parodic im Mutelalter, 1922, 31. This would offer further evidence that the Ecbasis can hardly date from as early as the tenth century.
} 
than a monastic poem, light-hearted or serious, and like Ruodlieb reaches out beyond monastic life and into that of the mime and the secular world. Although Hartmut Hoffmann may go too far in his attempt to connect it with events of its day, particularly as they concern the pilgrimage of Archbishop Poppo of Trèves and his troubles with Count Giselbert of Salm, yet it cannot be denied that the Ecbasis deals satirically too with the aristocratic laity. Vinay sees in it a reflection of Franco-German rivalry in Lorraine.

The hedgehog and the otter may be caricatures of certain contemporary nobles. We must note too what Hoffmann says about the cygnus-psitacus interlude beginning with 1.938. Here he detects satire against a brand of worldly wisdom which goes hand in hand with an official religiosity willing to make concessions to the lukewarm and to blink at questionable intrigues. There is evidence that charges of such hypocricy were actually levelled against Emperor Henry III by writers in the western part of the empire, where the Ecbasis was written. ${ }^{1}$

Ross and Jauss agree that the Ecbasis is not "the oldest beast epic." Ross, p. 281 , looks at the work as merely one attempt among many to give the material literary form. Though this may be true, we today do not possess these "many" versions. The appropriateness of the term "epic" as applying to the Ecbasis has also been questioned. True, the enmity of fox and wolf, like the fable-form itself, can hardly be called epic in quality, ${ }^{2}$ and the characters of the work still retain elements of the typical. But it would be wrong, as Jauss does, to deny the work all epic qualities, however imperfect they may be. It reveals elements of the inchoate mock-heroic epic, in that it is composed in heroic hexameters, contains a reference, though not an invocation, to the muses, is rich in persiflage, introduces actors who, though not taken from hero-lore, represent familiar traditional types in the guise of various animals known for certain qualities (the gullible ruler, the shrewd self-seeking adviser pitted against the dull heavy-handed counselor). Its plot centers around the enmity of the two protagonists caused by the attempt of one to wreak the other's downfall. Consequently the term "oldest beast epic," perhaps with the qualification "known to us today," can still be used legitimately to describe an essential character of this unholy secular bible.

The fable-form as we find it in the Ecbasis is unusual; we are dealing with a

' Concerning satire against the lay aristocracy in the Ecbasis consult also Karl Hauck.

2 The moral of both fables is: "The biter will be bitten," as seen in 1. 767: Decidit in laqueum, quem fraude tetenderat, ipsum. 
fable compounded - a fable-background or frame, within which another fable is mounted. It was also found to present a lively dramatic dialog which begins in the "outer fable" with 1.119 in a conversation between calf and wolf, and in which otter and hedgehog take part. The "inner fable" consists in the main of the wolf's story, but it lapses over into the conversations of the earlier generation of lion, fox, leopard, boar, hedgehog and panther. This dialog is marked by liveliness and dramatic vigor. Beginning with 1. 830 the Easter cantata of the nightingale and her companion, the blackbird, is heard, and in 1.932 the parrot makes his entry with the swan and adds his contribution to the festivities. The satirical and parodistic element was discussed earlier in this section. As for the author's confession of his own shortcomings, it concerns his day-dreaming and trifling, his lack of sociability and his "hoarsevoiced braying," or bitterness and criticism of others while overlooking his own flaws; and his promise to reform.

No doubt, then, the Ecbasis is many-faceted and hybrid. But the term "hybrid" is not necessarily derogatory. The quality of a hybrid depends upon how well its component parts are integrated. The answer to this question may well be left to the reader.

In section 1 above Ross was found to contend that the Ecbasis has left no mark on later literature. But as Voretzsch (Preuss. Jb. 80) and Foulet (Le roman renard, 371), mentioned by Jauss (pp. 84-85), indicate, four points used in later versions of the fable of the sick lion, occur for the first time in the Ecbasis. They are: 1. fox and wolf are uncle and nephew, 2. the wolf has a gallows erected for his foe, 3 . the fox is warned of danger by his friend, the panther, and 4. parallels are suggested between the animal kingdom and the feudal hierarchy. These points have some significance.

\section{THE ECBASIS AS A CENTO}

It is surprising that Grimm and after him Voigt misunderstood almost completely the use of entire lines, partial lines and phrases from about forty poets of antiquity and the early Middle Ages, primarily Horace, Virgil and Prudentius. The Ecbasis contains about 230 borrowings (ranging from slight to word-forword) from Horace, 90 from Prudentius, 50 from Virgil, fewer from Ovid and other Roman writers, and about one hundred from late Christian authors other than Prudentius. ${ }^{1}$ It is a mosaic, so to speak.

${ }^{1}$ The original lines are usually leonine. See p. 5, footnote 2 above. 
As already noted, the Ecbasis author made his work a cento for very specific purposes, not least for humorous or mock-heroic effect. Probably his pupils found great pleasure in discovering these borrowings and identifying them, as a detective would. It may be too that this activity was a part of their scholastic requirements. It is certain that such a line as 434:

Non tamen indecorem sua se regina relinquit,

borrowed from a very dramatic passage in the Aeneid 11, 845, achieved a decided parodistic, mock-heroic effect. This is increased when one considers that the queen in this case is the shrewd fox, the reward that "she" offers, fox gold, and the recipient is the panther. In this connection Hoffmann, p. 301, thinks of Queen Gisela, the mother of Emperor Henry III. Humorous too is the variation of Horace Ep. 2, 2, 104 in 1. 411, where Horace's finitis studiis becomes finitis stadiis.

To determine how far the Ecbasis may be regarded a Horatian-Virgilian cento, the work has been studied on the basis of Strecker's data in his edition, pp. $46 \mathrm{ff}$. The purpose was to determine how many lines derive wholly, or nearly so, from Horace and Virgil - over one-half of the borrowings are from them -, how many are borrowed in part, and how many contain only faint echoes. The result is that approximately one-fourth of the lines contain reminiscences of Horace or Virgil, but of these fewer than eighty are identical or almost so.

Among the first 300 lines of the poem the following are identical: 11. 74 (combination of two), 114, 116 (combination), 118-120, 141, 142-144, 154-155, $160,162,182,200,207,214,218-219$. Proverbial material such as students would more easily remember is preferred. It is apparent too that the identity sometimes extends over two or three consecutive lines. Example:

Ecb. $114 \mathrm{f} .: \quad$ Cum prorepserunt primis animalia terris, Mutum et pingue pecus nobis fabricaverat usus.

Hor. Sat. 1, 3, 99-102: Cum prorepserunt primis animalia terris, Mutum et turpe, glandem atque cubilia propter Unguibus et pugnis, dein fustibus atque ita porro Pugnabant armis, quae post fabricaverat usus...

Sat. 2, 6, 14: Pingue pecus domino facias...

Sometimes a line is taken one-half from Horace and one-half from Virgil: 
Ecb. 225: Ut te collaudem...geminumque parentum

Hor. Sat. 1, 6, 70: Ut me collaudem...

Virg. Aen. 3, 180: geminosque parentes...

Approximately a dozen of the first 300 lines stem fifty per cent from Horace or Virgil. Examples: 11. 4, 44, 117, 123. The rest, i.e., one-half of the total borrowings from these two authors, show only trivial echoes, in some instances so trivial that it seems pedantic to call them echoes at all. Examples:

Ech. 87: distentum toilitui uber

90: lirram pede tundit

111: recreare...tenuatum corpus

124: Imbirisis iuvenis

204: custos si providus adisis

213: Occupat ipse aditum

242: spelea ferarum
Hor. Epod. 2, 46: distenta siccet ubera Virg. Ecl. 4, 21 : distenta capellae ubcra Hor. Arte Poet, 430: tundet pede terram

Hor. Sat. 2, 2, 84: seu recreare volet tenuatum corpus Hor. De art' poet. 161: Imberbis iuvenis Hor. Sat. 2, 6, 15: custos mihi maximus adsis Virg. Aen. 6, 424: Occupat Aeneas aditum $(6,635$ is identical)

Virg. Ecl. 10, 52: spelatea firarum

But, as noted above, the influence of Horace transcends borrowings. He may have helped suggest the fable technique, as well as that of the excursive exemplum. On the use of Horace in the Ecbasis see also the article of Wilmotte.

\section{TRANSLATIONS}

Because of the limited number of readers and even scholars today with a knowledge of Middle Latin, it is important that so significant a work as the Ecbasis should be made available in German and other modern languages. However, not a single satisfactory rendering in any language exists at the moment, although a new German translation has been announced. The present is the first rendering ever to be essayed in English.

Two antiquated German translations exist, now very difficult to procure. The first, by G. A. Weiske, appeared in 1858 in a Program of the "Lateinische Hauptschule" in Halle. It is done in the Nibelungen strophe on the basis of Grimm's edition, before the text of the Ecbasis had been definitely established, and is practically useless today.

The second is by Ernst Gressler (1910), in hexameters. In his review of it Strecker (Strecker-Gressler) notes two types of fliws: 
1. Appearing before von Winterfeld's and Strecker's research, Gressler's work had to rely entirely upon Voigt. While using Zarncke, he overlooks the contributions of Peiper, Seiler and Rathay.

2. He translates too literally and thus becomes unintelligible to those not familiar with the original. To these general criticisms a few more specific ones may be added: 1. Gressler often misinterprets the text. E.g. hospes (1.159) is not "guest;" distractis gazis (1. 186) does not mean "paying in cash;" remulcent (1. 190) is not "kisses;" quisquiliarum (1. 578) not "delay;" compilat (1.660) not "steal;" ore serenus (1.715) not "witty speech;" saltu celebri (1. 764) not "rapid leap." 2. The hexameter form forces him into awkward turns of phrase (11. 605-606).

3. He evades difficulties (11. 15-16), fails to explain obscure allusions (1. 97), and resorts to colorless paraphrases (1.25).

A much more recent attempt to turn the Ecbasis into German is the, up to the moment, only partial prose translation of the late Horst Kusch (1957). But it presents only 11. 392-1097. Kusch's complete rendering is to be published soon, according to an announcement by Winfried Trillitzsch (see footnote 2, p. 17). It is to be hoped that numerous errors which mar the present fragment will be corrected. Some of these will be noted here.

The Latin lines (on opposite pages) are numbered incorrectly in certain places (e.g. 11. 485, 490, 710-730, 830-850), and excellent improvements by Ecbasis scholars are ignored. Examples: Grimm, 11. 693 ff.; Voigt, 1. 741; and Schumann, 11. $759 \mathrm{ff}$. The last-mentioned case is particularly surprising because of Schumann's standing. Certainly Schumann's reassignment of lines, his insertion of semper instead of pardus, and scio for scit are worth incorporation. Among the glaring errors are: 1.393, torquetur, not "endangered;" 1.421, se excutiunt, not "go away;" 1. 422, concepta, not "plans;" 1. 731, citra, not "beyond;" 1.1027, praecoqua, not "overripe." In 1. 394 he translates decanie as though it had been corrected to decatie.

More surprising are several translation errors which Kusch seems to have copied from Gressler: patrinus (1. 496), not "godfather;" compilat (1. 660), see above; and saltu celebri (1. 764), see above. One wonders also about the source for credo (1. 916) and the reason for copying Strecker's immo (1. 961) for $i m o=$ imno $=$ hymno. 


\section{INTER POLATION}

Frequently 1. 1224:

Versus milleni centeni septuageni

has perplexed scholars, who have proposed several solutions in an attempt to use this direct utterance of the author for determining which lines were actually interpolated. Probably Voigt had the correct answer, while Schmidt (Heidbreede-Schmidt) and von Winterfeld, with whom Strecker agrees, were wrong. This is to say that there is only a single interpolation (11. 852-905, i.e., 54 lines). Subtracting these 54 from 1224 (not counting 11 1225-1229) ${ }^{1}$, we get 1170, which is the expected and desired result. Ll. 906 and 907, which von Winterfeld also called interpolated, are therefore genuine.

Ross, 287, and others speak of a "revision" of the Ecbasis by a later monk. There is little evidence for this. In the case of a work of this kind - a genuine cento - such a revision does not seem feasible. ${ }^{2}$ With the exception of the interpolation just discussed, the style of the Ecbasis seems uniform.

\footnotetext{
${ }^{1}$ See also Grimm, 287.

2 For the same reason it is difficult to see how the Waltharius, also a cento, could have been "corrected" by Ekkehard Iv. See Zeydel in "Prolegomena to an English Translation of Waltharius," in Middle Ages - Reformation - Volkskunde. Festschrift for John G. Kunstmann, Chapel Hill, 1959, 21 ff. The article "Die Ecbasis captivi im Lichte der Forschung" by Winfried Trillitzsch in Forschungen und Fortschritte 35, 5, 146ff. became available too late for consideration, but it adds little. The German-Latin, edition of the Ecbasis by Trillitzsch and S. Hoyer is due in the summer of 1964.
} 


\section{B I B L I O G R A P H Y}

Note: This Bibliography aims to list the most important Ecbasis literature and to indicate, where necessary, the abbreviated form in which the various items are referred to in the Introduction and Commentary.

\section{EDITIONS}

J. Grimm - A. SChmeller, Lateinische Gedichte des X. und XI. Jahrhunderts, Göttingen, 1838, pp. ix-xi, 241-330. (Grimm).

E. VoIGT, Ecbasis cuiusdam captivi, das älteste Tierepos des Mittclalters, herausgegeben, Strassburg, 1875. (Voigt ed.).

F. Ermini, Poeti epici latini del seculo X, 1920, pp. 159-176 (selections, 349 lines). (Ermini: Poeti).

K. STRECKer, Ecbasis cuiusdam captivi per tropologiam (in Scriptores rerum germanicarum in usum scholarum ex Monumentis Germaniae Historicis separatim editi), Hannover, 1935 (photomechanischer Nachdruck, 1956). (Strecker ed.).

\section{REVIEWS AND DISCUSSIONS OF EDITIONS}

HeIDbrefDe, Epistola ad Jac. Grimm virum excellentern de Ecbasi captivi, pubi. by C. Schmidt in Bielefelder Programm, 1841. (Heidbreede-Schmidt).

R. PeIPer in Anzeiger für deutsches Altertum 22, 1876, pp. $87 \mathrm{ff}$ - a review of the Voigt ed.

J. RATHAY in Zeitschrift für die österreichischen Gymnasien 27, 1876 - a review of the Voigt ed.

F. SEILER in Zeitschrift für deutsche Philologie 8, 1878, pp. $362 \mathrm{ff}$. (see also Anzeiger für deutsches Altertum, 4, 1878, pp. $296 \mathrm{ff}$.) - a review of the Voigt ed.

J. ZACHer, "Postille zur Rezension der Voigtschen Ausgabe durch F. Seiler," in Zeitschrift fïr deutsche Philologie 8, 1878, p. 374 f.

O. Schumann in Anzeiger für deutsches Altertum 55, 1936, pp. 121 ff. - a review of the Strecker ed.

\section{TRANSLATIONS}

G. A. Weiske, Die Flucht. Programm der lateinischen Hauptschule in Halle, 1858, pp. $13 \mathrm{ff}$.

E. Gressler, Ecbasis captivi. Die Flucht eines Gefangenen. Daj älteste Tierepos des Mittelalters. Im Versmass der Urschrift übersetzt, Dresden und Leipzig, 1910.

K. STRECKer in Anzeiger für deutsches Altertum 35, 1911, pp. 291 ff. - a review of Gressler. (Strecker-Gressler). 
H. КUSCH, Einführung in das lateinische Mittelalter 1: Dichtung, Berlin, 1957, pp. 288-325 (a translation of 11. 392-1097). Vols. II and II never appeared.

\section{GENERAL ARTICLES}

E. VoIGT, "Untersuchungen über den Ursprung der Ecbasis captivi" in Jahresbericht des Friedrichgymnasiums zu Berlin, 1874. (Voigt-Untersuchungen).

F. ZARNCKE, "Beiträge zur Ecbasis captivi" in Sitzungsberichte der sächsischen Gesellschaft der Wissenschaften 42, 1890, pp. 109 ff. (see also E. Voigt in Zeitschrift für deutsche Philologie 20, pp. 363 f).

K. STRECKER, "Ecbasisfragen" in Historische Vierteljahrschrift 29, 1934, pp. 491 ff. (Strecker: Ecbasisfragen).

K. STRECKer in W. Stammler's Die deutsche Literatur des Mittelalters: Verfasserlexikon I, 1933, pp. 484-490. (Strecker-Vflex.).

K. LANGOSCH in Merker-Stammler, Reallexikon der deutschen Literaturgeschichte, 2. Aufl., 1960. II: Mittellateinische Dichtung in Deutschland, p. 364. (Langosch-Reallex.).

K. LANGosCH in Merker-Stammler, Verfasserlexikon v, 1955, pp. 161 f. (Langosch-Vflex.).

K. ERdManN, "Konrad II. und Heinrich III. in der Ecbasis captivi," in Deutsches Archiv für Geschichte des Mittelalters 4, 2, 1940-1941, pp. 382-393.

G. VINAY, "Contributo all interpretazione della Ecbasis captivi," in Convivium 1949, pp. 234-241.

W. Ross, "Die 'Ecbasis captivi' und die Anfänge der mittelalterlichen Tierdichtung" in Germanisch-Romanische Monatsschrift N.F. Iv, 1954, pp. $266 \mathrm{ff}$.

A. MiCHEL, "Die Ecbasis cuiusdam captivi per tropologiam, ein Werk Humberts, des späteren Kardinals von Silva Candida," in Sitzungsberichte der Bayrischen Akademie der Wissenschaften, Philos.-histor. K1., 1957, 1.

P. Lehmann in Deutsches Archiv für Geschichte des Mittclalters 14, 1958, pp. 256-258 a review of Michel.

K. LANGOSCH in Historische Zeitschrift 1901, i960, pp. 195 f. - a review of Michel.

F. BRUNHölzL in Zeitschrift fïr deutsche Philologie 80, 1, 1961, pp. 100 f. - a review of Michel.

Hartmut HoffmanN, "Poppo von Trier in der Ecbasis cuiusdam captivi?" in Archiv für Kulturgeschichte 40, 1958, pp. 289-314.

H. R. JAUSs, Untersuchungen zur mittelalterlichen Tierdichtung (Beiheft 100 zur Zeitschrift für romanische Philologie, Tübingen, 1959).

E. H. ZEYDEL, "Betrachtungen über die 'Ecbasis captivi”" in Mittellateinisches Jahrbuch II, 1964.

\section{MISCELLANEOUS}

M. Wilmotte, "Un centon d'Horace au xe siècle," in Etudes horatiennes, Travaux de la Faculté de Philosophie et Lettres de l'Université de Bruxelles vII, 1937, pp. 255-265.

B. BiSCHOFF, "Elementarunterricht und probationes pennae in der ersten Hälfte des Mittelalters" in Classical and Medieval Studies in Honor of Edward Kennard Rand, ed. by L. W. Jones, New York, 1938, p. 13. 
F. Ermin, "Un imitatore d'Orazio nel medio evo," in Medio Evo Latino. Studi e richerche. University of Rome, Modena, 1938, pp. $183 \mathrm{ff}$. (Ermini-Orazio).

C. ErdmanN, "Die Entstehungszeiten des 'Waltharius' und der 'Ecbasis captivi" in Forschungen und Funde 17, 1941, $169 \mathrm{ff}$.

K. HAUCK, "Haus- und sippengebundene Literatur mittelalterlicher Adelsgeschlechter, von Adelssatiren des 11. und 12. Jahrhunderts aus erläutert," in Mitteilungen des Instituts für österreichische Geschichte, 62, 1954, pp. 137-145. 



\section{ECBASIS CVIVSDAM CAPTIVI PER TROPOLOGIAM}

Cum me respicio transactaque tempora volvo,

De multis miror, puerilis quę vehit error:

Nil cogitans sanum, tempnens consortia fratrum

Nectebar neniis, nugis quia totus in illis;

5 Tempore discendi periit cautela magistri,

Horas dictandi superavit cura vagandi.

Nam quia sic vixi, possedi nomen aselli,

Cuius raucisonum querens vitare ruditum;

Quamquam sit serum, meditabor scindere saccum,

$10 \mathrm{Vt}$ iuga torporis pellant rudimenta laboris,

Incipiens versus, quos rarus denegat usus.

Pellitur his somnus, frenatur potus et ęsus,

Sepe caput scabitur, vivus conroditur unguis

Tunditur atque stilus grandi meditamine strictus.

15 Talia qui versat, pigritandi iura recusat,

Hic sua devitat, dum pulchra poemata cantat.

Sunt etenim quidam, si me depingere quiddam

Audierint falsi, certabunt legibus ęqui

Ac mea transmisso transfigent carmina telo.

20 Consuescunt multi, quam qui sint carmine docti,

Longos accentus per miros vertere flexus.

Nam pede composito certans insistere metro,

Sillabicos cursus cum sim discernere tardus,

Tempora temporibus eque coniungere cecus,

25 Rectius hoc faciam, linguam si pressero blesam.

Scribitur et legitur, priscorum carmine scitur,

Per campos, silvas, fluvios properare Camenas,

Quo pede pervolitent vel quę sibi carmina dictent;

Exitus et reditus quarum per maxima cautus 


\section{THE ESCAPE OF A CERTAIN CAPTIVE}

Told in a figurative manner

When I look back on myself and contemplate the times that have passed, I wonder at many things which childish error brings:

Planning nothing sensible, scorning the company of my brethren, I was involved in puerile follies because I was wholly given to such trifles; During the time of learning the wise solicitude of the teacher was wasted, And my interest in giving my imagination free rein defeated the hours of Because I lived thus I bore the name of a little ass [study. Whose hoarse-voiced braying I now seek to avoid; Although it is late, I plan to rend the sack-cloth

10 So that (with) my first beginnings of work (I) may throw aside the yoke of And I may start my verses which infrequent practice frustrates. [laziness Sleep is driven away by these, drink and food are checked.

Often my head is being scratched and my fingernail chewed, And the stylus thumped as I am consumed by deep meditation. Who ponders such tasks rejects the habit of laziness, He gets around his own laziness by composing lovely poetry. Certain people, if they hear me depicting something Fictitious, will oppose with the laws of truth And transfix my songs with a piercing weapon.

20 Many, especially those learned in poetry, are accustomed To carry long melodies through artful variations.

So in striving to adhere to meter composed by foot, Since I was late in learning to distinguish the course of syllables, And blind in properly linking one tense with another, I would do this better by restraining my stammering tongue. It is written and read and known through the poetry of the ancients How the muses romp through the fields, woods and streams, And on what foot they flit and what songs they sing to them (the Their extremely careful going and coming [ancients). 
30 Commonet insulsum, ne fimo polluat aurum, Increpat indoctum de cęlis scribere versum, Arguit invalidum per fortia tendere gressum. Territus hisce minis meditor desistere ceptis. Rerum gestarum viguit mos tempore patrum,

35 Nullus ut auderet conscribere, quę sibi vellet, $\mathrm{Ni}$ prius auditor certus foret ille notator

Disceret aut visu, quid commemorabile scriptu;

Pagina sic certa valuit sub testibus acta.

$\mathrm{Hec}$ ego dissolvam, raram si pono fabellam,

40 Confiteor culpam: mendosam profero cartam.

Sunt tamen utilia quę multa notantur in illa;

Si recitas totam, panis mercabere tortam.

Denique non prodest, sed obest, ut sepe probatum est, Vna re quemcumque suam consumere curam;

45 Sed varias artes ediscant quique scolares, Sit scola discendi, succedat cura docendi.

Sub specie certi nascetur questio scripti, Ad quid cepissem seu talia cur replicassem; Ad quod solvendum scribetur quid referendum:

50 Namque die quadam consueto more sedebam, Inspexi quosdam generalem sumere curam, Grandia triticeum cumulare per horrea fructum; Illos post segetes dilectas visere vites, Illos collectis sollertes esse vehendis

55 Non solis monachis, qui servant mistica legis, Immo peregrinis, mendicis atque pupillis;

Per sibi commissas reliquos discurrere curas, Me vero vacuo, claustrali carcere septo. Acrem mordebant animum monimenta priorum,

60 Flebilibusque vagas contingens vocibus auras Męsti fel cordis reparabam more medentis Partim cauterio, partim medicamine puro, Imperiosa prius deflens solamina tulta; Dicere non poteram, tacita quod mente coquebam.

65 Ceu truncus sterilis lignis ęquabar adustis Ac misero vitulo sudibus quam sepe ligato: 
30 Warn the foolish person not to pollute gold with filth,

Caution the unschooled against writing verse about the heavens,

And warn the weak about taking difficult steps.

Frightened by these warnings, I think of refraining from my undertaking.

The custom prevailed in the time of our fathers

That no one dared to describe any deeds he might wish,

Unless the writer himself had definitely heard

Or had been an eye-witness to what was to be set down in writing.

Thus the page vouched, under witness, for the certainty of the event.

If I offer a mere fable, I will undo that practice.

40 I confess my guilt: I present a fictitious work.

Nevertheless there are many useful things to be recorded in it;

If you recite it as a whole, you will earn a twisted loaf of bread.

Finally it is not advantageous, but disadvantageous, as has often been

For all to devote their care to the same matter. proved,

Rather should each scholar master different skills.

Let school be for the learner and the concern for teaching follow.

In view of what is certain let questions be asked about what is written, Why I have undertaken such things and pondered them?

Let there be written what must be reported, so that it can be judged.

50 Now on a certain day I was sitting in my accustomed manner.

I saw some taking general care

To gather the fruit of the wheat in large barns, Others, after the grain, to tend to the choice grapes,

Others, to show skill in transporting what had been collected,

Not for the monks alone who serve the obscurities of canon law,

No, also for the pilgrims, beggars and orphans.

The others were all pursuing the tasks assigned to them,

While I alone was idle, shut up in my cloistered prison.

The memory of former times gnawed at my bitter heart,

60 And defiling the fleeting breezes with mournful sounds,

I restored the bile of my sad feelings in the manner of a physician,

Partly with a branding iron, partly with plain medicine,

Mourning the powerful comforts of yore that have been taken away.

I could not utter what I was cooking in my unspoken thoughts.

Like a sterile trunk, I resembled charred wood

And an unhappy calf bound to stakes like a fence. 
Illi consimilis patrum frenatus habenis, Cuius et historiam non simplo stamine texam.

Post octingentos domini, post ter quater annos,

70 Aprili mense, pasche bis septima luna; Sic vixit vitulus, Vosaginis partibus altus, $\mathrm{Vt}$ legitur scriptis in precedentibus istis, Annuus existens redeuntis tempore veris. Pastores ovium multi tardique subulci

75 Cum grege fetoso satagunt exire gregatim, Custodesque boum nec non servator ęquorum. Cura pervigili dum lustrant pascua campi, Clauditur ille domi lugens sibi colla ligari; Gaudia nulla foris, intus pressura doloris, 80 Et quod plus istis, absunt consorcia matris. Triste sat ingemuit, cordis suspiria traxit, Erigit ad celum facies atque invocat Iesum, Conclamat lacrimis binis pariterque vicenis, $\mathrm{Vt}$ custos stabuli solvat sibi vincula colli, 85 Vbere de matris quo gustet gaudia lactis. Hęc duo suspirat, quę per contraria tornat,

Cumque negatur iter, distentum tollitur uber, Nititur arte fuge, quo possit currere late; Masticat, lingit, tandem sic lora resolvit, 90 Prosilit et plaudit, tenero terram pede tundit, Mugitum reprimit, vernantia prata revisit.

Concessa est pecori libertas laxior illi, Scandere seu levo malit seu tramite dextro, Sumere seu requiem seu continuare laborem.

95 Cursitat ille strepens, paribus concurrere gaudens. Hec cum fastidit, silve tutamina querit, Huius in occursum forstrarius elicit ymnum, Moris ut est monachis longo de calle reversis: ,Sit salvus, Christe, servus, qui mittitur ad me, 100 Te fisus domino letetur semet in ipso. Hic habet hospicium noctis sub pace quietum, Ast nostras post cras sacrabit sanguine mensas; 
Tethered like it with the thongs of the fathers,

I shall weave its story into a woof that is not without complexity.

After eight hundred and thrice four years of our Lord,

70 In the month of April, occurred an Easter full moon;

There lived in this manner a calf, reared in the region of the Vosges,

As can be read in what has been written above,

Now a year old as springtime returned.

Many sheep-herders and dull-witted swine-herds

Are busily going forth flockwise with their prolific herds,

Also the herders of the cattle and the groom of the horses.

While they traverse the pastures of the field with watchful care,

The calf is shut in at home, grieving that his neck is tied.

There is no joy outdoors, within there is pressure of grief.

80 And what is even worse, the companionship of his mother is missing.

Sadly he lamented a deal and drew heart-felt sighs.

He lifts his face toward heaven and invokes Jesus,

Calls with tears twofold and even twentyfold

For the stableman to take his chains from his neck,

So that he may enjoy the pleasures of milk from his mother's breast.

For these things he yearns with sighs and then turns them into the [opposite (into activity),

For since a way is denied and the full udder is taken away,

He strives (through the device of flight) for a chance to run far away;

He champs, licks, and at last releases the thongs in this manner,

90 Leaps forward with exultation and stamps the earth with his frail hoof,

Suppressing his lowing, and seeks the greening meadows again.

Greater freedom is left to that animal,

Whether he prefers to scamper on the left path or along the right,

Whether he would seek rest or continue his toil.

He romps noisily, rejoicing in a run with his equals.

When he tires of that, he seeks the shelter of the forest, And meeting him, the forester (wolf) utters a song of joy, As is customary for monks returning from a long journey.

"May the servant, O Christ, be blessed who is sent to me.

100 As he trusts in You, may he rejoice in the Lord Himself.

Here he will have restful hospitality under the peace of night,

But later, tomorrow, he shall consecrate our tables with blood. 
Qui peccare valet, valet et succumbere pęne'. Moxque cavernosos iussus penetrare recessus

105 Ducitur ad lustra multo fetore referta.

Tunc lupus, ad libitum sese saciare gavisus,

Extulit hunc versum cuncta pietate perustum:

,Dicito, quid venias, qua nos ratione revisas?

Tu mihi nunc, sodes, optatus diceris hospes.

110 Laudes dic superis, silve novus incola surgis,

$\mathrm{Tu}$ recreare venis tenuatum corpus ab escis.

Tercius est mensis, quod frustror nectare carnis,

$\mathrm{Nec}$ biberam cratum pecudis de sanguine tinctum.

Cum prorepserunt primis animalia terris,

115 Mutum et pingue pecus nobis fabricaverat usus.

Ordinis est virtus, placetur sanguine divus'.

Incipit hec vitulus, singultim pauca loquutus,

Infans namque pudor prohibebat plura profari:

VITVLVS

SECVM.

120 Peccatis noctem, quin fraudibus obice nubem.

Si redeam gratis, grates exolvero divis,

His et pro meritis dabitur caper omnibus aris'.

RESPONSIO ,Jam dudum ausculto, sed dicere plura retardo.

PVBLICA.

Inberbis iuvenis, Tullensis discolus urbis,

125 Peccatum fateor, iuvenilis me gravat error.

Hoc reus existo, nolens parere magistro.

Sensu, quo sensi, dissolvi vincula colli,

Huncce locum petii, mortem mihi forte paravi;

Hanc noxam dona; reliquam si fecero, macta.

130 Non facias longum, magnorum maxime regum,

Pacis palma detur, donec cras missa canatur.

Heinrici placitis cepi moderamina pacis.

Vt sunt scripta patrum, ploret transgressio fratrum:

In levibus modicus, per fortia fortior ictus".

135 Tum dominus cavee ,misere cupis` inquid ,abire;

Vt vult ipse deus, optatum sit tibi tempus.

Illud ad hec iubeo: mentem servare memento, 
Whoever is capable of sinning can also succumb to punishment," And presently, ordered to go to a cavern-like retreat, The calf is led to a nook full of foul odor.

Then the wolf, rejoicing that he can satiate himself at will, Uttered this verse glowing with all dutiful kindness (i.e., hypocrisy):

"Tell me, why do you come, for what reason do you visit us? If you please, you will now be called a desirable guest by us.

110 Speak praises to the gods, you appear as a new denizen of the woods, You come to restore by food a body weakened (by fasting).

It is the third month that I am cheated of the nectar of meat, Nor have I drunk a beaker tinged with the blood of a beast. When the animals first crept forth from the young earth, Need fashioned for us mute and fat cattle.

It is the virtue of heavenly order, the divinity is placated by blood." The calf begins the following, speaking few words amid sobs, Childish shyness forbade him to say more:

(Calf to himself) "Jupiter, thou who givest and takest away great labors,

120 Spread night over my sins, and a cloud over my deceit.

If I return unscathed, I will give thanks to the gods,

And a goat will be offered for such services at all altars."

(His audible reply) "I have been listening for a long time but hesitate to A beardless youth, a derelict of the city of Toul. [say much, I confess my sin; youthful error burdens me.

In this I am a wrongdoer, being unwilling to obey my teacher.

With such sense as I employed, I dissolved the chains from my neck And sought this spot, perhaps preparing my own death;

Pardon me this wrong. If I commit another, slay me.

130 Do not delay long, greatest of great kings.

Let the palm of peace be granted until mass is sung tomorrow.

Through the decrees of Henry I have received the guidance of peace [(safe conduct).

As the writings of the fathers say, let the sins of the brothers show

[contrition:

For trivial wrongs a moderate blow, for more serious ones a stronger one." Then the master of the cave said: "Wretch, you want to leave, As God Himself wishes, may you have the desired respite.

This I order for such purpose: Remember to keep your wits, 
Corpore stes leto, concedens oscula caro'.

140 ,Pellito namque famem, pransurus scandito sedem, $\mathrm{Nec}$ poscar vario multum diversa palato,

Quęcumque inmundis fervent allata popinis, Que, nisi divitibus, nequeunt contingere mensis, Sed pocius foliis parcus vescaris acerbis.

145 In gravitate cibi crescit discordia morbi. Sunt mihi lactuce, radices, semina silve.

Sanius est multo cerebrum, qui potat acetum:

Ex vitio cerebri frenesis furiosa movetur.

Stringeris melius, si fluxa cucurrerit alvus.

150 Cursitat ericius, pomis revehatur onustus, Luter piscator properat pro piscibus emptor.

Ne plores nimium, sed pangito carmina regum.

Poscis inane deos; inferni iure sepultus

Victima Plutonis sterneris nil miserentis;

155 Dum licet, in rebus iucundis vive beatus'.

Ille cubans gaudet, prelambens omne, quod affert, Quid durum, quid molle foret; quid lene, quid horrens, Quid calidum, gelidum; dominorum, quid famulorum, Continuansque dapes succinctus cursitat hospes,

160 Fungitur officiis nec non verniliter ipsis, Multaque de magna creverunt fragmina cena, Quę procul instructis inculcat habenda canistris. Jam nox per medium gaudebat currere cęlum, Cum subito missi properant, qui munera portant:

165 Inter quę rombus, cum multo milite barbus, Flexilis et congrus, cum quis mugil generosus, Gobio, sepiole, lolligo cum capitone, Cancri, mulli, trutta, cavedonus, hicherus, allec, Affuit et salmo nutritus flumine Hreno,

170 Nec aberat donis piscosi grex Rabadonis, Quod fundoque Mose capitur piscis genus omne; 
Be happy and kiss me, your dear friend."

(Calf to wolf) "Why do you feign to be a friend and greet me with

[amiable deceit?"

140 (Wolf) "Banish your hunger and sit on the chair to eat,

And do not demand too many different foods for a palate that craves

[variety,

Such that are steaming as they are brought from untidy kitchens

And cannot touch tables, except rich ones.

But rather, feed on bitter herbs sparingly.

In the heaviness of food the discord of illness increases.

I have lettuce, radishes, seeds of the forest.

The brain of him is much more sane who drinks sour drink:

From the fault of the brain raging madness develops.

You will fare better if your belly has passed along food that it not

150 The hedgehog runs and comes back laden with apples, [sluggish.

The otter, the fisherman, hastens, the buyer of fish.

Do not lament too much, but strike up the paeans of the kings (Conrad

[and Henry).

You entreat the gods in vain; buried according to the laws of the Lower You lie prone, a victim of unpitying Pluto.

[World,

While it is permitted, live happy in a joyful state."

With joy the calf reclines, licking everything that is brought,

What is hard, what is soft, what is mild, what is coarse,

What is hot, what is cold, what is for masters, what for servants,

And continuing the feast, the girded host hastens,

160 Carrying out his duties, but not in the fashion of a domestic, And many left-overs were accumulated from the great banquet, Which he stores, pressed into baskets that are set aside.

Already night was rejoicing in passing the center of the sky, When suddenly the messengers approach and bring gifts, Among which are the turbot, the barbel with quite a following,

And the slippery eel, and with them the noble lamprey,

The gudgeon, the cuttle-fish, the bream with the tadpole,

The crab, red mullet, the trout, chub, sturgeon, herring,

And there was present also the salmon grown in the Rhine river,

170 Nor were there missing from the gifts the schools of the Rabado rich in And all the kinds that are caught in the bed of the Meuse.

[fish, 
Prefert se cẹto spinx captus in mane Petroso,

173 Squamigeros cetus punctis pellebat acutus.

175 Detulit hęc luter, carus placidusque minister.

176 Optulit ericius, spinoso vellere sutus,

174 Rugosum piper ac costus lentumque papaver, Porros et caules, rafanos quoque viribus acres, Molles castaneas, domnis cenantibus aptas, His cydonia sunt, crustumia denique mixta.

180 His ita susceptis redibetur gratia missis.

Considunt pariter; tum sic ait ipse magister:

,Septimus octavo propior iam preterit annus, Ex quo cum pomis, cum piscibus urbe petitis Mensas ornavi, convivas ipse refeci;

185 Sic vixi monachus, claustralia iura secutus, Omnia distractis coemens obsonia gazis.

Gratia sit vobis, quod sic mihi subpeditastis.

Afficior senio, vobis mea cuncta relinquo,

Ericio rupem, lutro pro piscibus amnem:

190 Protinus arrident, collum faciemque remulcent.

Vt me conspiciunt, confestim talia dicunt:

,Mirum fit nobis: quid hic castellat in antris?

,Dum sprevit stabulum, nostrum divertit ad antrum

Et manet insopilis, nostris addictus habenis.

195 Jure fruor torto, quia vivit tempore tanto;

Me tenet huius amor, legirupis ipse vocabor,

Mane sed officium faciat mihi more suorum,

Sanguinis ex calice roret siccamina lingue;

Proluet hic potus spurcamina pectoris huius.

200 Hic fossa est ingens, hinc rupes maxima pendens:

Mergitur in fluvium, mergens educ fugitivum,

Si scandit rupem, prosternes hunc ab eadem;

Ne nos implanet, constans tua cautio curet.

Tunc mihi carus eris, custos si providus adsis'.

205 ,Hoc sequar, hoc fixo conceptum corde tenebo'.

Armiger ericius, clavata sindone tectus,

Nec studio cithare nec Muse deditus ullę, 
The sphinx, fished in the river Petrosus, thinks it is better than the crowd.

173 It was sharp and drove away the scaly throngs with its points.

175 These things the otter brought, the beloved and gentle servant.

176 The hedgehog, clad in a thorny fleece, brought

174 Curled pepper and mint, and sluggish poppy,

Leek and cabbage and horse-radishes sharp in their strength,

Soft chestnuts suitable for dining lords,

And mixed with them quinces, and finally Crustumean pears.

180 When those had been received, thanks were given to the messengers.

They sit down together; then the master himself speaks thus:

"The seventh year, nearer to the eighth, is now passing

That with apples and fish acquired in the city

I've adorned my tables and in person refreshed my companions.

Thus I lived as a monk, following the custom of the convent,

Buying up all victuals with wealth of which I deprived myself.

Thanks be to you that you supported me in all this.

I am burdened by old age, I leave all my possessions to you,

To the hedgehog the cliff (castle), to the otter the stream for fishing."

190 Forthwith they smile and bow neck and head.

When they see me, straightway they speak as follows:

"It surprises us: Why is he (the calf) housed in the cave?"

(Wolf to otter) "Since he spurned the stable, he turns to our cave

And remains sleepless, under the control of our reins.

I enjoy a perverse right because he has lived here for so long a time.

The love of him holds me; I will be called a law-breaker,

But tomorrow let him fulfill his duty to me in the manner of his kind,

Then from the chalice of blood let him dampen the dryness of my tongue.

Let this drink wash away the impurities from my breast.

200 Here is a mighty ditch, from here a huge cliff overhangs:

If he dives into the stream, dive in and bring back the fugitive,

If he climbs the cliff, throw him down from it;

That he may not deceive us, let that be your constant care.

You will be dear to me if you are present as a cautious guard."

(Otter) "This I will follow, this I will keep preserved in my steadfast

[heart."

The arms-bearing hedgehog, covered with a nail-studded garment And not given to the study of the cithara, nor to any muse, [(pfeller), 
Fit capitale lupi, citharizans fortia belli, Romam, res letas et prospera queque retexens,

210 Mille triumphorum memorans ex ordine pompas Ductaque per mediam spoliorum fercula Romam Omnibus ex terris, quas undique continet orbis. Occupat ipse aditum, ne fas sit vadere captum, $\mathrm{Vt}$ canis a corio numquam absterrebitur uncto.

215 Nam vitulum luter reficit, cum belua stertit, Dulcia depromit, super hęc ortamina fudit:

,Pellito nunc vino, nunc curam solvito somno, Forciaque adversis opponito pectora rebus:

Grata superveniet, quę non sperabitur, hora'.

220 Ad mensam vituli legitur Reparatio lapsi.

Cum fuit expleta, collatio dicitur ista:

,Conditor ipse poli prudens fabricator et arvi, Qui mestos refoves, vinctis solamina prebes, In te confido, clausum me solve baratro,

$225 \mathrm{Vt}$ te collaudem videam geminumque parentem'. Hec lacrimans poscit, quin completoria dixit. Post noctem mediam, quando sunt somnia vera, Spelunce dominus, de visis obstupefactus, Quod strato vidit, enarrans fratribus inquit:

230 ,Dicite consocii, quo tendat visio somni. Bruchi cum vespa, cynifes, cenomia multa Me circumvolitabant, dente sed asperitabant, Bini crabrones certabant stringere fauces, Quod mihi nulla salus mansit nec vivida virtus.

235 Adfuit his vitulus celso cum carmine mixtus, Quin etiam vulpes geminabat in ethera voces, Ac si docta manus monstret modulamina cantus'. ,Hostibus ista tuis! Nihil est, quod tu verearis; Credas consilio: viso salvabere somno,

240 Scilicet ut vitulum patiaris abire tenellum; Quod si postponis, soli tibi damna parabis. In grege muscarum noscas spelea ferarum, Quę te dilanient et toto corpore scindent; 
Becomes the pillow of the wolf, strumming songs of bold deeds of war, Of Rome, of happy events, and recounting all kinds of good fortune,

210 Recalling in due order the splendors of a thousand triumphs, And the floats bearing spoils through the heart of Rome From all lands which the world encompasses on every side.

Personally he occupies the entrance, so that the captive could not escape, As a dog will never be driven away from greased leather.

Now the otter refreshes the calf while the beast (the wolf) snores, The otter takes down sweets and in addition poured forth these exhor-

[tations:

"Now drive away your care with wine, now dissolve it with sleep And oppose adversity with a stout heart.

A welcome hour, not expected, will come."

220 At the table of the calf the Rehabilitation of the Sinner is read.

When it was finished, this prayer is spoken:

"Thou creator of the Heavens and wise Maker of the fields, Who restorest the downcast and offerest solace to those in bonds, In Thee I trust, release me shut up in the abyss, That I may praise Thee and see my two parents." This he asks with weeping and then spoke the concluding prayer.

After the middle of the night, when dreams are true, The master of the cave, startled by dreams and visions Which he had seen when on his couch, related them to his brethren

230 "Tell me, comrades, what my dream-vision portends. [and said: Insects with wasps, stinging gnats, many dog-flies Flitted about me and lacerated me with their teeth, And two hornets vied in strangling my throat, So that no safety remained for me nor energy.

The calf was present among these, in the midst of a noble song, Nay, even the fox raised his voice aloft into the ether, As though a learned hand (cantor) were teaching the melody of the chant." (Otter) "These horrors to your foes! There is nothing you should fear; Trust my advice, you will be saved from the dream-vision

240 Provided you allow the tender calf to go free;

But if you put if off you will bring destruction upon yourself alone. In the swarm of flies you may recognize the caves of the wild beasts Which will tear you to pieces and cut up your whole body; 
Nam stimuli vespe sunt vires mortis acerbe.

245 Binos crabrones ambos cognosce parentes,

Qui natum deflent, fauces tibi stipite figent.

In iubilo vulpis proprii cape signa meroris.

Infelix vitulus, non grata compede vinctus,

Exiet ad campum, bellum cum noverit ortum.

250 Quid dabis ergo boni? - sic stat sententia somni.“

LVPVS.

,Hei mihi! quid faciam vel qualia verba retexam?

Quę bona distribuam? quę mundiburdia queram?

Poscis pro vitulo, minitaris pro perituro;

Si daret Heinricus, vobis percarus amicus,

255 Porcos quingentos, vitulos totidem saginatos,

Non foret inpune, quod sparsit fragmine cęnę

Vve dulcorem, solitum 〈mihi〉 ferre soporem.

Cur perit incassum tanto sudore paratum?

Quod foris excessit, nobis nullatenus hesit,

260 Sed post ingressum sit nobis discutiendum.

Instauret quadruplo sumptus tultos mihi simplo.

Mane canam psalmos, si tardat sacra sacerdos.'

Archicapellanus, camerarius et cocus almus,

Iudex consilii, quin iudex illius antri

265 Extitit ericius, perplexo vellere sutus,

Namque super cunctos nanus fuit iste sacerdos;

Indumenta novis texebat plumea telis.

LVPVS ERICIO. ,Post horam sextam capto mox tollito vitam;

Quod petiit feci, nam vix promissa replevi.

270 Portio nulla detur, sed ne per frusta secetur,

Dispice, neve cocoque foco tostetur ab ullo.

Hec caro nectarea festivum sit mihi pasca;

Hanc tege pigmentis redolentibus et sale pauco.

Esca multiplici ne fallas federa disci,

275 Per varios gustus hec fercula nostra regamus.

Lignum pomiferum si roras iusse fabarum,

Radix continuo siccabitur huius ab imo,

Marcescet sucus, vanescet in arbore fructus. 
Now the stings of the wasp are the powers of bitter death.

In the two hornets recognize the two parents

Who mourn their child and will pierce your throat with a stake.

In the joy of the fox find the signs of your own grief.

The unhappy calf, bound with an unwelcome fetter,

Will go forth free to the field when he knows that war (against us) has

[arisen.

250 What good offering will you bring? - That is the meaning of the dream." (Wolf) "Woe is me! What shall I do and what words shall I repeat?

What goods shall I distribute, what assistance shall I seek?

You beg on behalf of the calf, you threaten on behalf of one about to If Henry, your very dear friend, should give

Five hundred swine and the same number of fatted calves,

[perish;

Yet the calf would not be subject to punishment because he sprinkled

[among the crumbs of the meal

The sweetness of the grape, to bring me wonted sleep.

Why does that vanish in vain which I prepared with so much sweat?

That he escaped into the open is no concern of ours,

260 But he should be cut to pieces by us now that he has entered here.

Let him repay fourfold the costs taken from me.

Tomorrow I shall sing psalms if the priest delays the rites."

As archchancellor, chamberlain, and nourishing cook,

As judge of the council, nay as judge of the cave itself

The hedgehog served, clad in a thick coat,

And their priest over all was the dwarf;

He had woven downy garments of new woofs.

(Wolf to hedgehog) "Soon after the sixth hour take the captive's life;

What he has asked, I did, and carried out what I had scarcely promised.

270 Let no portion of him be given to anyone and let him not be cut to pieces, And see to it that he shall not be roasted by any cook at the hearth.

This nectar-like meat shall be a festive Easter lamb to me;

Season it with fragrant spices and a little salt.

Lest you violate the table of the Covenant by elaborate food,

Let us season these our courses with many condiments.

If you moisten the wood of a fruit tree with the broth of beans,

Its root will immediately be dried from the bottom up,

The sap will evaporate and the fruit on the tree vanish. 
Tussis sicca fabis asino sit gloria dulcis,

280 Sit vox scabra fabe porcello gloria palme.

Hisce fabis virtus viciata est corporis huius,

$\mathrm{Nec}$ possum teneram telluri affligere plantam;

Sic periit, solitum dum non habet arida pastum,

(Sint hec barbaricis mandenda legumina Francis),

285 Sic erit nullus honus: potior mihi pristinus est mos,

Hunc morem repetam, 〈nunc〉 ad mea prisca recurram.

Devoro nunc carnem, preclaram persono vocem,

Sunt vituli carnes pociores quam gobiones,

Inde traham sucum crassoque humore salutem,

290 Fit rubor in facie, pallor tabescit in ore,

Blandus corde sapor, flagrans odor, apta voluptas;

Omnia percurram, quo limum pectore pellam.

LVTER.

,Ah, perversa vigent, legalia iura fatiscunt."

LVPVS.

,Ergo sales vestri veterani sint sine dente.

295 Non patiar, teneas veteres ut me duce nugas.

LVTER.

,Si sapis, hec tacito consumes verba palato.

Vtere sorte tua, doctus pietate paterna.

Annis iam septem vitam deducis agrestem;

Omne genus carnis vitabant intima ventris,

300 Cunctis delitiis preponens munera piscis,

Sepe tue mense iungens consortia trutte;

Nunc comedes vitulum, sanctum spernens monachatum.

Non preter solitum cogor dissolvere luctum?

Tot mala succedent, quę te per tristia vertent.

305 Nomine tu monachus, sed dextro limite tortus

Crimina pertractas, sanctum subvertere certas.

Adversus mitem piceum postpone furorem.

Evigilet monachus pergrandi compede vinctus,

Regula queque docet, verbis simul actibus ornet:

310 Nil fore quod proprium, commune sed omnibus unum,

Quod sibi non fieri, fratri non irroget ulli. 
Let his hacking bean-cough be a source of sweet glory to the ass,

280 And let its coarse bean-voice be like palm-leafed glory to the porker.

The strength of this my body has been weakened by such beans,

And I cannot cast down the tender plant to the earth;

Thus it has perished because in its dryness it does not have its wonted

[nourishment,

(Let these vegetables be commended to the barbarian Franks),

Thus you will have no honor: to me the old custom is preferable,

And this I will follow and return to my old ways.

If I now devour meat, I shall shout the glorious word,

The meat of a calf is preferable to gudgeons,

From it I will derive juice, and health from its strong fluids,

290 Ruddiness will appear in my face and paleness will vanish from my [countenance,

Taste pleasing to the heart, pleasant savor, fitting delight;

I shall try everything to drive the impurities from my breast."

(Otter) "Ah, perversity flourishes, law and order are exhausted."

(Wolf) "Then let your old wits be without a bite.

I shall not suffer you to entertain ancient nonsense with me as your

[guide."

(Otter) "If you are wise, you will swallow such words with a silent mouth.

Taught by paternal love, take advantage of your lot.

For seven years now you lead the life of a peasant;

The inside of your stomach has avoided every kind of meat,

300 Preferring the blessing of fish to all other delights,

Often having added the company of the trout to your table;

You will now devour the calf, spurning the holy monastic fare.

Must I unfetter grief, in keeping with my wont?

So many evils will come to you which will turn you to sadness.

In name you are a monk, but turned from the right course

You deal in criminal things and strive to upset what is holy.

Set behind you your pitch-black rage against this gentle creature.

Let the monk, bound with a huge fetter, be watchful

And grace with words and actions whatever the rule teaches:

310 That nothing should be private property, but one and common to all, And let him not inflict upon any brother what he would not have done to

[himself. 
Sic quia non vivis, predonis lege peribis,

Judicio canonum morieris morte latronum, Hec luter cautus dicenda tacenda locutus.

LVPVS.

LVTER.

LVPVS.

LVTER.

315 ,Hec illi narres, qui surdas possidet aures, Nam caude vituli iungetur lumbus aselli;

Sic natura parens iussit discurrere soles." ,De lingua monachi volitet discrecio verbi. ,Si tibi sum cure, frenos imponito lingue." 320 ,Frustratur multum, piceat qui vas adaquatum; Sincerum nisi vas, quodcumque infundis acescit." Postera lux oritur, multo gratissima fertur. Cum faciem noctis pepulissent lumina solis, Corniger armenti perlustrat ovilia vici,

325 Singula qui revocat, presentia quęque regirat, De sibi commissis aspectat ne pereat quis. Mugit vacca loquax, quin taurus cornibus audax, Perdita demonstrant, natum per singula lustrant.

Ast Vosagina canis, lustrosis conscia silvis,

330 Venerat ad medium, certum dictura relatum:

,Estimo, quod vobis referentur gaudia mestis.

In Genesi legitur, Esau cum gesta feruntur, Ille sagitta doctus erat gravidaque faretra, Portabat cornu, fuerat quin doctus in arcu,

335 Capsidile suo gestabat in inguine dextro; Hic me nutrivit, per rara latibula duxit, Post mortem domini vobis mendica remansi. Visis consternor, auditis corde retundor: Juxta est speleum, multo predamine plenum;

340 Sole sub occiduo, latrans prope iam pede fesso, Audieram strepitum, certans comprendere melum; Reddetur stabulo, si forsan queritur antro.

Suscipitur sermo, quem dixit barbarus hospes, Et predocta canis ceu fertur odora canum vis, 345 Non preter cetum properans pretendere gressum, 
Because you do not live thus, you will perish in the custom of the thief [(as thieves are wont to do),

And by canon law you will die the death of highwaymen."

Such things, to be said or left unsaid, the clever otter spoke.

(Wolf) "Tell these things to one who has deaf ears,

For the loins of an ass will be joined to the tail of the calf:

Thus Mother Nature has bid us spend our days."

(Otter) "Discreetness of word should wing from the tongue of a monk."

(Wolf) "If I am dear to you, put a curb on your tongue."

320 (Otter) "He has an idle task who pitches a vat that is full of water:

Unless the vat is clean, what you pour in will turn sour."

Then daylight rises and comes most welcome.

When the light of the sun had driven away the face of the night,

The horn-bearer of the cattle (steer) explores the stalls of the village,

Calls them singly and marshals all those present,

Looks after those entrusted to him, lest any be lost.

The talkative cow lows, also the bull, daring with his horns,

They show their loss and conduct a search for their son among the

[various animals.

But the dog of the Vosges, familiar with the cavernous forests rich in game,

330 Had come into their midst and uttered this reliable report:

"I judge that joyful news will be reported to you sad folk.

In Genesis we read, where the deeds of Esau are told,

He was skilled with the arrow and with the heavy quiver,

He bore a horn and was clever with the bow,

And he wore the hunter's pouch at his right flank;

He gave me food and led me through rare coverts,

After my master's death I remained as a beggar with all of you.

I am alarmed by what I see, and my heart is dejected by what I hear.

Nearby is a cave full of much booty;

340 Under the setting sun, barking nearby, and with tired feet,

I heard a noise as I strove to catch the badger;

If perchance he (the calf) is sought (found) in the cave, he will be returned

[to the stable."

This speech is greeted which the barbarous guest spoke,

And the well-trained dog, in accord with the canine power of scent,

Hastened to keep her step ahead, but not to outdistance the crowd, 
Donec pervenit, quo se conducere vovit.

Tunc equitum turme certant peditumque caterve,

He numero plures, virtute et honore minores,

Indocti, stolidi, simul impugnare parati.

350 Viribus editior, collecto tum grege maior,

Irritat, mulcet taurus, mugitibus implet;

Fit sonus in terris, quasi totus corruat orbis.

Exilit ille lupus, somno vinoque sepultus, Convocat armigeros pugnandi iure remotos,

355 Sperat belligeros solo torpore peritos;

Arcem conscendit, hostes quo cernere possit;

Visis expavit, reparatus viribus infit:

,O famuli fortes, animosas cernite gentes;

Vnus eis animus, quamquam non unica virtus,

360 Perdere nos gliscunt ac morti tradere querunt;

Quid datis auxilii rabiose obsistere genti?

Non pugnant manibus, non arcus tenditur ullus,

Missile non iacitur, nec funda saxa rotantur,

Non sunt pennigeri pugnaces insidiosi;

365 Nam neque calce lupus neque quenquam dente petit bos;

Absit solus aper et corniger utique cervus,

His cornu bellum cum dentis acumine sevum.

Insistunt antro, non decidet ariete crebro,

Non patet ascensus, nec scandit ridiculus mus.

370 Sed vereor vulpem solidum turbare bitumen;

Si non sola potest, plures sibi iungere gaudet, Ad me perdendum vigilavit cura suorum, Prevalet, in quantum cumulaverit ipsa tumultum;

Si desunt vires, regnabunt undique fraudes.

375 Mortua sit vulpi versucia decipiendi!"

Namque duo famuli, nullo terrore subacti, 
Until she reached the spot to which she promised she would lead them. Then a troupe of cavalry and a company of infantry join in battle, The latter stronger in numbers but inferior in valor and distinction, Unschooled, clumsy, at the same time ready to attack.

350 The bull, eminent in strength and larger than the others who were [gathered there, Arouses them, flatters them, and fills (the air) with his bellowing; A commotion arises on the ground as if the whole earth were collapsing.

The wolf leaps up, buried in sleep and wine, And calls together his bearers of arms, strangers to the rules of fighting. He hopes that those skilled only in sluggishness will now become fighters: He climbs the citadel, where he can see the enemy;

He shuddered at what he saw, then with strength restored he says:

"O brave followers, see the spirited soldiery,

Their spirit is one, although their valor is not,

360 They burn ever more to destroy us and seek to hand us over to death;

What help will you offer in opposing the rabid warriors?

They do not fight with hands, and no bow is stretched, No missile is thrown, nor are rocks hurled from a sling.

The fighters plotting treachery are not wing-bearing (do not fight at long [range);

And the wolf does not fight with his heel, nor does the bull attack anyone [with his tooth;

Let only the boar stay away and especially the horn-bearing stag,

To them the horn, together with the sharpness of the tooth, is the terrible [means of warfare. Although they stand in front of the cave (castle?), it will not collapse [before the frequent blows of the ram, The ascent is not open and no ridiculous mouse can scale the height.

370 But I fear that the fox will unsettle the firm tar.

If he cannot do it alone, he will take pleasure in enlisting more in his cause, The care of his friends has been watchful for destroying me, He is strong in seeing how great a tumult he can arouse. If his strength fails, his deceit will prevail everywhere.

Let the cunning of deception be dead for the fox."

Now the two companions, bowed by no terror, 
Libera respondent dicto talique cohercent:

,Non simus iniusti neque talibus assotiati

Culpis gestorum, quę damnent, more reorum.

380 Ex his nullus erit, qui nos convincere possit

Sanguine de fratris nec non de morte parentis.

Celibis illesam cupientes ducere vitam

Grates factori persolvimus omnipotenti, Leges qui statuit, facti moderamina iussit.

385 Quę dare non poteras, hostili iure tenebas, Nobis iurabas, ex hoc tibi consociaras

Annis iam septem; vis nos incurrere mortem?

Non ita promeriti sic nos opponere morti.

Fraudibus in vulpis que sit tibi causa timoris,

390 Ne feriant iacula, quę presens concio vibrat,

Discere percupimus, celatum quod latet ulcus.

LVPVS.

,Tempore, quo reges vadunt ad bella feroces,

Renibus in silvis torquetur vita leonis.

394 Forte fuit causa, decatie lege recepta,

396 Exiit edictum, silve fera currat ad antrum,

Aegroti membris apportet queque salutis.

Omnes hac properant, nullum vitale ministrant, Quod prosit capiti, cruri ventrique pedique.

395 Attavus eligitur, camerarius ille notatur.

400 Est sibi commissum, peragret consorcia fratrum;

An quis deficiat, crebro meditamine pensat.

Absunt a reliquis caute medicamina vulpis.

Auribus hec regis mox infert sedulus hostis,

His peiora sonat: illum quod tradere querat.

405 Imperat egrotus, quicumque est fidus amicus, Vt vulpem capiat, membratim membra resolvat:

Attavus ut novit, cruciatus mira requirit:

Arbore de celsa vulpi crux figitur alta.

Condoluit pardus confratrum de grege solus,

410 Conprendit cursum, regis depromere iussum.

Finitis stadiis quingentis atque vicenis,

Jam prope lassescenti occurrerat obvia vulpes; 
Give a free reply and hold the wolf in check with words like these:

"Let us not be unjust nor linked with such

Wrongful deeds that might condemn us as though guilty.

380 There will be none of these who could convict us

Of having shed the blood of a brother or killed a parent.

Desiring to lead the innocent life of a celibate,

We paid thanks to the all-powerful Maker

Who established the laws and decreed the guidance of actions.

What you could not give (did not own), you held in your hostile manner, And swore an oath to us, thus binding yourself to us

For seven years; do you wish us to incur death?

In this manner we did not deserve thus to face death.

Whatever may be the cause of your fear about the treachery of the fox,

390 I mean the fear lest they cast javelins which the assembled crowd is [brandishing,

That is what we desire to learn, because the sore is hidden (in you)."

(Wolf) "At the time of year (in spring) when courageous kings go to war, The life of the lion in the woods is tortured by pains of the kidney.

394 It happened by chance at the time the law of the tithe was decreed,

396 That the edict went out that the beasts of the forest should hurry to the And bring anything sanative for the limbs of the sick king. [cave All hurry hither but bring nothing life-giving Which might benefit head, leg, stomach or foot.

395 My ancestor is chosen, he is designated chamberlain,

400 And he is ordered to go through the gathering of brethren;

He ponders with frequent meditation who may be missing.

There are absent from the rest the medicines of the clever fox.

The fox's eager foe soon bears this to the ears of the king,

And worse things than these he reports: that the fox is trying to betray the The sick king commands that whoever is a loyal friend [king.

Should seize the fox and tear him limb from limb.

When my ancestor learns it, he demands remarkable torture:

A lofty cross is hung for the fox from a high tree.

The panther alone in the gathering of brethren was sorry,

410 He went on a run to report the order of the king.

After five hundred stadia ( 60 miles) had been completed,

The fox happened to meet the panther as he was almost exhausted; 
Quę vidit, recitat, cruciatus nec quoque cęlat.

Vt nova suscepit, palmas utrasque tetendit,

415 Alfa petit simul $\omega$, tormento salvet ab illo,

Et quę vera capit, subridens irrita fingit.

Hęc pardum satiat, Trevirensia vina propinat.

Vt bene sunt pransi, benedicunt omnipotenti,

Nam modicum pausant ac iussa silentia servant;

420 Post iter arripiunt, Davitica carmina prendunt,

Se simul excutiunt, montana cacumina scandunt;

Inibi considunt, fini concepta reducunt.

Terminat has laudes defessa monastica vulpes:

,Christum de celis conlaudet spiritus omnis!

425 Mox genu curvavit, simul hec oramina fudit:

,Christe, patris fili, mihi te decet en misereri,

Sum memor ipse mei satis et mea frivola novi,

Tu mihi sis galea, qui formas muta elementa,

Me facias reducem, fallacem subrue testem.

430 Solvit vincla pedum tenditque leonis ad antrum.

Cum prope pervenit, ,miserere mei, deus‘ inquit.

VVLPES PARDO.

,Hic maneas, donec regis molimina noscas.

Quercus adest iuxta, cui figas posteriora.'

Non tamen indecorem sua se regina relinquit,

435 Namque vię comiti dodrantem contulit auri.

$\mathrm{Hec}$ pede composito sese sociaverat antro.

Pectore cum tremulo stetit antri limine primo, Intro caput flexit, domnum benedicere poscit.

Quę benedicitur, a sociis set Amen geminatur.

LEO.

440 ,Belua multorum capitum, visis moribundum?

VVLPES.

LEO.

,Ad quid venissem, si non medicamina ferrem?'

,A grege cur fratrum certas divellere gressum?

Inspice concilium, si desit quis sociarum.'

vVLPES.

,Hercle iacere tuum, per magna silentia pressum!‘

LEO.

,Discere persicio, quid te semoverit antro. 
What he saw he reports, nor does he conceal the tortures.

When the fox had learned the news, he raised up both his hands And implores the Alpha and Omega (God) to spare him that torment, And smiling he pretends that what he knows to be truth is meaningless. He gives the panther enough to eat and pledges to him with wine of After eating well they bless the Almighty, [Trèves.

And pausing a little, they observe the silence that was ordered;

Then they take quickly to the road, intone the hymns of David, Take confession at the same time and climb the top of the mountain; There they sit down and utter their prayers to the end.

The tired monastic fox ends these hymns thus:

"Let all that have breath praise Christ sent from heaven!"

Soon he bent his knee and at the same time poured forth this prayer: "Christ, Son of the Father, behold, it is proper that Thou pitiest me,

I know myself well enough and am aware of my weaknesses,

Be my helmet, Thou who givest form to the silent elements,

Make me to return home and destroy the false witness."

430 He takes off the shackles of his feet (his shoes!) and makes for the lion's When he came near he said, "Take pity upon me, Lord." [cave. (Fox to panther) "Stay here until you know the mighty disposition of the

[king.

There is an oak nearby against which you may stand with your back." None the less not without reward did his queen (the fox: vulpis, f.) leave [the panther,

For to the comrade of his way he gave three-quarters pounds (nine ounces) With measured step the fox had approached the cave. [of gold. With trembling heart he stood at the outer limits, Bent his head forward and asked the master to bless him. He is blessed, and "Amen" is spoken twice by the comrades.

440 (Lion) "Beast of many heads (hypocrite), do you come to visit one who [is dying?"

(Fox) "For what would I have come if not to bring medicine?"

(Lion) "Why do you strive to keep your step away from the gathering of [brethren?

Inspect the council, if any of our comrades is missing."

(Fox) "By Hercules, your sick-bed, oppressed by great silence (loneliness)!" (Lion) "I thirst to find out what kept you from our cave." 
VVLPES.

LEO VVLPI.

VVLPES.

VVLPES.

,Stagnum Genesaret cum fulica transvolitaret, Me visa rediit, de te mox talia pandit:

"Cara soror vulpes, quenam nova tristibus affers?

An leo convaluit, quem punctio dira gravavit?

450 Fit planctus grandis in partibus hisce marinis.

Currito, festina: latet hoc medicamine vita.

Quod tibi compono, compone fideliter egro.

$\mathrm{Vt}$ fias agilis nec erres montibus istis:

Hac iter ad levam, per quod descendito Romam,

455 Burdegalo castro cursu tendas properato;

Psitachus occurret, regis tentoria queret,

Illi mox dices, quę tunc certissima scies;

Nam regi domino supplex oramina mando."

Hec dicens rediit, pacis simul oscula pressit.

460 Finibus Italicis, fessis cum robore membris,

More peregrini mirans ripatica Padi,

Dum prope perveni pontatica fixa Ticini,

Venerat inmenso merens ciconia rostro.

Fulica quę dixit, eadem gemebunda revolvit;

465 Addidit hoc solum, sanctum deposcier Aprum.

Prosperet incepta, confirmet tot mihi iussa!"

,De te multa volant, quę vitam crimine turpant.“

,Circator veniat, dictum scelus omne revolvat:

Si dignum morti, cogar succumbere legi;

470 Iudicor innocua, domini letabor in aula."

Totus conticuit grex, atque crucis siluit lex.

,Quicquid sub terra est, in apricum proferet etas.

Singula de nobis anni predantur euntes,

Iam tempestivi funduntur vertice cani,

475 Auribus ecce meis inolevit pluma senilis,

Aspera iam pellis insedit cruribus istis;

Nocte dieque gravi franguntur crura dolore,

Non cursu superabo canem, nec viribus aprum,

Assimilor cigno, commutor corpore toto, 
(Fox) "When the coot was flying across the sea of Gennesaret, It saw me and returned and presently revealed such words about you:

'Dear sister fox, what news do you bring us in our sadness? Has the lion got well, whom dreadful pain (stabbing) oppressed?

450 In these seaside parts great mourning occurs.

Run, hurry: life is concealed in this medicine,

What I entrust to you, entrust it faithfully to the invalid.

That you may be speedy and not err about in these mountains:

From here take the road to the left and by it go down toward Rome,

And with hasty step make for the fortress of Bordeaux;

The parrot will meet you, seeking the tents of the king,

Tell him forthwith what you will then know for certain:

I commend my prayers as a suppliant to our lord, the king.'

Speaking thus, the coot left again and gave me the kiss of peace.

460 When in the confines of Italy, with limbs exhausted of strength,

I admired the banks of the Po in the manner of a foreigner,

And when I approached the permanent bridge of the Ticino,

There came the mourning stork with his huge bill.

$\mathrm{He}$, sighing, repeated what the coot had said;

This alone he added: "That ardent prayers be directed to St. Aper.

May he prosper what I have begun and strengthen my many commands!"

(Lion to fox) "Many things fly about concerning you which besmirch your

[life with crime."

(Fox) "Let the inquisitor come, let him disclose my whole guilt that has

[been mentioned:

If it is deserving of death, let me be forced to succumb to the law;

470 If I am judged innocent, I shall rejoice in the palace of my master."

The entire gathering was silent and the law of the cross hushed (crucifixion

[no longer mentioned).

(Fox) "Whatever is under the surface of the earth, time will bring it into The passing years take one thing after another from us,

[the sun.

Gray hair, premature, is already diffused over my head,

And see how the down of old age has already grown around my ears,

And how a hide, already coarse, has settled upon my legs;

By night and day my legs are racked with severe pain,

I cannot excel the dog in running, nor the boar in strength,

I am like the swan, changing all over my body, 
480 Conrugor, felix velud assolet Indica cornix:

Proque salute tui peragravi climata mundi."

Atque ita mentitur, sic veris falsa remiscet,

Primo ne medium, medio ne discrepet imum,

Promta sequi tortum potius, quam dicere verum.

485 Flebilis ista feris placuit sententia vulpis,

Conclamant omnes: ,veneretur olimpica vulpes!"

Sternuntur pedibus nec sese segregat ullus,

Proque labore gravi superest miseratio vulpi,

Principis ira perit, nam vulpis gloria crescit:

490 Carmine sollemni deducitur obvia regi.

Hęc sceptrum regis tetigit sub federe pacis,

Tempore sic pacis fuerat mos regibus illo.

LEO.

,Fulica quę misit, sollers industria vexit,

Proferto ad medium conventus silvicolarum.

VVLPES.

495 ,Nolle meum dicam, medicamina iussa requiram.

Summus preco domus, quamquam meus ille patrinus',

- Est lupus hic dictus, pastoribus usque perosus, -

,Pre foribus curtis, ne turbet viscera regis,

Sane ducatur, sed et unguibus excorietur.

500 Hoc faciat cicius geminis cum lincibus ursus.

De cerebro piscis, tuleram quod partibus Indis,

Illiniam dorsum, renes, simul ilia circum;

Renes egroti stringentur pelle recenti,

Per calidum vellus spargetur morbus acutus.'

LEO.

505 ,Nil mihi tam bellum, carum, quam vivere sanum.

Flentibus hic paucis discedit mestus amicis.

Iusserat ut vulpes, certant componere linces,

Cum quibus est ursus nativo murmure motus;

Nam caput atque pedes hi salvant excoriantes,

$510 \mathrm{Ab}$ humeris sursum denudant usque deorsum.

Vnguitur infirmus, precingitur ac refovetur.

Cum resideret humi, iussit sibi pocula ferri;

$\mathrm{Vt}$ modicum biberat, confestim talia narrat:

VVLPES.

,Heu male fida cohors, male sarto federe concors, 
480 I shrivel up, as the happy Indian crow (phoenix) is wont to do:

To find health for you I traversed the breadth of the earth."

Thus then he lies, thus he mixes falsehood with truth,

So that the middle would not be at variance with the beginning nor the [end with the middle,

Ready rather to follow the tortuous path than to speak the truth.

This weepy mood of the fox pleased the beasts,

And all shout in unison: "Let the Olympian fox be venerated!"

They kneel at his feet, and no one stands aside,

And pity remains the lot of the fox for his heavy toil.

The wrath of the ruler vanishes, and the reputation of the fox grows:

490 With a solemn hymn he is brought before the king.

He touched the scepter of the king to be assured of the pledge of peace,

This being the way to pledge peace among kings at that time.

(Lion) "What the coot has sent and your clever energy has brought,

Bring it forth in the midst of the assemblage of the denizens of the forest."

(Fox) "I will speak my reluctance, I will seek out the cure that has been

[ordered.

The highest herold of the house, although he is my uncle" -

It is the wolf that is meant, much hated by the shepherds -

"Let him be led discreetly before the gates of the Court, lest it affect

The viscera of the king, but then let him be flayed down to his toenails.

500 The bear can do this more readily with two lynxes.

With the brain of a fish which I have brought from the regions of India I shall smear his back, kidneys, and also his groin from top to bottom; The kidneys of the invalid shall be covered with the newly acquired hide, And his acute illness shall be dissipated by the warm pelt."

(Lion) "Nothing is so pleasant and dear to me as to live in good health." The wolf departs sadly with only a few of his friends weeping.

As the fox had ordered, the lynxes strive to carry things out, And with them the bear arose with his characteristic growling; As they flay they spare only his head and feet,

510 And they denude him from up on the shoulders all the way down.

The sick king is anointed, enveloped in the hide and made warm again. When the fox sat down on the ground he asked that a goblet be brought After drinking a little he straightway speaks as follows:

[him;

(Fox) "Woe, horde of bad faith, united in ill-ordered trust. 
515 Quam temere in vosmet legem sancitis iniquam!

Si volumus genti, si nobis vivere cari,

Dum licet ac vultum servat fortuna benignum,

Legis decretum servemus more parentum:

Indigni quodcumque sumus disrumpere fedus,

$520 \mathrm{Hec}$ res conservat iunctos et iungit amicos.

At vos virtutes ipsas invertitis omnes,

Non mihi iudicium, sed vobis ponitis ipsum.

Dedecet hunc regem rationem scribere talem:

,Absens damnetur', nisi legibus ante vocetur.

525 Si sequitur legem, mercabitur undique laudem;

Si refugit placitum semel ac bis terque petitus,

$\mathrm{Nec}$ premit hunc morbus tardatque vicarius huius,

Hic subit et perfert, quod quisque viriliter horret,

Nec sit lugendus, si deperit in cruce tensus.

530 Verum nil sceleris faciet pia dextera regis:

Sensibus intendat, legis precepta revolvat

Micius acclini timido, quam corde tumenti.

Nullius ore viri sensi nec discere quivi.

Tardius adveni, magis istis omnibus egi.

535 Obsecro clementem mihimet mitescere regem.

Si male quid dixi, reprobet grex istius antri;

Si quid et utilius, carum ferat iste senatus.'

Collaudant, venerantur, amant et laude frequentant.

VVLPES.

,Esurit egrotus langore fameque gravatus;

540 Languidus in cubitum iam se conviva reponat,

Vescatur dominus, monachilis quę vehit usus:

Pane, fabis, variis herbis tellure creatis,

Pomis, lacte, mero, caseis, sale, melle et olivo,

Piscibus et pavis, turdis, calidisque placentis,

545 Pinguibus et ficis, bolletis nec sine mergis;

Regali disco iungatur sturio cęto 
How rashly you sanction a judgment unfair to yourselves!

If we wish to live valued by the people and ourselves,

Let us, while we can and while fortune shows a kindly face,

Serve the statute of the law as did our parents:

We are unworthy if we break any bonds,

520 This (harmony) keeps together those who are one, and links friends.

But you turn all these virtues upside down,

Not on me do you pass judgment, but on yourselves.

It is unworthy of our king to write a decree which says

That the absent defendant should be condemned, unless summoned

[previously by law.

If he follows the law he will earn praise from all sides;

If he shuns the assembled court, though summoned once, and again, and And illness does not oppress him nor his attorney delay hin, [thrice, He will undergo and suffer what everyone greatly abhorrs,

And he should not be mourned if he dies stretched out on the cross.

530 But the holy right hand of the king should commit no crime:

Let him strive for good sense and ponder the precepts of the law

More indulgently toward the fainthearted than toward one whose spirits

[are easily excited.

From no man's mouth have I gained knowledge, nor have I been able to

[learn.

Though I came later, yet I have accomplished more than all of these. $I$ beg the lenient king to be forbearing with me.

If I have said anything evilly, may the gathering in this cave reproach me, But if I have also uttered something useful, may this senate (assemblage [of beasts) hold it dear."

They laud him, they honor him, they show him love, and they surround [him with cheers.

(Fox) "The sick king is hungry, burdened by fatigue and lack of food:

540 Let him, as a banqueter, recline and languidly lean on his elbow,

Let the master feast on what monkish custom offers:

On bread, beans, various herbs grown in the soil,

Apples, milk, pure wine, cheese, salt, honey and olives,

Fish and peacocks, thrush and warm cakes,

Plump figs, mushrooms, not to forget diving birds;

Let the sturgeon be joined on the royal table to the whale 
Qui vomuit Ionam refugam mestumque profetam;

Dulce saporatis oneretur discus herilis.

Precipiat dominus, ut serviat huic leopardus,

550 Suggerat inpensas ponto et tellure creatas,

Vel que Iudaicis fraglant bene condita capsis.

LEO VVLPI.

,Tu dispone domum, ne quis sollicitet egrum

$\mathrm{Nec}$ quisquam noceat cupido mihi pacis, et ultra

De grege conventus non sit qui calcitret ullus.

555 Qui te commorit, melius non tangere scibit, Verbere contorto toto torquebitur antro.

Colla superborum discent quę pena reorum.

Currite tranquillum, vulpis cognoscite iussum:

Qui veneratur erum, veneretur ad omne ministrum.

560 Gestamen sceptri vulpi concesserat illi.

Plus solito maior percurrit pectora terror,

Nec vox ulla valet, pompe vis nulla relucet.

Tunc tremefacta cohors complet, quod iusserat eros,

Assurgunt cuncti, submittunt colla iubenti.

565 Innuit ille, domus comes ut properet leopardus

Accelerare, palatinam quod condecet aulam:

Castos paneficos, fartores ac ciniflones,

571 Potio quo fiat vel quis cristallica promat,

568 Quis pincerna domus, dapifer, nec prodigus ullus

569 (Nullus tam parcus, quin prodigus ex alieno).

570 ,Secreti tacitus camerarius ordine denus,

572 Servator porte sit cautus limine lingue,

Lignifer a nemore comportet robora silve,

Torrida ligna vehat, ne fumi virgula surgat,

575 Quo corrumpantur dorsalia, nec vitientur

Pallia suspensa, substrata tapecia mira;

Pervigiles multi, grandis sit copia curti,

Verrere valde domum, ne quid sit quisquiliarum, 
Which belched up the fugitive Jonah, the sad prophet;

And let the master's table be filled with sweetly flavored food,

Let the master instruct the leopard to serve him,

550 And let the leopard bring what is expended by the sea and grown in the

[earth,

Or what is well preserved in Jewish capsules and smells sweetly."

(Lion to fox) "You keep the house in order, lest anyone disturb me, sick Nor let anyone harm me, desirous of peace, and what is more, [man, Let there not be anyone in the gathering who may kick up his heels.

Whoever may disturb you shall know it is better not to touch you,

He will be tortured all over the cave with the twisted flail.

The necks of the haughty shall learn what is the punishment for the guilty. Run along in peace and learn to know the commands of the fox:

Whoever venerates the master should venerate his minister (servant) in [everything."

560 He had granted the wielding of the scepter to the fox.

Greater fear, more than was wont, goes through their hearts,

No voice is able to speak, no show of pride shines forth.

Then the intimidated gathering carries out what the master had com-

[manded,

All rise and offer their necks to him who was giving orders (the fox),

He gave the sign that the leopard as majordomo should hasten

To provide with speed what befitted the palatial hall:

567 Cleanly bakers of bread, sausage makers and hair-curlers,

571 The man by whom the beverages are made or who brings out the crystal

[ware,

Who is the butier of the house, the cup-bearer - no one should be a

[squanderer

(No one is so stingy but that he does not waste other people's goods).

"Let the chamberlain, tenth in rank, treat secrets with silence,

Let the gate-keeper be careful with the threshhold of his tongue,

Let the wood-bearer carry the forest oaks from the grove,

Let him bring dry logs, so that no column of smoke rise,

Whereby wall covers are ruined and so that no harm be done

To hanging drapes and to wonderful carpets spread out;

Many should be watchful, and there should be a great throng at court, To sweep the house well, lest there be any trash, 
Rursus odoriferum renovetur floribus antrum;

580 Lumina largiflue statuantur cerea mense, Officiis dictis non desit aquarius istis

Descriptis gradibus non sit qui murmuret ullus. Illustris monachi captivi, nomine Malchi, Forcia cum vita recitentur in ordine gesta;

585 Percipiant animi dociles teneantque fideles; Vnicornis, ad hęc perstrenua, conferat istęc, Voce puellari delectet pectora cleri,

Convivas delectando pariterque monendo, Nam mixtum capiat, languens ne forte gravescat.

590 Exeat hinc dominus; orto est nam proxima quercus, Membra sub adversa ponat languentia quercu, Esuriesque sitis visis reparabitur erbis, Quas habet hęc orti species et amena venustas, Quas lambit nitidi circumflua copia fontis;

595 Nil luteum de fonte fluit, nec turbidus humor Nascitur, aut prime violatur origine vene. At nos delicias plumarum et linea texta Sternimus atque cutem fulcro tenuante polimus. Audiet et lirice modulamina celsa puelle.

600 Non decet egrotum, tanto medicamine tectum, Tam cito se sociare thoro nec iungere disco. At domus hec domini pingatur flore recenti, Cortinis croceis per longa palatia tensis.

Cetera formentur, velut usus regis habetur.

605 Namque manus vulpis sustentat membra leonis Ac latus egroti, ducens per lilia prati;

$\mathrm{Nec}$ pes ire valet, nec cervix prevalet illi. ,Turbe condoleo, triduo iam sustinet antro,

Esurit atque sitit, ieiuno corde fatiscit;

610 Pro morbo regis conventus condolet omnis, Nil falsi simulat, sed amica pace salutat, 
And flowers should be brought into the cave so that it may smell sweet 580 Candles of wax shall be set upon the copious table, [again; And in addition to the offices mentioned, a water-bearer shall not be [lacking,

Nor let anyone grumble now that these steps have been described.

Let the brave deeds of the famed captive monk, Malchus by name, be recited in orderly fashion together with his life;

Let the minds that would learn perceive it, and the faithful remember it; Let the unicorn, energetic in this, bring these things together.

Let her delight the hearts of the clergy (the beasts) with her maidenly [voice,

Delighting the table companions and at the same time admonishing them, And let her take a mixture (of food), lest weak as she is, she may grow

[worse.

590 Let the lord go away from here; near the garden there is an oak, Let him settle his tired limbs under this oak facing him, And hunger and thirst will return, when he sees the herbs Which this kind of garden with its pleasant beauty offers, Which the encircling abundance of the sparkling fountain laps; Nothing flows muddy from the fountain, nor is any cloudy water Produced, nor is it disturbed in the home of its primal source.

But we will spread the luxury of feathers and woven Linens, and smooth his skin on a relaxing bed.

Let him hear also the noble singing of the lyric maiden (the unicorn).

600 It is not meet for a sick man, covered with such a means of healing, To go to the couch so soon or to share in the food of the table.

Let this home of the master be adorned with fresh flowers, With saffron-colored arches spanned throughout the spacious palace. Let other matters be arranged as the custom of the king dictates." Now the hand of the fox supports the limbs of the lion And the flank of the sick king, leading him through the lilies of the field; For the foot of the invalid cannot walk, nor is his neck very strong; (Leopard to fox) "I am sorry for the retinue, for three days now they are [holding out in the cave, They are hungry and thirsty, they are exhausted, with famished stomach;

610 The whole gathering mourns over the sickness of their king, They feign nothing false but salute you in friendly peacefulness, 
Tu quocumque iubes, una sunt voce sequentes;

Diversisque modis tua curabuntur $a b$ istis;

Ecce casis clausis consedit turba fidelis.

615 Ergo fave votis, qui servas intima regis:

Tu quamcumque deus tibi fortunaverit horam, Vt cuique est etas, ita quemque facetus adopta, Quo sit amore parens, quo frater amandus et hospes, Rusticus urbano quid distet, turpis honesto.'

VVLPES.

620 ,Consilium melius proavorum non dedit ullus, Nec potiore cibo pavit quis tempore tanto.

Si potis est fieri, titubet ne gratia domni, Dum domus excolitur, generaliter esca paretur;

Qui servire valet, acri ne dente retardet,

625 Ille cibum capiat, domino qui sponte ministrat."

LEOPARDVS.

,Vncta satis spisso ponentur oluscula lardo,

Nec satis est, cara pisces avertere mensa;

Semesos pisces, quos Indus liquerat hospes,

Insimul accipiant, equato munere carpant.

630 Que sint cumque dapes, siciunt consumere fauces, Ieiunus raro stomachus vulgaria temnit."

VVLPES.

,Causa namque tui rorentur munere Bachi;

Vt bene sunt pransi, redeant ad limina templi.‘

Confestim tristes leopardus currit ad ędes

635 Exclamatque palam, conventus deserat aulam:

,Currite vos cicius, sic rex iubet iste secundus:

Ilice sub densa stomachantia sternite membra, Horas cantate, jentacula parta vorate, Deque cibo celeres proprias cognoscite sedes.

640 Non strepitus vocis nec sit mutatio sedis.

Ligna ferant ursi, comportent suta cameli, Nam latices luter, deducat aquatica fiber.

Sic fiat, sic sit; horum natura reposcit.

Obsequio tigridis curetur copia panis, 
And whenever you order them, they follow with one voice;

In various ways your interests are cared for by them;

Lo, your faithful throng has settled in closed quarters.

Therefore look upon their prayers with favor, you who serve the personal [needs of the king:

Whatever hour a god has chosen as propitious for you,

Depending on each one's age, accept him gracefully

With whatever love a parent, a brother, a guest is to be loved,

But let the rustic be somewhat distinguished from the city man, and the

[mean from the honorable."

620 (Fox) "None of our ancestors has given better counsel,

Nor has anyone trembled for (craved) better food at such a time.

If it can be arranged that the good will of the lord will not waver,

Let the food be prepared by all while the house is being bedecked;

Whoever is able to serve, let him not hold back with a sharp tooth,

Let him take food whoever willingly serves the master."

(Leopard) "Let cabbage sufficiently greased with rich bacon be served,

Nor is it enough to take away fish from an expensive stand;

Half eaten fish which the guest from India had left us,

These the beasts shall also receive and seize in equal shares.

630 Whatever feasts take place, jaws are eager to eat them,

And the hungry gullet rarely refuses every-day food."

(Fox) "Now because you wish it so, let them be moistened with the gift of

[Bacchus;

After feasting well, let them return to the threshold of the temple."

Straightway the leopard runs to the house of gloom

And exclaims publicly that the gathering should leave the court:

(Leopard) "Run quickly, thus your second king (the fox; or leopard?)

[commands you:

Under the spreading oak rest your vexed limbs,

Intone the hours and devour the breakfast prepared for you,

And after the meal find your own places (duties) quickly.

640 Let there be no buzz of voices nor change of places.

Let the bears bring wood, the camels coverings,

And let the otter bring spring water, the beaver river water.

So let it be done, so let it be; their nature demands it.

Let the supply of bread be a care for the kindness of the tiger, 
645 Piscibus aptandis, avibus raris piperandis, Escis cum reliquis nigris sollercia barris.

Preponor dapibus, disponat pocula cervus, Dente timendus aper, turbatis viribus acer, Has portas servet, nobis obstancia spectet.

APER.

650 ,Ne venatores suffocent nos velut hostes:

Fagus adest alta, conscendat squirio celsa, Hos peragret visu, percurram cetera sensu.

LEOPARDVS.

,Linces cum dammis, hi sint custodia regis, Cerula catta maris conservet strata iacentis.

655 Tincta super lectos candescat vestis eburnos, Simia deformis reparet candelabra lichnis; Impiger ericius, condenso vellere tectus, Poma vehat, miranda canat, sed amigdala ponat, Atque nuces corili sint mense largiter isti.“

ERICIVS.

660 ,Squirio quam nobis compilat pomula glandis! Quis tibi vel qualis? magni sum gente Catonis;

Ex atavis longo si ducis stemmata filo, Disces me natum magnorum sanguine regum, In me priscorum virtus defluxit avorum.

665 Stirpe recenseta removebis vilia iussa, Iuxta progeniem manda serviminis artem.

LEOPARDVS. ERICIVS.

LEOPARDVS. ERICIVS.

,Convenit ecce tibi talis reverentia fati. ,Hinc vivam reliquo despectior ipse popello.

,Tempore namque suo generis recitabitur ordo. 670 ,Non sequar hoc iussum, deposcens te leopardum, Precipias numquam mihi contemptibile quicquam. Si brevis existo, prudenti regmine regno; Ingenium purum, sapiens, subtile, serenum. Vilibus involucris latitat substantia grandis:

675 Marchio sum Rutulis, Romane signifer urbis. Est testudo mihi spatiosa, cacumine saxi 
To preparing fish and spicings rare birds,

Together with other foods, the attention of the black elephants shall be

[turned.

I shall preside over the feast, let the stag pass out the goblets,

While the boar, feared for his tooth and keen when his strength is aroused,

Shall guard these gates and watch out for opposition to us."

650 (Boar) "Lest the hunters throttle us like foes:

There is a lofty beech-tree nearby, let the squirrel ascend the height,

Let him keep his eye upon them, while I will do the rest with my power

[of scent."

(Leopard) "The lynxes with the deer, they shall be the king's guard, And the dark-blue long-tailed monkey shall care for the bed of the invalid.

A dyed cover shall be resplendent on the ivory bedstead,

While the ugly ape shall put new candles into the candelabra;

The active hedgehog, covered with a thick fleece,

Shall bring apples, sing of miraculous deeds, and offer almonds,

And may there be hazelnuts in generous numbers for the table."

660 (Hedgehog) "How the squirrel gathers acorns for us!

Who am I to you, and of what quality? I am of the race of great Cato;

If you trace my lineage in a long line from my ancestors,

You will learn that I am of the blood of great kings,

To me the excellency of ancient forebears has come down.

Considering my ancestry you will revoke such disgraceful commands,

Enjoin the practice of menial service in accordance with the state of one's

[birth."

(Leopard) "Indeed, it is fitting that you respect such a lot."

(Hedgehog) "Because of this I must live (be regarded) more contemptible

[to (by) the rest of the populace."

(Leopard) "The rank of your lineage will be proclaimed in due time."

670 (Hedgehog) "I will not obey that order, and beseech you, leopard,

Never to give me any disgraceful command.

Even though small, I rule with prudent sway;

Clear, wise, subtle and calm is my spirit.

Beneath my humble exterior momentous substance is concealed:

I am a Rutulian margrave, the banner-bearer of the Roman city.

I have a spacious castle, with its rocky summit 
Tucior illa magis quam sit munimine regis:

Vnius in funda pelluntur milia dena,

Prevalet argutas hostis vitare sagittas;

680 Scandenti pediti non est via libera soli,

Vix culix quisquam volitans conscendet eandem,

Sic clivus castri teretis quasi sperula pomi;

Alpibus Italicis his mons est altior illis;

Millenis cubitis preruptior atque vicenis,

685 Oppida Chuonradi coguntur ad hunc famulari.

Manna vescuntur, qui nostra curte fruuntur.

Est hoc speleum Teutonice Stensile dictum,

Anguis est dictus vere portarius huius,

Et cameram lecti scias Hunsaloa vocari.

690 Vltra serviciis si me non truseris ullis,

Ista tue soboli tradam sub clave sigilli;

Caucio firmatur, conventio si stabilitur.

Tritas servitio manicas non exigo longo.

LEOPARDVS.

,Scandero si solium, spernam te valde superbum.

695 I puer atque mee citus hunc impone coquine;

Dum tostat verua, scutelle balnea potet.

Potus hic est habilis simili sub more superbis.'

ERICIVS.

LEOPARDVS.

,Quo deus et quo dura vocat fortuna, sequamur.

,Dedecus est dominis, dum laxant debita servis.

700 Argumentum ingens testis sentencia prodit.

Jus est hoc modicis, semet preponere celsis,

Corpore qui parvo peragunt contraria magno:

Quamquam forma minor, verum prudentia maior,

Viribus imbelles, astu tamen acre rebelles,

705 Artibus expugnant, cum robore membra fatiscant.

VVLPES.

,Talia conferre compellit simius iste.

Consule, care, tuis, nam dictis te volo paucis."

LEPARDVS.

,Fac spatium socio, tibi mox parere parabo.

VVLPES.

,Vult dominus secum fratren de pluribus unum,

710 Qui recitet spalmos, divinos personet ymnos,

Organa spalterii repetat modulamine dulci.

Impedior lacrimis prorumpere nomen amantis: 
Much more secure than it would be under the king's protection:

Ten thousand are driven away by the sling of one defender,

And it can withstand the sharp arrows of the enemy;

680 There is no path open for a single foot-soldier to climb up,

Scarcely could a gnat ascend it in flight,

The hill of the fortress is like the sphere of a smooth apple;

The eminence is higher than those Italian Alps;

It drops more than a thousand and twenty cubits,

The towns of Conrad are compelled to serve it.

They feed on manna who enjoy our court.

This cave is called in German Stensile

And its gate-keeper is fittingly called the snake,

And the bedroom you should know is called Hunsaloa.

690 If from now on you would not push me into servility,

I shall hand this over to your descendants under the key of the seal;

A guarantee is established once the agreement is made.

I do not want to wear my sleeves out in long servitude."

(Leopard) "If I should ascend the throne, I shall despise you who are

Go, boy, and run fast and take him to the cook ;

[truly haughty.

While he roasts spits, let him drink dish water.

Such a drink is right under a similar custom (condition) for haughty folk." (Hedgehog) "Let us follow where God and a cruel fortune call us."

(Leopard) "It is a disgrace for the masters when they relax their ob-

700 What the witness says offers strong proof. [ligation to their servants.

It is the custom among inferior people to rank themselves ahead of those

[of high station,

Who with a small body carry out acts opposed to the great:

Although their build is smaller, their sagacity is greater, Impotent in strength, yet insurgent in keen stratagem,

They are victorious in cunning when their limbs tire in strength."

(Fox) "This ape forces one to reach such conclusions.

Pay heed to your duties, my dear; I wish your attention for a few words."

(Leopard) "Give time to a friend, soon I shall be prepared to obey you."

(Fox) "The master wishes a brother with him, one of us many,

710 Who will recite psalms and sing holy hymns

And repeat the melody of the psalter with sweet harmony"

I am prevented by tears from blurting forth the name of the beloved: 
Virtutes pardum comitantur amiciter istum.

Non est periurus neque sordidus ac furiosus,

715 Comis et urbanus, animo pius, ore serenus,

Consilio cautus, moderatus, pacis amicus,

Novit, quid pulcrum, quid turpe, quid utile, falsum;

Si foret ad presens, solus precelleret omnes.

LEOPARDVS.

,Fiat velle tuum, simplex dumtaxat et unum,

720 Sit fixum, quod vis; sit vivax gratia nobis.

Dum lupus infestus pecori, venantibus apri,

Frigida dum pugnant calidis, humentia siccis,

Dum nova crescendo reparabit cornua Phębe,

Sit nobis solidum concordi federe pactum.

725 Sic ait, et mediis interserit oscula labris.

VVLPES.

,Quantus amor celi, tanta est dilectio nostri."

LEOPARDVS.

VVLPES LEONI. ,Inspice, si bene sit, quod regia curia poscit.“

Egregie factum laudat vulpecula totum.

LEO.

730 ,Ad mensam vado, perforcia vina requiro.

Quinquennis vini sitis est citra mare nati.

VVLPES.

,Non valet id fieri; queras, quod possit haberi.

Ad te cum redii, Trevirensia vina probavi,

Ex his sextarium sanxi tibi ferre bibendum.

735 Dulcius ac melius nec habet scrutarier ullus,

Quod curas abigit, quod lingue verba ministrat,

Morbos avertit, metuenda pericula pellit.

Trevirici calices quos non fecere loquaces!

Inditiis certis portavi dona salutis.

LEO VVLPI. $\quad 740$,Tradere si cuperes, non tanta pericula ferres,

Debitor en meriti pro tanti pondere facti.

Crimina lingua lupi concusserat ore bilingui,

Hic crucis exicium properabat figere dirum.

Furcifer ecce iacet; non sit, qui tollere curet.

745 Hanc meruit penam, vitasti denique culpam.

vVLPES.

LEO.

,Audit, quod non vult, qui pergit dicere, quod vult."

,Demiror pardum nostrum rarescere visum. 
Good traits accompany this panther like friends.

$\mathrm{He}$ is not mendacious nor mean and quick-tenipered,

$\mathrm{He}$ is friendly and cultured, devout in spirit, and calm in speech,

Wisely deliberate in advice, moderate, and a friend of peace,

He knows what is noble, what is ugly, what is useful, and what false;

If he were present, he by himself would excel all others."

(Leopard) "Let your will be done although it is simple and your only one,

720 Let your wish be firm, and let your good will toward us be lively.

As long as the wolf is hostile to cattle, and boars to hunters,

As long as cold contends with heat and moisture with dryness,

As long as Phoebe when waxing makes the end of the crescent grow,

Let us have a firm pact with an alliance of friendship."

Thus he speaks and plants kisses in the middle of his lips.

(Fox) "As great as is the love of Heaven, so great is our friendship."

(Leopard) "See if the needs of the royal court are well met."

The little fox praises everything as well done.

(Fox to lion) "It is the hour of rising, your realm is like that of Croesus."

730 (Lion) "I shall go to the table and ask for very strong wines.

I have a thirst for five-year-old wine grown this side of the sea."

(Fox) "That cannot be done; ask for what is possible.

When I returned to you I prescribed wine from Trèves,

Of this I permitted a pint to be taken to you for drinking.

No one can find better and sweeter wine,

Which drives away cares, which serves words to the tongue,

Turns away illnesses and banishes dangers that are feared.

Whom have goblets of Trèves not made talkative!

I have brought sanative gifts of unerring characteristics (potency)."

740 (Lion to fox) "If you were eager to betray, you would not risk such danger, See, I owe you a reward for the weighty service you have performed.

The tongue of the wolf had set calumny in motion with duplicity.

He was hurriedly preparing a terrible death on the cross for you.

See, the rogue lies there; let no one take care to pick him up.

$\mathrm{He}$ has deserved this punishment, you in the end, have avoided wrong[doing."

(Fox) "Who proceeds to say what he wishes may hear things he does not

[like."

(Lion) "I am surprised that the panther makes himself so rare to our sight." 
VVLPES.

LEOPARDVS.

VVLPIS.

LEO

VVLPIS PARDO.

PARDVS VVLPI.

VVLPIS PARDO.

PARDVS.
,Ne turbere, pater: veniet mox advena frater,

Cuius ad ingressum pelletur quodque nocivum.

750 ,Quod mora sit fratris, stillis perfundor acerbis;

Si forsan periit, melior se nemo remansit:

Dispar comparibus, verax, psalmista probatus,

Sobrius, armipotens, castus, moderamine pollens,

Caucior est homine, prudentior hic Salomone.

755 ,Si redeat, visam. Decet en te poscere mensam.

Vulpes ire parat, caudam versuta regirat,

$\mathrm{Vt}$ prosit pardo, signum facit hec leopardo

Congreditur quercum, cui sciverat adfore pardum.

,Quem scio pervigilem〈semper〉 proferre laborem.

760 Quid prosit, querit, quid delectabile, poscit.'

,Non missura cutem, nisi plena cruoris, irodo!

Iuxta velle tuum velle est extollere pardum.

Escas non capiam, donec capit ille coronam.

,Ne mora sis regi, saltu transcurre celebri:

765 Regi, prefectus regno, scribere secundus.

,Mentio sit primo, si vinceris hoste superbo.

,Decidit in laqueum, quem fraude tetenderat, ipsum;

Sic David cecinit, perraro hec alea fallit."

,Iam prope psalterium finivi carmine sacrum,

770 Incumbens veniis, ne forsan victimareris.

Psalmos explebo, cecini quos usque Memento;

Psalmo finito curvabar poplite fixo."

Concurrunt ambo psalmos pariter recitando,

Deque tribus pueris dum laus finitur ab illis,

775 Se sociant regi, benedicunt suscipienti.

O qui complexus et gaudia quanta fuerunt!

Hic benedicendus, communi sorte beandus

Ducitur impransi susceptus laude magistri;

Dum manet in mediis medius permixtus amicis,

780 Vnguitur in regem, confratrum post quoque laudem.

Inspiciens regnis, viguit domus aulica regis. 
(Fox) "Do not be disturbed, father: the foreign brother will soon come, And at his entrance everything harmful will vanish."

750 (Leopard) "I am steeped in bitter tears over the brother's delay; If perchance he has perished, no one better than he has remained: Unlike his comrades, truthful, an experienced singer of psalms, Sober, powerful with arms, chaste, excellent in moderation, $\mathrm{He}$ is more clever than human kind and wiser than Solomon." (Fox) "I shall watch out whether he returns. See, then you may ask for [your meal."

The fox prepares to go, the shrewd fellow wags his tail, Thus giving a sign to the leopard to help the panther. He goes to the oak tree, where he was sure the panther would be, "Who, I know would always endure such restless toil.

760 He asks only what may be helpful, he wants to know what is amusing." (Lion) "A leech that will not leave the skin until it has sucked its fill of Like your wish, it is also mine to extol the panther. [blood. I will not take food until he receives the crown."

(Fox to panther) "Do not be a cause of delay to the king, run with your [famous bound:

You are recorded as second to the king, the prefect for the realm."

(Panther to fox) "First let there be mention if you will be vanquished by [the haughty foe."

(Fox to panther) "He fell into the very snare which he had set slyly; Thus David sang, rarely does this chance fail."

(Panther) "Already I had almost finished singing the sacred psalter,

770 Kneeling for mercy, lest perchance you be made a victim.

I will finish the psalms, I have sung them as far as Memento;

When the singing was done, I bowed but did not kneel."

Both singing the psalms together, they go,

And when the praise of the three lads is finished by them, They meet the king and bless him who receives them.

$O$ what embraces and what rejoicing there was!

$\mathrm{He}$, to be called happy and blessed according to common (human) lot, Is escorted and received by the praises of the master who has not yet While he remains in the very middle among his friends, [eaten;

$780 \mathrm{He}$ is anointed as king after hearing the praises of his brothers. Watching the royal doings, the palace of the kind was happy. 
Tunc se proluerat, mensas ex ordine donat, Imperitat geminare cibos, ut regius est mos; Nam vadit sessum, pre mensa pronit amicum.

$785 \mathrm{Ab}$ specule primis defertur sella curulis, Vulpes subrisit, dum sculpta scabella locavit. Fecit adoptivum vulpina astucia pardum! Presulis officio vulpis grex conticet omnis: Non murmur resonat, pacis concordia constat.

790 Finiit unicornis ubi memorabile Malchi, Vulpes consurgit, cristallica vascula promit, Non solum vulpes, sed multo nobiliores: Pocio talis adest, quę versu dicere non est, Quam portant regi, psallentes more precandi:

795 ,Quo sine nemo potest, qui mire condita profert,

Qui faciem celi depingit sidere pluri, Huncce egrum decoret, regem de corpore salvet. Sic sua perpetuus non claudat lumina somnus, Sed sua perpetuo vegetentur membra vigore, 800 Et peragat placitam per multa decennia vitam, Nec sibi sit medicis opus umquam, nec sibi casus Aut morbus ullum pariant quandoque laborem, Sed procul a curis et sano corpore vivat.

Nil prave cupiat, faciat, nec proferat umquam,

805 Sit vita locuples et Christi munere dives!"

Vt fluit occeanus, fluxit potus piperatus.

Singula quid memorem, superent cum singula laudem?

Nemo potest scriptis cenam depingere regis.

Inter prandendum leo scrutatur nova pardum:

810 ,Cur te subtraheres paribus, volo tu mihi narres;

Tardasti multum; velle est cognoscere certum.

PARDVS. ,Somnus te fugitat, vigilantia te cruciabat;

Condolui tibi; non parcens mihi, congrua vexi: Nec regina Saba Salomoni sic tulit alta,

815 Nec rex ille pares avium possedit honores.

Preses eas clamet, blando palpamine tractet; 
Then (after) he had washed his hands, he assigns the tables in order. He directs that the food be doubled, as is the royal custom;

Now he goes to sit down and places his friend at the head of the table. By the foremost guards the royal throne is brought, And the fox smiled while he set the carved stools in place.

The shrewdness of the fox had made the panther the royal heir!

The whole gathering was silent before the office of the fox, the leader: Not a murmur resounds, and the concord of peace exists.

790 When the unicorn had finished the noteworthy deeds of Malchus, The fox arises, takes up his crystal cup,

And not only he, but also much more noble ones:

Such a drink it is that cannot be described in verse, This they bring to the king, singing songs in a prayerful manner:

(Prayer) "Without whom no one can exist, who miraculously brings forth [what is concealed,

Who paints the face of the heavens with many stars, May He honor this invalid and save the king in body. Thus may perpetual sleep not close the king's eyes, And may his limbs thrive with constant vigor,

800 And may he spend a peaceful life for many tens of years, May he never have need of physicians, and may accident Or sickness never cause him any trouble, And may he live in a sound body far from care.

Let him never desire anything improper, nor do it, nor utter it, Let his life be rich, and precious in the favor of Christ!" As the ocean flows, so the spiced drink flowed.

Why should I mention details when the details surpass my praise?

No one can depict in writing the feast of the king.

While dining the lion questions the panther for news:

810 "Why do you withhold yourself from your comrades, I wish you would

[tell me;

You have delayed a long time; I want to have a definite answer."

(Panther) "Sleep flees you, sleeplessness tortured you;

I was sorry for you; not sparing myself, I brought appropriate help:

Neither did even the queen of Sheba bring such noble gifts to Solomon, Nor did the king himself own birds that honored him so.

Let our leader (the fox) call the birds and give them loving strokes; 
Accedat merula colludens cum filomena,

Organa quę merula miscet, luscinia mulcet.

Qui surgens currit, iuvenilia iussa peregit.

820 His capit ingressus concinno carmine primus:

,Qui rex est avium, languentem visitet istum,

Det vitam, det opes, somnos pastusque salubres,

Erigat egrotum, corroboret antra ferarum,

Prosperet hunc pardum, qui tantum deflet amicum!

LEO

FILOMENE.

FILOMENA.

825 Vobis ecce canam castam puramque Mariam, Atque Gabrihelem, qui nuntiat Hemmanuelem Virgine nascendum, mortali carne tegendum, Vt salvet populum peccati pondere pressum."

,Gusta tu modicum, possis producere cantum.

830 ,Si quid inexpertum, nobis servetur ad imum;

Nunc tamen amoto queramus seria ludo, Sit cibus ac potus Christus, qui dicitur unctus, Adsit in ore meo, dulci ferat organa plectro!‘ Hęc volitans poscit, pardum notum sibi visit, 835 Constitit a dextris, repetens insignia laudis A natalicio, quo concipit innuba virgo, Vsque sacrum flamen quo certum est adfore missum. Concentu parili memoratur passio Christi. Passer uterque deum cesum flet verbere Iesum,

840 Exanimis factus, claudens spiramina flatus;

Commutat vocem, dum turbant tristia laudem, Organa divertit, dum Christi vulnera plangit, Solvitur in luctum recolens dominum crucifixum, Squalet se cinere, dum fertur mocio terre;

845 Offuscat visum, memorans solem tenebratum. Hii gemini trepidas pressere ad pectora palmas, Vnicus ut matre, sic deflent hii pacientem. His avibus motis stupuit milicia regis, Turbatur pardus tam gratum perdere munus. ,Nec tibi nec istis sit controversia mentis! 
Let the blackbird approach, making music together with filomena (the [nightingale), And may the nightingale mollify (intone in a higher pitch) the melody the He rises and runs and carried out the orders of the youth.

820 The leader now commences for them with an artful song: "Let him who is king of the birds visit that languishing one, Let him give him life, wealth, sleep and healthful food, Raise up the sick man and make the lair of the beasts strong, May he prosper this panther who mourns such a friend! For you - hear me! - I will sing of chaste and pure Mary, And of Gabriel who announces Emanuel

Born of a virgin and to be covered with mortal flesh, That he may save his people oppressed by the weight of sin." (Lion to Filomena) "Eat a little so that you may be able to utter your [song."

830 (Filomena) "If it is something untried, let it be saved for us til the last; Yet now let us seek something serious and set levity aside,

Let Christ be my food and drink - He who is called the Anointed Shall be present in my mouth and let me pluck the song on a sweet lyre!" This she prays in flight, goes to see the panther, whom she knows, And settles at his right side, repeating the marks of His praise From His birth when the unwed virgin conceived Him, Even to the sacred wind whereby His coming was assured. In unison the passion of Christ is sung. Both birds mourn the Lord Jesus flogged with the lash, 840 They are near to death, stopping the flow of their breath; They modify their voices as sadness disturbs their song of praise, They digress from the song as they sing of the wounds of Christ, And recounting the crucifixion of the Lord, they are dissolved in grief. They soil themselves with ashes when the trembling of the earth is told; It blinds their vision (with tears) when they allude to the darkened earth. These two pressed trembling hands to their hearts.

As an only child is mourned by its mother, so they weep over the Sufferer. The followers of the king were stunned by the emotion of these birds, And the panther was disturbed to lose so welcome a boon.

850 (Panther) "Neither should you nor they be so disturbed in mind!" 
PHILOMENA.

PARDVS.

PHILOMENA.

PARDVS.

PHILOMENA.

PARDVS.

PHILOMELA.
,Linquere non potui, flevi improperia Christi.

[Singula non memoras, quẹ me dixisse stupebas?‘

,Audieram; sed fama fuit penitusque recessit.`

,Non tibi, care pater, debet istud fama videri,

855 Sed magis in cordis secreto iure recondi, $\mathrm{Vt}$ domini noscas quę sit de corde voluntas.

Ecclesie doctor quid dixerit an meministi?

,Nescio, si legi: profer, quę dixerit ipse.

,Corpus, quod mortis vitio corrumpitur, inquit,

860 Vitalem flatum, ne possit cernere verum,

Aggravat et cecis immergit sepe tenebris.

Istius exilii fleres si forte tenebras,

In quo pro primi lacrimando crimine plasti

Degemus, mecum sentires dummodo, mundum

865 Expleri cuperes eternaque desiderares,

Vt felix patriam Christo ductore redires.

Sed male, quod doleo, cęlestibus obice diro

Opponis temet nec perdita gaudia defles."

,Miror, quam patriam tu mandas esse petendam.

870 Numquid non patria est, maternis ventribus in quam

Fusi presentis fruimur servimine lucis

Affectu dulci carorum necne fovemur?

,Non equidem patria est, sed carcer mortis obumbrans;

Si patriam dicis, patriam tum credito mortis,

875 Nam vite patriam non est fas dicere talem.

Hic morbis premimur, illic sed gaudia dantur.

Quam miser atque miser, cui talia regna negari

Contigerit baratri vel sevo carcere trudi!

Vnusquisque gemat, capitalia crimina tergat,

880 Confluat ad lacrimas, si vult seducere penas!‘ 
(Philomena) "I could not refrain, I wept over the indignities suffered by

[Christ.

[Do you not mention the individual things which you were surprised

[I said?"

(Panther) "I had heard them; but it was rumor and faded completely in

[my mind."

(Philomena) "Not to you, dear father, should that seem runor,

But rather to be hidden, as is proper, in the secret recesses of the heart, That you may know what is the heart's desire of the master.

Do you recall what the teacher of the Church (Solomon) said?"

(Panther) "I do not know if I have read it: tell me what he said."

(Philomena) "The body, which is contaminated by the frailty of death, he

860 Burdens the breath of life, so that man cannot see

[said,

The truth, and often immerges in blind darkness.

If perchance you should grieve over the darkness of our exile,

In which we live because of the lamentable sin

Of the first created man, you would, provided you agree with me, desire

That the temporal world come to an end, and wish for eternal things,

So that you might return happily to your fatherland under Christ's

[guidance.

But evilly, to my regret, with a calamitous barrier, you oppose

Yourself to the heavenly host and do not lament the pleasures you have

[lost."

(Panther) "I wonder that fatherland you say should be sought.

870 Is not that our fatherland into which we, delivered

From our mother's womb, enjoy the ministration of this light

And are favored with the sweet affection of those dear to us?"

(Philomena) "It is indeed not our fatherland, but the dark dungeon of

[death,

If you call it fatherland, then believe it to be the fatherland of death, For it is sinful to call such the fatherland of life.

Here we are oppressed by diseases, but there pleasures are offered.

How wretched and doubly wretched he whose fate it is that such a

[kingdom

Is denied him and that he is pushed into the dire dungeon of the pit (hell)!

Let everyone sigh, wash away his capital sins,

880 Dissolve in tears if he wishes to set aside punishment!" 
PARDVS.

PHILOMENA

,Te peto, quo plane repetas, quę mesta canebas."

,Quantus in orbe furor, vobis modo testibus utor, Dum rapit hunc Iudea manus, (bene conscia, cuius)

Cum sic astrictis incumbunt vincla lacertis,

885 Quod iubilum cordis, patitur dum conditor orbis,

Gaudia quę plebis, legitur cum passio regis!

(Mos fuit inde prius antiquis patribus ortus,

In cruce quod Christi reticescunt signa metalli,

Non vox ulla tube resonat, sed nec quoque corde

890 Lugubre portendunt, dum mesta silentia prendunt.

Ne laus horarum consuetum transeat usum,

Fagina signa sonant, quo clerus debita solvat,

$\mathrm{Nec}$ vacat a tipicis subpressa melodia vocis.)

Turbis belligeris, ubi funditur unda cruoris,

895 Omnis risus abest, cordis violentia prodest:

Affectu cordis crescit mensura doloris.

Quis siccis referet oculis obprobria mortis,

Quod capitur dominus veluti mitissimus agnus,

Presidis ad sedem vitulus ceu ductus ad aram?

900 Ceditur et alapis, colafis quod conditor orbis?

Afficitur flagris, constringitur undique loris,

Spinea cui fertur regis pro iure corona,

Tunditur, expuitur, deluditur atque negatur,

Pocula felliti vini mox dant sicienti,

905 Clavis confixo, perfosso cuspide Christo.]

Hęc sunt, quę nostram perturbant undique mentem,‘

PARDVS.

,Plurima sat passi tractasti vulnera Christi;

Desine, cara, precor, iam desine fundere fletus, Nobiscum gaude, depellens tristia plaude.'

PHILOMENA. $\quad 910$,Nunc precor, ut dicas, cur me gaudere rogabas.

Vnde etenim tristi persuades parcere menti?

Sunt mihi leta quidem, sed tanto pondere mentem

Infero lugentem, quod me nec vivere vellem,

Sepius exopto gelido me tradere lęto.

PARDVS.

915 ,Verum (si possem) quod dicis, credere vellem, 
(Panther) "I ask you clearly to repeat the sad things of which you sang." (Philomena) "I use you only as witnesses how much sadness there is on When the Jewish hand seizes Him, well knowing who He is, [earth, When the chains press upon His arms, so bound, What joy of heart when the Creator of the world suffers, What jubilation of the people when the passion of the King is read! (It was the custom begun long ago among our ancient fathers That in the cross - crucifixion - of Christ the signals of metal be silent, That no voice of a trumpet should resound, and that not even sad

Chords should announce when the sorrowful silence is begun.

Lest the praise of the Hours violate accustomed usage,

Signals from beech-wood resound, whereby the clergy may pay its debt, And the subdued melody of the voice shall not be without figurative [meaning.)

Among the warlike multitude, when the wave of blood pours forth, All laughter is absent, and the violence of the heart is beneficial:

The measure of grief grows as the heart is stirred by affection.

Who could relate the contumely of death with dry eyes,

When the Lord is seized like the gentlest lamb,

Or led like a calf to the altar at the seat of the chieftain?

900 That the Creator of the world is subjected to cuffs and blows?

$\mathrm{He}$ is beaten with scourges, bound on both sides with thongs;

A crown of thorns is given to Him as the prerogative of a king,

$\mathrm{He}$ is beaten, spat on, mocked and rejected,

Goblets of wine mixed with gall are handed to the parched

Christ, transfixed with spikes, pierced with a spear.]

These are the things that disturb our mind at every turn."

(Panther) "You have treated the many wounds of the suffering Christ

[enough now;

Stop, my dear, I pray, now stop pouring forth your laments,

Rejoice with us, banishing sadness with jubilation."

910 (Philomena) "Now I beg you to tell me why you asked me to rejoice.

Why, I wonder, do you persuade me to spare my sad mind?

To be sure, I have joys, but I bear such a heavy weight

Of sadness that I would not wish to live,

Often I yearn to give myself over to cold death."

(Panther) "If only I could, I would want to believe that what you say is true, 
Sed pectus lubricum quoniam geris, improbo fictum.

Profer, veracem quem possim credere, testem.

PHiLomena. $\quad$ Vt quid plus referam vel secula longa retexam?

Non tibi leta manent, quod primus ab ethere plastus

PARDVS

PHILOMENAE.

PSYTACVS.

CIGNVS.

〈PSITACVS. 〉

PHILOMENA.
920 Pulsus celicolis iterum coniungitur almis?

Quę magis a nobis tractari gaudia poscis,

Quam paradisiace panduntur limina porte?

,Sufficiat tantas iamiam terebrare latebras.

Desere dedalei, iam desere limina tecti.

925 Hi lacrimis humidi, terre de pulvere fedi,

Cum iussu pardi vadunt simul amne lavari.

Cantores socii, Girinda flumine loti,

Dum repedant, reges binos dum visere certant,

Vdi, ieiuni, dicto de carmine fessi,

930 Voto communi conscendunt robora fagi.

Dum pennas aptant, plumas ex sole reformant,

Psytacus accurrit, regem resipiscere querit;

Cignus adest etiam, languentis discere vitam.

Scrutanti multa respondet avicula tanta:

935 ,Pasca resurgentis celebrandum est ędibus altis,

Quis bini reges resident, cum milite prandent;

Vos rogo, nobiscum solvatis gaudia vocum"

,Causa namque tui paterer discrimina belli;

Daviticę citare melodiam prosequar ipse.

940 Imminuentur atre sollemni carmine cure.

Tu tamen incipias, cantu superabo Syrenas.

,Omne genus hominum vincam clangore tubarum,

Non iuxta solitum Francorum corniferorum.

Est mihi psalterium, quod erat David, dechacordum.

945 Asaph me docuit, qui psalmos fingere iuvit.

Incipe, si quid habes; pascales psallito laudes.

,Est hinc longa via, qua perveniatur ad antra?

,Hinc cernes summi volitando culmina tecti.

Flegmate detersis rostris cantuque paratis

950 Excuciunt rapidas coniuncto federe pennas. 
But since your heart is vacillating, I reject what you say as untrue.

Produce a witness whom I could believe as veracious."

(Philomena) "That I should repeat something more or spin out long

[periods of time again?

Does this happy event not remain for you that the first created man,

[driven

920 From heaven's splendor, is again joined with the blissful denizens of What greater joys do you want us to treat [heaven?

Than that the threshold of the gates of Paradise is opened?"

(Panther to Philomena) "Let the probing of such secrets be enough now.

Leave the threshold of the stately building now, leave it."

They, moist with tears, soiled with the dust of the earth,

At the order of the panther go together to bathe in the stream.

When the two singing friends, having washed in the Gironde river,

Retrace their steps and strive to visit the two kings,

Wet, hungry, and tired from the song they have sung,

930 They perch upon the branches of a beech with but a single thought.

While they arrange their feathers and smooth their down in the sun,

A parrot approaches and asks if the king has recovered;

A swan is also there to learn of the life of the invalid.

To the inquirer the bird answers this much:

"A paschal feast of resurrection is to be celebrated in the lofty palace

In which the two kings reside and feast with their soldiery;

I ask you, express with us the joy of your voices."

(Parrot) "For your sake I would endure the trials of war;

I myself will accompany the tune of the harp of David.

940 Dark cares will be lessened through the solemn song.

Now you begin, and I will surpass the Sirens with my singing."

(Swan) "The whole race of men will I conquer with the blare of the

Far surpassing the custom of the horn-bearing Franks. [trumpets,

I have a psalter, which was David's, of ten strings,

Asaph taught me, who helped fashion the psalms.

Begin if you have something; sing the paschal praises to the cithara."

[Parrot] "Is it a long way from here before we reach the royal cave?"

(Philomena) "From here you can see in flight the top of the highest roof."

With beaks freed of sluggishness and prepared for song

950 They spread their rapid wings in a joint endeavor. 
Nec mora, conveniunt, pinne fastigia prendunt.

Previa fit merula, pardo offert hec nova monstra;

Qui surgit subitus, longinquos osculaturus,

Visis arrisit, raros sibi federe iunxit.

psitacvs. $\quad 955$,Oceano positis regis fit fama iacentis;

Est quia divinum, languentis visere stratum, Compuncti lacrimis palmis deflevimus artis.

Ordine confuso lustravimus aere denso;

Quo via sit nobis, invidit semita nubis,

960 Donec Burdigalis〈sub〉 opace tempore noctis

Fit strepitus plebis matutinos imno petentis,

Namque Severini celebrabat festa beati.

Cumque fatigati moraremur ad atria sancti,

Cum reliquo vulgo redibentes cantica Christo,

965 Mox aurora rubens maturat pellere nubes.

Inde recedentes invenimus hasce sorores,

Conductu quarum quesitum invenimus egrum.

Ergo te petimus, sis nobis fixus amicus.

Diceris a cunctis clari lux altera solis,

970 Te duce ducamur, te preduce post revehamur.

Hec filomela soror, nimius quam detinet ardor

Subpeditare tibi servireque corde fideli,

Nos prece blanditur, ut Christi pascha colatur:

Comprime tu strepitum, nostrum quoque dirige gressum.

975 It, redit, attactu leni introducere cepit;

Protinus intrantes hoc ponunt ordine laudes:

,Salve festa dies, quam credens magnificat plebs!‘

Hoc post odecolon grecissant Kirrie eleison,

Fit vox omnigenum volucrum pecudumque ferarum,

980 Multiplicique modo sacra cantio personat antro.

Manes devicti lugent sua damna revolvi;

Cetera gesta dei, recolit quę pagina libri,

Lingua Iudaica ructant Grecaque Latina. 
Without delay they join and land on the top of the parapet.

The blackbird leads the way and shows these new wonderful birds to the He rises immediately and kisses the strangers, [panther; He smiled at them when he saw them and joined the rare guests to himself [in a pact of friendship.

(Parrot) "As far as those living at the Ocean the report of the sick king is [carried;

Because it is a divine order to visit the bed of the invalid, We, blinded by tears, wept and wrung our hands.

In confused order we traversed the dense fog;

The path of the cloud jealously hid the place where our road is,

960 Until at Bordeaux, in the dead of night,

There is a commotion of people intoning the matins,

For they were celebrating the feast of blessed Severinus.

When we, fatigued, tarried in the hallway of the temple,

Repeating songs to Christ with the rest of the populace,

Ruby Aurora already hastens to drive away the clouds.

Returning from there we found these two sisters

And under their guidance discovered the sick man whom we were seeking.

Therefore we beg you, be a steadfast friend to us.

You will be called by all the second light of the dazzling sun,

970 Let us be guided under your leadership and then let us return with you

[leading the way.

This sister nightingale, whom too much zeal urges

To help you and to serve you with a loyal heart,

Entices us with prayer to celebrate Christ's Easter:

Suppress the commotion and direct our steps too."

He (the panther) goes, he returns, he proceeds to lead them with gentle

Entering forthwith, they utter praises in this manner: [touch;

"Hail, festive day, which the believing people celebrate!"

After this paean they exclaim Kyrie Eleison in Greek,

The voices of every kind of bird and of wild beasts are heard,

980 And the sacred song resounds in the cave in manifold fashion,

Souls of the dead (in hell - with the devil) mourn that their damnation is

[repeated;

Other acts of God which the page of the Book rehearses

They relate in Jewish, Greek and Latin tongues. 
Vt complent apices, quos scribit virgo Iohannes,

985 Aptant he celeres herboso cespite sedes.

PSITACvs. Scrutor raucisona, num sit quoque fracta lagena,

Quod mihi poscenti non dantur pocula vini,

Nam neque divitibus contingunt gaudia solis."

LEO PSITACO

,Apponas aliquam, si nosti forte, medelam.

PSITACVS.

990 ,Nil nisi lene decet vacuis committere venis."

LEO PSITACO.

,Nil ego pretulerim iucundo sanus amico."

PSITACVS.

,Oderunt hilarem mesti tristemque iocosi.“

Nam leo, cum vino incaluit, mox talia dixit:

,Vulpes sensata prudenter rexerat ista

995 Meque meamque domum super omne revexit honestum,

Corpus languentis confoverat igne salutis,

Seminecem membris nec cessat reddere mensis.

Hec petiit pardum post me regnare secundum,

Istius ad votum regem sacravimus istum,

1000 Nam mea sint pardi; quẹ pardi, proxima vulpi.‘

LEO PARDo. $\quad$,Vulpem versutam lateri ne dempseris umquam!

Tunc versuta dolis de tanto munere regis

Tristatur facie, quamquam letetur ad omne.

PARDVS LeONI. $\quad$,Tristior est solito, me cernit lumine torto.

LEO PARDO. 1005 ,Si quid vult proprium, verum non celet amicum.

vvLPes. $\quad$ Est specus in silvis celsi sub culmine montis,

Hanc mihi posco dari facto munimine scripti.

Confirmant reges, petiit quod subdola vulpes,

Testibus ab tantis firmatur cautio vulpis.

LVPvs Lvtro. 1010 ,Hec est ista specus, data tunc sub regibus illis;

Pro facto scelere, quod vulpes gessit inique

Adversus proavum, tultum fuerat sibi castrum.

Successit soboles, successit tortus et heres.'

LVTER.

,Delinqunt patres, solvunt delicta sequaces. 
As soon as they have finished the gospel of the virgin John (the last They quickly arrange their seats on the grassy sod.

(Parrot) "I ask with a hoarse voice whether the flask is broken

Because no beakers of wine are given to me at my bidding,

For the joys of the sun do not fall to the rich (alone)."

(Lion to parrot) "Bring some remedy if perchance you know one."

990 (Parrot) "Nothing but a gentle remedy is proper to supply to empty veins." (Lion to parrot) "If I were well I would like nothing better than an [amiable friend."

(Parrot) "The sad hate the cheerful man and the happy ones the sad man." Then the lion, when he was heated with wine, spoke as follows:

"The shrewd fox had arranged these matters prudently And has restored me and my house to the height of extreme honor, He has refreshed the body of me, the sick man, with the glow of health, And he does not tire of giving me, half dead in my limbs, back to the [joys of the table.

He has asked that the panther be assigned to rule as my successor, And according to his wish we have consecrated him as king,

1000 Now my kingdom shall pass to the panther, and after the panther, to the (Lion to panther) "Never leave the shrewd fox from your side." [fox." Then the fox skilful in stratagems, takes on a sad mien

Because of so much favor of the king, although he is happy in everything. (Panther to lion) "He is sadder than usual, he looks at me askance."

(Lion to panther) "If he wishes anything for himself, he should not [conceal it from his true friend."

(Fox) "There is a cave (castle?) in the woods under the brow of a high hill. I ask that I be given this cave with a written deed of enfeoffment."

The kings (lion and panther) confirm what the crafty fox petitions, And through such witnesses the deed is assured to the fox.

1010 (Wolf of "outer fable" to otter) "This is the same cave given (to the fox) [at that time under those kings;

Because of the committed crime which the fox perpetrated unjustly Against my ancestor, the castle was taken away from him.

A descendant has stepped into his place, and a perverted heir has [succeeded him."

(Otter) "The fathers commit sin, and their descendants make good the [wrongs. 
1015 Cetera prosequere, quę sint insignia cęne?*

LVPVS. ,Tolluntur lances, longinquus vescitur hospes.'

PARDVS VvLPI. ,Prevideas, ne turpe toral, nec sordida mappa, Sordidus aut dapifer nares conruget edentum; Magna movet stomacho fastidia, seu puer unctis

1020 Tractavit calicem manibus, dum furta ligurrit, Sive gravis veteri cratere limus adhesit.

Pocula miscentem nutritum pone clientem; Casta serenatis impone cibaria mensis, Ponantur nuclei corilorum robore nati, 1025 Persica cum cerasis, quectonia mixtaque fragis, Poma Geroldinga, quę detulit hec philomela; Precoqua purgetur claris in fontibus uva; $\mathrm{Vt}$ dabis elixa, confestim dentur et assa. Accubet et reliquum servum pecus ad comedendum.'

vvLPES. $\quad 1030$,Insistam cunctis, quę monstrat sermo iubentis.' Sublato disco surgens fera sistitur antro.

PSITACyS.

,Precipiat dominus, licitos repetat fera cursus.

,Accipite ergo omnes auresque advertite cordis.

Gratia sit vobis, quod sic mihi condoluistis;

1035 Exitibus vestris nullus dominetur ut hostis

Finibus in cunctis, latus qua tenditur orbis. Potio defertur, temulenti quique vehuntur, Pace salutantis discedit concio castris.

Non calamus referet, quę regis iussio prebet.

1040 Tunc vaga prosiliit frenis natura remotis, Seque per immensas diffundunt agmina silvas. Mox magni parvique lupum lusere gavisi, Accessit lete turbe glomeratio tante; Exprobat in facie, quẹ sit custodia lingue, 1045 Informat scriptis, quę sit cautela bilinguis: ,Dentibus infrendis, vane tua labra voraris; 
Tell me the rest, what are the features of the meal?"

(Wolf) "The plates are removed, the host from afar feasts." (Panther to fox) "See to it that no filthy cover, no dirty napkin Nor untidy butler shall cause the diners to turn up their noses; It gives one's stomach great nausea when a scullion has handled

1020 A cup with greasy hands while he licks up what he has pilfered, Or when a heavy layer of filth clings to an old crater.

Let a well-trained retainer mix the drinks;

Place pure food on well-ordered tables,

Let nuts be brought, grown on the hazel-nut tree,

Peaches with cherries, and quinces mixed with strawberries,

Apples from Gerolding which this Philomela has brought;

Let the early ripe grape be cleaned in pure spring water;

Let fried food be given straightway, as you will also offer boiled dishes. And let the rest of the serving herd too take their places for the joint [meal."

1030 (Fox) "I will strive to do all the things that the words of the master direct." After the tables are taken away, the beasts rise and are arrayed before the [cave.

(Parrot) "Let the master instruct them, let the beasts retrace the course [permitted to them." (Lion) "All of you now receive (what I have to say) and lend the ears of [your heart.

Thanks be to you that you have taken such pity on me;

As you go out from here, may no one lord it over you as an enemy

In any place where the wide earth stretches."

The goblets are removed, and tipsy they all depart,

And in the peacefulness of the king's farewell the assembly leaves the [castle.

My pen does not report what the king's command brings (how it works

1040 Then erratic nature lept forward when the reins are relaxed, [out). And the columns pour forth through the vast forests.

Soon large and small took delight in mocking the wolf, And the throng of such happy creatures came closer to him;

They show by their expression what it means to watch one's tongue, And put on paper what two-faced shrewdness means:

"With gnashing teeth you bite your lips in vain; 
Te tua culpa premit; tu, dum tua navis in alto est, Hoc age, ne mutata retrorsum te ferat aura; Inspicit omnipotens actus, qua mente regantur,

1050 Nam semel emissum volat inrevocabile verbum. Hic dolus est, inimice, tuus, concepta simultas! Multifluisque diem verbis ducendo fatigant.

PSITACVS LEONI.

PSITACVS PHILOMELE.

VVLPES.

PARDVS.

LEO SPITACO.

PHILOMELA.

,Non capiam quicquam rediens nec lesero quemquam.

Dum vacat ergo tibi, sine causa vivere noli;

1055 Quod cupide poscis, mature plene relinquis.

Disce miser tandem, si vis contemnere mortem, Quod, ceu flos feni, sic omnis gloria mundi.

Cur tibi condis opes, cur cecos queris honores?

Cur putridis multam te nutris vermibus escam?

1060 Diligis hunc mundum, proprium qui fallit amicum!

,Quod das consilium, quo possim prendere somnum?

Quę mihi sunt regno, vadens hinc desero pardo.'

,Plectris dulcisonis curarum semina pellis;

Tu cum sis, quod ego, fortassis cautior ullo,

1065 Nunc in amore mei comportes somnia regi.

,Quod petis, hoc peragam; causam non respuo iussam.

Rex ubi melliti captus dulcedine plectri

Obdormire parat, vulpes differre laborat.

,Naturale tibi confirmat pagina libri,

1070 Quod dormis triduo; sed quid manet hospes in antro?

,Defessi veniunt: pausent modicum atque redibunt."

Expleto triduo mox rex discessit ab antro

Et Svvarzvvalt petiit, Alemannica rura revisit,

Diviciasque domus usurpat mox sibi pardus.

1075 Cignus Nortmannos possedit, psitacus Indos,

Pardus duxit aves ad partes occiduales.

His ita dispersis sic fit migracio vulpis:

Ad proavum tendit, probrosa epitafia scribit: 
Your guilt oppresses you; while your ship is on the seas you Must take care lest a change of breeze drive you backwards;

The All-Powerful One beholds all deeds and (sees) by what spirit they are 1050 And once uttered, the irrevocable word flies forth.

[guided, This is (the result of) your deceit, my foe, the hatred you have conceived!" Thus spending their time, the multitude draws out the day with many[flowing words.

(Parrot to lion) "I shall not take anything when I go, and will not harm [anyone.

And so long as you have the opportunity do not live without purpose; What you desire eagerly, you will leave completely in due time.

Learn, wretch, at last, if you wish to look down upon death, That all the glory of the world is like the bloom of hay.

Why do you accumulate wealth, why do you seek useless honors?

Why nourish yourself as rich food for worms of decay?

1060 You love this world which deceives its very own friend!"

(Lion to parrot) "What advice do you give by which I could find sleep?

What is mine as a realm I shall leave to the panther when I depart from

[here."

(Parrot to Philomele) "With sweet sounds of the cithara you banish the [seeds of care;

Since you are, perhaps, like myself, more clever than the rest,

Put the king to sleep as a favor to me."

(Philomela) "What you request I will carry out; I will not scorn the [matter entrusted to me."

When the king, captivated by the sweetness of the honeyed cithara, Prepares to go asleep, the fox strives to scatter (the crowd).

(Fox) "The page of the book assures what is natural for you,

1070 That you will sleep three days; but why does the guest stay in the cave?" (Panther) "They came tired: they will rest a little and then go."

When the three days were expired, the king soon departed from the cave And sought the Black Forest, revisiting the Alemannic regions, And straightway the panther takes over the treasures of the house.

The swan possessed the Northmen, the parrot the Hindus, The panther led the birds to the western parts.

When they were scattered, the journey of the fox was begun as follows: He goes to my ancestor and writes this shameful epitaph: 
,Conveniens curtim parium venerare cohortem;

1080 Flecte caput tumidum susceptus sede potentum, Premeditare prius, quę 〈des〉 enigmata, cautus. Rarus in eloquio, sollers sermone serendo, Falsa loqui fugito, reseratis auribus esto, Quid de quoque viro, et cui dicas, sepe videto, 1085 Sepe rogus modicus comburit culmina saltus, Nam neglecta solent incendia sumere vires; Officio lingue nullum frustreris honore, Nam tua res agitur, paries cum proximus ardet. Sic tibimet vere continget gratia fame,

1090 Sic sic magnus eris, eternum nomen habebis; Ipse bilinguis eras, nepti tormenta parabas, Nec minus optati quam facti pena luenda est: Vermibus et vespis optabilis esca iacebis. ‘ Inde petens castrum duxit secum leopardum, 1095 Nuntius ut regis sibi det munimina pacis. Talibus a culpis facta est expulsio vulpis. Sufficiat dictis de tanto tramite vulpis." ,Vere sufficeret, si non fortassis adesset. Ast bene fecisti, quod nobis sic reserasti 1100 Tecta diu, planis nudans archana loquelis. Esse potest ab re, quod tardat concio turbe; Commissus sanctis scrutabor, quid gerat hostis." Luter adit collem, qui cingit de prope rupem, Aspectat vulpem pitacia scripta vehentem

1105 Testibus appositis, fuerant qui solibus illis.

Cetus erat fortis, conclamans vocibus altis: ,Regis preceptum numquam frustretur inultum! Passeribus prosit, qui regis iussa fefellit, Sublaterans quemquam; non hoc sibi proderit umquam, 1110 Si scandit fraude, mox mistica seminat ore. Perplexo morsus resupinat corde lupinos, Occultans animum, certat subvertere iustum. Mortis hic est amus, viroso escamine tectus, Propinat mortem, dum fingit ferre salutem.

1115 Fraudem, quam fecit, vicinam confore scibit; 
(Epitaph) "When you come to court, pay respect to the gathering of peers;

1080 Bow your proud head when received at the seat of the mighty,

And prudently ponder first what obscure answers to give.

Sparing in utterance, clever in directing conversation,

Avoid speaking falsehood, but have open ears,

Often take care what you say about any man, and to whom you say it, Often a moderate bonfire will burn the top of a wooded hill,

For neglected fires are wont to spread;

With the action of your tongue never cheat anyone of his good name,

For your interest is at stake, when the neighbor's wall is afire.

Thus the favor of true fame will fall to your lot,

1090 Thus, thus you will be great and have a lasting name.

You yourself were two-faced, you prepared tortures for your nephew,

And punishment should be meted out no less for a wish than for a deed:

You will lie as a desirable prey for worms and wasps."

From here he made for his castle and took with him the leopard,

That as nuncio of the king he might give him safe-conduct.

On account of such deeds the expulsion of the fox took place.

Let these words be enough about his great wanderings.

(Otter) "The story would truly suffice, if he were perchance not present.

Yet you have done well in thus disclosing to us

1100 What was long concealed, baring secrets with plain words.

It can be advantageous that the gathering of the crowd is delayed;

Bound to holy vows, I will investigate what the foe is doing."

The otter approaches the hill which is close by the cliff

And sees the fox bearing the written parchment

With the witnesses of those days added.

There was a large crowd which shouted with high voices:

"Never shall disregard of the king's will go unavenged!

Let it be to the sparrows' advantage if anyone frustrates the orders of the

And defames (wheedles?) a man; this will not avail him aught [king

1110 If he rises through fraud and soon spreads sinister charges with his mouth.

With a false heart he turns about and snaps at the pursuer,

Concealing his intention, he strives to overthrow the righteous one.

$\mathrm{He}$ is the hook of death, hidden by poisonous bait,

While he feigns to bring safety, he pledges death.

He will learn that the deceit which he wrought is near at hand for him too. 
Quod sine lege stetit, vere sine lege peribit.

Hos repetens ludos enutriat in cruce corvos,

Et famuli nequam vincti mittantur Ylerdam.

Vestitura dati confestim redditur illi.'

1120 Audierat proceres istas imponere leges;

Territus hisce minis, correptus mente furoris,

Omnia, quę vidit, relegens ex ordine pandit,

Hortaturque lupum, concedat abire iuvencum.

LVPVS.

,Non hominem vereor, nec vulpis me quatit horror."

LVTER.

1125 ,Consilium refugis, cervicibus imminet ensis,

Iudicio mortis ad presens tu capieris,

Quique tui capti, vincti morientur et illi.

Auxilium queris: querendum tempore pacis;

Dicere et audire et meliori credere non vis,

1130 Non magni pendis habitum vultumque potentis;

Principibus placuisse viris non ultima laus est.

Gratia tantorum tultum reddet sibi castrum,

Nec magno aut parvo leti fuga nulla erit antro.

Luter discipulus, collis de culmine lapsus,

1135 Formidans hostes possessaque castra relinquens,

Horrens exitium, fluvii se mersit ad imum.

Ericio, latis solito considere cellis,

Abdere se silici cure fuit atque labori.

Curritur ad castra, sola latrante licisca,

1140 Invadunt castrum Franco de milite castum.

vVLPES. $\quad 1142$,Hic est aut nusquam, quod querimus: hic latet hostis.

Cernitis en patruum? quid agis, dulcissime rerum?

Incolomi capite es, quin cano flore reluces,

1145 Formosus facie, sura, pede, dente, lacerto,

Candidus, et talos a vertice pulcher ad imos.

Tu patre preclaro nutritus pectore casto,

Certum est, ingenuos habeas ditesque parentes.

In regum numero regnas Cuonone secundus,

1150 Precellis cunctos famosis patribus ortos,

Litterulis doctus, multis et honoribus auctus. 
What has stood without law will truly perish without it.

Repeating such exploits, he shall be food for ravens as he hangs on a cross, And his evil retainers shall be sent in bonds to Ilerda.

The fief will immediately be given back to him."

1120 The otter had heard the chiefs impose these rules;

Frightened by these threats and seized with madness,

He repeats all he had seen and spreads it out in order

And urges the wolf to let the calf go.

(Wolf) "I do not fear human kind, nor does terror of the fox shake me."

(Otter) "You shun advice, (although) the sword threatens your neck,

You will be seized forthwith under judgment of death,

And all your fellow captives will die too, bound as prisoners.

You seek help; it should have been sought in quiet times;

You do not wish to speak and to listen and to believe what is better,

1130 And you do not deem important the mood and the mien of the mighty;

It is not the meanest praise if one has satisfied men of rank.

The favor of such men will restore (to the fox) the lost castle,

Nor will there be any escape from death in a large cave (castle?) or in a small one."

The otter, the pupil (of the wolf), falling from the top of the hill, Dreading the enemy and leaving the castle which had been possessed, And fearing destruction, dove to the bottom of the river.

The badger, accustomed to dwell in spacious chambers, Made it his care and toil to hide amid the gravel.

Then a charge is made (by the foe) on the camp, accompanied only by [the barking of the hound,

1140 And they invade the camp, cleared of Frankish men.

1142 (Fox) "Here or nowhere is what we seek: here the foe hides.

Do you see your uncle? How are you, sweetest of creatures?

You carry your head well, yes, you are resplendent in a gray sheen, Attractive in features, thighs, feet, teeth, and arms,

Spotless and good-looking from head to foot.

You were reared by an illustrious father and are of a pure heart,

It is certain that you have well-born and rich parents.

In the list of kings you rule second to Conrad,

1150 And excel all those born of famous sires,

Learned in letters and adorned with many honors. 
Obiciet nemo sordes tibi, quas mihi multi.

Qui tibi complaceo, qui turpia vincis honesto?

Susum scande, pater: mirabitur unus et alter

1155 Artus egregios generoso in corpore sculptos;

Mentior at si quid, merdis caput inquiner albis.

1141 Alloquiis vulpis seducitur atque querelis.

1157 Conservus vilis, quem tardat acuta securis, Dum lupus ascendit, obiecta repagula traxit, Sic foras exiliit, matrem cum patre reposcit,

1160 Vbera cum suxit, matri letatus inhesit.

Protulit exemplar, veri quod lucet ad instar:

,Non semper feriet, quodcumque minabitur, arcus.'

At lupus a tauro trunco configitur alto.

Vulpes hunc gemino collaudat pollice ludum,

EPITAPHIVM.

1165 Hęc pravo scriptum predoni perhibet aptum:

,Hoc legimus scriptum, credamus et esse probatum:

Ve qui predaris, quoniam predaberis ipse!

Mercatur mortem, qui fraudis diliget artem,

$\mathrm{Nec}$ capiet risum, qui sic sectatur iniqum.

1170 In te se discat, qui iuste vivere tardat!"

Mox patrios ingressa lares eliminat hostes,

Nam murum scandit, caris confratribus inquid:

,Divitis omne bonum, si non fuerit stabilitum

Consilio, racione, modo, solet adnichilari,

1175 Aeque neglectum pueris senibusve nocivum.

Que maior pestis, heu, quidve nocentius istis

Aspidibus, colubris, basiliscis atque chelidris?

Et tamen hos fertur superare domesticus hostis.

Quid tardat sapiens, forsan si ceperit hostes,

1180 Ni liget ac cruciet, obstruso carcere damnet?

Compedibus tales num sub custode tenebit?

Moris erat, fortassis erit, dum quisque vigebit,

Si prece, si precio laxatur captio capto,

Obside suscepto seu firmo sit sacramento:

1185 Qui hos vocat ad cameras, piperatas porrigit escas,

Mollia strata iacit, quęcumque tacenda resolvit - 
No one will accuse you of meanness, as many do me.

How can I satisfy you who overcome evil with good?

Rise aloft, father; this one and that one will admire

Your splendid limbs sculptured on a noble body;

1156 If I tell a falsehood in anything, may my head be soiled with white

[excrement."

$1141 \mathrm{He}$ is allured by the blandishments and laments of the fox.

1157 While the wolf comes up, the vile fellow-slave (calf) whom the sharp ax Hinders, released the bolt which had locked the door, And thus the calf runs out, seeks his father and mother,

1160 And when he suckled his mother's breasts, he clung happily to her.

He offered an example which shines forth like the truth:

"The bow will not always strike what it aims at."

But the wolf is impaled by the bull on a high tree-trunk.

The fox applauds this as sport by turning down his two thumbs,

But he offers the low robber this fitting epitaph:

(Epitaph) "This we read in writing, and let us believe it is tried and true:

Woe on you who steal because you will yourself be robbed!

He bargains for death who is fond of the art of deceit,

Nor will he win a smile who thus pursues what is unjust.

1170 Whoever delays living righteously, let him see his future fate in you!"

Soon entering his native halls, he drives out the enemy

And climbs the wall and says to his dear compatriots:

"All the blessings of wealth, if not secured

By counsel, reason, moderation, are wont to be destroyed

And if neglected are equally harmful to young and old.

What greater pestilence, alas, and what is more injurious than those

Vipers, snakes, basilisks and water-serpents?

And yet an enemy in the house is said to surpass them.

Why does the wise man delay, when by chance he has caught his enemies,

1180 And not bind and crucify them, and condemn them to a dark dungeon?

Will he not hold them in fetters under guard?

It was the custom, and will perhaps be as long as men live,

That by plea, or by price the captive is freed of imprisonment

Through the acceptance of a hostage or through a binding oath:

If he calls them to his chambers and offers spiced food,

Spreads a soft bed and reveals all secrets - 
Nulla catena premit, nec ferrea passio cogit -

Excors, follus, ebes, abnormis, garrulus idem est,

Et perit ut lupus hic, condigno fine perhemptus,

1190 Nam multi pereunt, quia sensu vivere nolunt.

Non iactu lapidis nec iacto missile quovis

Captio fit castri tanti sine cęde peculii:

Ingenii sensus prudentum fortis et astus

Milibus armatis cicius dominatur inhermis.

1195 Credite, consocii, me visit gratia Christi.

Conservate fidem, nodosam pellite fraudem,

Subveniat frater fratri pro posse fideli!

Talibus hosce monens Christo mandaverat omnes.

Dum redeunt pariter, affatur talia mater:

1200 ,Cur non, nate, refers, que sevus fecerit hospes?

vitvLvs.

,O mater, peccas, dum tristia metra retractas;

Tedet sacrilegas antri percurrere curas;

Has si plus refero, fastidia magna parabo:

Dulce sonat modicum, confert fastidia magnum.

1205 Pertuleram triste, quod sic tardastis utrique.

Prorsus iucundam noctem produximus istam:

Possedi sotium, qui fletum fudit amarun,

Pro me sepe rogans lacrimas eduxit amaras,

Luter ridiculus famoso est nomine dictus,

1210 Attrectans amnes, piscosi gurgitis heres.

Hicce meis oculis detersit signa meroris

Sub noctem gelidumque foco calefactat amicum.

Non tamen adversis insomnia duximus austris,

Me Bacho satiat, quin lenia verba propinat.

1215 Ericium vafrum, servis de pluribus unum, Instruit Herodes vitulinas scindere carnes, Qui dixit vitulum festivum pasca futurum, Per se sumendum, nulli per frusta secandum; Ad iugulum tantum ferrum reddebat acutum,

1220 Me cupiens miserum morsu lacerare ferino. Laus domino, qui me salvarat dente lupino!

Sanus et incolumis maternis deferor ulnis.

Sit nomen sanctum Christi domini benedictum! 
No chain oppresses them, no iron torture compels them Simple, foolish, dull, abnormal, and talkative he is, And he will perish like this wolf, doomed to a deserved end,

1190 For many perish because they refuse to live sensibly.

Not with the hurling of a rock nor with the throwing of any missile Is the capture of such a castle possible without the death of cattle:

The bold intelligence and the stratagem of clever men,

Though unarmed, prevail more quickly than a thousand who are under

Believe me, comrades, the mercy of Christ comes over me. [arms.

Preserve faith and expel knotty deceit,

And let brother help loyal brother as much as he can!"

Admonishing them with such words, he commended them all to Christ.

As they return home together, the mother speaks such words:

1200 "Why do you not relate, child, what the dreadful host did?"

(Calf) "O mother, you do wrong in bringing up the sad song again;

It is repugnant to me to go through the infamous anxieties of the cave;

If I report them again I will cause great loathing:

Not much of it sounds sweet, it causes disgust to a high degree.

I had endured a sad lot, which you two have brought to an end,

We spent that night quite happily:

I had an ally who wept bitterly,

Often begging for me, he shed bitter tears,

The fun-loving otter he is called, famous of name,

1210 Splashing about in the water, the heir of the fishy flood.

He wiped from my eyes the signs of fear

And in the night warmed his cold friend at the hearth.

In spite of everything we did not lie sleepless as we faced the south wind, He appeased me with Bacchus and pledged gentle words.

The shrewd badger, one of the many servants,

Was instructed by Herod to cut up the flesh of the calf,

And Herod said that the calf would be a festive Easter dish,

To be consumed by himself and to be cut in pieces for no other;

To my throat he was setting the huge knife, which was sharp,

1220 Desiring to tear me wretch apart with a wild bite.

Praise be to the Lord who saved me from the teeth of the wolf!

I am brought hale and safe to the arms of my mother.

May the holy name of Christ the Lord be blessed!" 
Versus milleni centeni septuageni:

1225 Verum operi longo fas est obrepere somnum,

Nimirum sapere est abiectis utile nugis

Et tempestivum psalmis concedere ludum;

Iratus pariter, ieiunis dentibus acer,

Sermonem claudam, verbum non amplius addam. 
Verses one thousand one hundred seventy:

In truth it is natural for sleep to overcome a man over a work that is long, And indeed it is useful (for me) to be wise and to lay trifles aside And time to give up toying in favor of psalms;

Angry (at myself) at the same time, and sensitive with teeth that have felt

I shall conclude my talk and add not another word. [no food, 



\section{APPENDIX}

Aegrum fama fuit...

This little fable in elegiac distichs, often but not certainly ascribed to Paulus Diaconus, dates from the late eighth century. Published in Mon. Germ. Hist., Poetae 1, 62-64, it assumes importance as an early forerunner of the Ecbasis, although hardly known to the author of the latter. It is conjectured that tibi in line 67 refers to Charlemagne (i.e. Charles I) when he was still only king of the Franks. The poem is discussed above in the Introduction, section 4. Several Virgilian echoes are found in it. Line 33 echoes Ecl. 5, 62: voces ad sidera iactant; Aen. 2, 222: clamores...ad sidera tollit; and ibid. 11,878: clamorem ad caeli sidera tollunt. Line 43 reminds one of Aen. 4,563: nefas in pectore versat, and of Georg. 4, 83: animos angusto in pectore versant. Servulus in 1.67 is also used by Paulus in a letter to Charlemagne (Mon. Germ. Hist., Script. rer. langobard. 19, n. 5.). 
Aegrum fama fuit quondam iacuisse leonem

Peneque supremos iam tenuisse dies.

Iste feras dum rumor adit mestissimus omnes,

Regem namque suum intoleranda pati,

Concurrunt flentes cunctae medicosque vocantes,

$\mathrm{Ne}$ careant tanto principis auxilio.

His aderant bubali, magni quoque corporis uri,

Asper adest taurus, affuerantque boves,

Discolor et pardus necnon pariter platocervus,

10 Hic sonipes pariter hoc comitatus iter.

His nec defuerant monstrantes cornua cervi,

Capriolique simul, caprigenumque pecus;

Dentibus hic aper est fulgentibus, asper et ursus

Unguibus haud sectis, hic lepus atque lupus.

Huc veniunt linces, huc confluxere bidentes,

Iungunturque canes atque simul catuli.

Vulpis sola tamen turmis non affuit istis,

$\mathrm{Nec}$ dignata suum visere nam dominum.

Has tunc ante alios voces emittere fertur

20 Ursus et has iterum sic iterare minas:

,O rex magne, potens, princeps invicte ferarum,

Auribus haec placidis suscipe verba tuis

Audiat atque cohors tota haec quae subdita magno,

$O$ rex iuste, tuo noscitur imperio.

Quae tam dira fuit vulpi dementia quaeve

Tantillam potuit ira subisse feram,

Ut regem, quem cuncta sibi pleps subdita visit,

Hunc haec sola quidem non adiisse velit?

Magna est ista quidem vulpis protervia mentis,

30 Atque decet magnis subdier illa malis.

Haec dum dicta refert ursus, rex omnibus inquit:

,Iam moritura cito dilacerata cadat!"

Tunc pleps tota simul voces ad sidera tollit:

,Iustum iudicium principis atque bonum.

Hoc vulpi innotuit, se quae in plurima vertit,

Atque diu notos praeparat ipsa dolos:

Indumenta pedum multa et conscissa requirit 
Once the rumor went about that the lion lay ill

And had almost reached his last days.

When this most sad report reaches all the beasts,

Namely that their king is suffering unbearable pain,

They all come together weeping and calling for physicians,

So that they may not be without the great help of their chief.

Here were present gazelles and aurochs of huge body,

There is present the impetuous steer, and there were the oxen,

And the spotted panther as well as the long-horned stag,

10 Here was the steed too which had gone along on this road.

Nor were there lacking among them deer showing their horns,

And the roebuck as well, and the goat family;

Here is the boar with flashing teeth, and the fierce bear

With uncut claws, here the hare and the wolf.

Hither come the lynxes, hither the sheep gathered in flocks,

The dogs assemble, and at the same time the kittens.

However, the fox alone was not present among the swarms,

For he did not deem it worth his while to look up his master.

Then the bear is said to express these words in the presence of the rest

20 And to repeat the following threats several times:

"O great king, mighty one, indomitable ruler of the beasts,

Take up these words with your gentle ears

And let this whole gathering hear, which is subject,

As is well known, to your powerful rule, o just king,

What madness so terrible has come over the fox, and what

Wrath could steal its way into so small an animal

That he alone should not wish to approach

This king whom all the subject people visit?

Great indeed is this insolent spirit of the fox,

30 And it is meet that he be visited with great evil."

When the bear brings forth these words, the king says to all:

"He shall immediately be condemned to death and fall, torn to shreds."

Then all the folk raise their voices at the same time to the stars:

"Just and good is the judgment of our chief."

This became known to the fox who turns his attention to many things

And prepares his long known stratagems:

He seeks out much footwear which is torn to pieces 
Inponensque humeris regia castra petit.

Quam rex dum vidit, placato pectore risit,

40 Expectatque diu quid malefida velit.

Cumque ante ora ducum constaret, rex prior inquit:

,Quid moritura feres, quae lanianda venis?

Illa diu trepidans, timidoque in pectore versans

Haec subiecta refert praecogitata cito:

,Rex pie, rex clemens, rex invictissime noster, Accipe nunc animo quae tibi dicta fero.

Haec dum namque vias terrarum lustro per omnes

Indumenta scidi ob studium medici,

Qui posset regis magno succurrere morbo,

50 Atque tuis magnam demere mestitiam.

Tandem praecipuum medicum vix inveniebam,

Sed tibi, rex, vereor dicere quae docuit."

Rex quoque ait: ,Si vera refers, dulcissima vulpis,

Dic mihi quid citius dixerit hic medicus.'

Vulpis ad haec ursi non immemor improba dixit:

,Cautius haec famulae suscipe verba tuae:

Ursino si te possum circumdare tergo,

Non mora, languor abit, sanaque vita redit.

Continuo iussu domini distenditur ursus

60 A sociis propriis detrahiturque cutis.

Qua dum gestirent obducere pelle leonem,

Aufugit penitus languidus ille dolor.

At cum post ursum vulpis sic corpore nudum

Viderat, haec laetis dicta refert animis:

,Quis dedit, urse pater, capite hanc gestare tyaram,

Et manicas vestris quis dedit has manibus?"

Servulus ecce tuus depromit hos tibi versus:

Fabula quid possit ista require valens. 
And, placing it upon his shoulders, looks up the castle of the king.

When the king saw this he laughed with a placated heart

40 And waits long to see what the insidious fellow wants.

And when he stood before the faces of the princes, the king was first to

[speak:

"What do you bring who are supposed to die, who come to be torn to

[shreds?"

He, after trembling a long time and pondering in his fearful breast, Quickly brings forth, full of submission, these words that he has well [prepared:

"Gentle king, merciful king, our most indomitable king,

Accept now in your heart the words that I bring you.

You see, while I wander over all the roads of the earth,

I tore these shoes in search of a physician

Who could offer a cure for the great illness of the king

50 And remove the great sadness of your people.

At last I found with much difficulty an excellent physician,

But I fear, o king, to tell you what he taught me."

Then the king speaks: "If you say the truth, dearest fox,

Tell me quickly what this physician said."

The wicked fox, not forgetful of the bear, said to this:

"Take up these words of your retainer cautiously:

If I can wrap around you the fur of the bear

Your illness will disappear without delay and your life will be healthy

Upon the immediate order of the master the bear is flayed

[again."

60 By his own companions and his pelt pulled off.

When they eagerly cover the lion with the pelt

That debilitating pain disappears forthwith

And when thereafter the fox had seen the bear so denuded in body,

He utters these words in a happy mood:

"Who, father bear, gave you this turban to wear on your head,

And who gave you these gloves for your hands?"

See, your humble servant brings you these verses.

Seek valiantly to ascertain what this fable may mean. 



\section{COMMENTARY}

15. ius, iura usually means custom, practice, wont, habit in the Ecbasis.

23. As Ekkehard 1. started writing verse in his early youth, so this writer, one hundred ycars later, started late. Here I disagree with Ehrismann. As he confesses, he actually has trouble with the sillabicos cursus, especially in the case of foreign (Greek) words: $c \bar{y}$ donia and crustūmia (1. 179), mĕlōdīa (1.893), but melŏdīa (1. 939). But simple Latin words too are sometimes wrongly accented: māsticat (1.89), ūtique (1.366), milītia (1.848), avīcula (1. 934).

24. This is literally true; the work is full of illogical changes of tense, often perhaps metri causa. Cf. 11. 81-82, 216, 226, 436-437, 782, and 1159-1160. The translation purposely retains this eccentricity.

28. I refer sibi to priscorum above.

42. There is no reason why recitas should not be taken literally; the work, or at least considerable parts of it, were probably meant to be recited. Indeed those portions where speakers are indicated were probably recited with the roles assigned to different speakers. On the blending of genres in the Ecbasis see the Introduction. non simplo stamine, 1. 68, must refer to this. The torta (twist, braid) panis (gen.) may be suggested by Exodus 29, 23; see also 1. 544, where Grimm reads panis tortis for pavis, turdis.

$69 \mathrm{f}$. I see no reason why this determination of time should be construed as being the date of composition, or a date connected remotely with the author's birth, as Voigt would have it. It is merely the date for the rara fabella (1.39) - an Easter story. But see also 11. 394 and 1026.

70. bis septima luna $=$ full moon.

97. forstrarius, a monastic official, here the wolf. The monastery as the scene of action is adhered to throughout.

110. superis is surprising since this does not seem to be a cento-quotation. But see 11.116 and 119.

111. In view of the meager fish and vegetable fare of the monastery, food was much in the minds of the monks and plays a dominant part in the Ecbasis.

112. But in 1.182 he speaks of seven years, using a Horatian quotation, and twice thereafter $(11.298,387)$ others also mention seven years. Is this an oversight on the author's part, or are the later references sly indications of the wolf's untrustworthiness?

116, 119. Since both lines are from Horace (1. 116 half from De arte poetica, 42, and partly from Sat. 2, 3, 206; 1. 119 from Sat. 2, 3, 288: dolores instead of labores), the pagan tone is less surprising. The marginal designations of speakers from this point on are in MS A.

132. On Henry see Introduction.

148. This verse, like 1. 335, may be taken from Mico's Florilegium, Poetae 3. It is originally 
from Serenus Sammonicus. Capsidile is accented wrongly in 335. See note on 1. 23 above.

152. Are Henry and Conrad both living? See Introduction.

$153 \mathrm{f}$. Both lines contain echoes of Hor. Carmina 1, 24, $11 \mathrm{f}$., and 2, 2, $23 \mathrm{f}$. The Carmina are used comparatively rarely (about 16 times) as against some 120 uses of the Satires and 75 of the Epistles. Even the brief ( $476 \mathrm{ll}$.) De arte poetica is used more frequently (20 times).

165. These fish are mentioned in the Mosella of Ausonius and the Halieutica of Ovid, but there is no evidence that the author used these works. The former e.g. mentions capito, barbus, salmo, mullus and gobio as found in the Moselle. See Grimm $327 \mathrm{ff}$. Both Waltharius and Ruodlieb also deal with fish. On these fish see also Voigt.

170, 172. Both Rabado (Rabadeau) and Petrosus are brooks in Lorraine. See Strecker ed. 45. I interpret ceto $(1.172)$ as coetu. Thus too coetus, 1. 173. But in 1.546 ceto is from cetus, whale. Strecker interprets Mosa (1.171) as the Meuse, Grimm as the Moselle.

$173 \mathrm{ff}$. The order of the lines was established by Grimm.

179. Crustumium was a Sabine town.

198. The first few words allude to the words in the canon of the Mass.

201. Germanic writers of Latin often invert to express the conditional. See also 11. 287 and 470.

203. Note the alliteration, as occasionally at other points.

220. "There ought always to be reading whilst the brethren eat at table." The Rule of St. Benedict translated with an Introduction by Cardinal Gasquet, London, 1925, Chap. 38, p. 71. The Reparatio lapsi, written in Greek by Chrysostomus in 369 and translated into Latin, admonishes a young friend, the later Bishop Theodorus of Mopsuestia in Cilicia, to a godly life, which is ever attainable for the repentant sinner.

236. Ms A has in ethere (aere in B) voces, but since this is a Virgilian echo (cf. Aen. 8, 70: ad aethera voces), Voigt's correction of what Strecker calls the "merkwürdige Lesart" ethere seems justified.

248. On this line and 1. 66 above see the Introduction; 1.308 echoes it.

251. One of the very rare (only three in all!) echoes of Terence: Adelph. 5, 3, 3. The others are 1.421: Phormio 4, 1, 20, and 1.707: Andria 1.1.2. One wonders if they are direct quotations. Certainly Terence was well known in the monasteries long before 1050 .

$256 \mathrm{ff}$. Strecker, comparing this passage with $11.156 \mathrm{ff}$., is puzzled by what he calls an inconsistency. In the earlier passage the wolf serves the calf, while here, Strecker thinks, the wolf talks as if the calf had served him. But in changing feret to foret in 1. 256 (which I accept) I believe Strecker has solved his own puzzle. What the wolf says is that the calf would not be innocent in mixing...

259. Had the monk who gave ms A the title Ecbasis observed this line, he might have used Excessus instead of the Greek expression. I interpret foris excessit literally as "ran away" and not, as Strecker does, p. 57: "begangen hat." See 1. 1159.

264. Strecker has one of his rare misprints - Index.

275. I follow Rathey: regamus (but not nec). The mss: negamus.

282. This line is an echo of one of the author's most popular writers, Prudentius, Contra Symmachum 2, 982: nec potis est tenuem telluri affigere fibram. But another now neglected reading of the Prudentius passage has affligere - an excellent example of how Ecbasis textual criticism can serve classical philology. Other examples: 1. 291, where Prudentius, Apotheosis, 
1. $395 \mathrm{f}$., has blandus in ore sapor, fragrans odor... sincera voluptas, but one ms has flagrans; 1. 725, which is identical with Ovid, Met. 10,559, except that the approved Ovid reading of the last word seems to be verbis, even though good MS authority supports labris; 1. 991, identical with Hor. Sat. 1, 5, 44, where contulerim is now preferred by editors to praetulerim of the Ecbasis. Certainly the mss of the Classics used by the Eckasis author have the sanction of old age. I do not think he usually quotes from memory.

284. Since spoken by the wolf, the East Franks are meant.

286. nunc was supplied by Grimm, who however recognized the possibility that this was a pentameter.

294. Strecker notes an echo of Martinus de Bracara, a Church writer.

$299 \mathrm{ff}$. von Winterfeld placed 299 after 301, but Otto Schumann deems this unnecessary. See his review of Strecker ed., p. $121 \mathrm{ff}$.

308. A refrain of 1.248.

$310 \mathrm{f}$. "No one without leave of the abbot shall presume to give or receive, or keep as his own, anything whatever... All things are to be common to all." The Rule of St Benedict, op. cit., Chap. 33, p. 65.

311. Supply vult after fieri. The Rule of St. Benedict, Chap. 70, p. 121: "What thou wouldst not have done to thyself, do not thou to another."

320. Proverbial; also in Reinardus and Renner.

321. With Voigt instead of acessit.

326. A biblical echo: John 17, 12; 18, 9.

332. Genesis $27,3$.

347-351. These five lines, in composite, resemble lines in Hor. Ep. 2, 1, 190; 2, 1, 183 f.; 2, 1, 212; and Sat. 1, 3, 110.

353. Perhaps ille $=$ 'the'.

363. MS A has faxa. B corrects to saxa - one of the few examples where B, neglected by Grimm and deriving from $A$, improves upon it.

368. ariete, here literally 'ram,' not the war machine of the ancients, with perhaps a suggestion of humor.

371. I adopt von Winterfeld's Si non sola potest... (or perhaps Peiper's Non solitum potis est - ?) for the impossible Non solitum potest.

$394 \mathrm{ff}$. The order follows von Winterfeld's proposal; decatie instead of decanie according to Voigt. Tithes were awarded the Church in 813 (see 1.69 above).

411. Hor. Ep. 2, 2, 104: finitis studiis, here humorously varied.

412. The reading lassescenti (Grimm) improves the ms lassessens.

417. Hec: It must be borne in mind that vulpes is feminine, and thus the fox becomes a Virgilian queen (1. 434: Aen. 11, 845)!

419. "Monks shall practice silence at all times..." "One or two seniors shall be appointed to go about the monastery at such times as the brethren are free to read, in order to see that no one is slothful, given to idleness or foolish talking..." The Rule of St. Benedict, op. cit., Chap. 42, p. 76; Chap. 48, p. 86.

422. fini is an old dative of direction. See 1. 455.

423. On monastica vulpes see Jauss.

424. Last verse of the Psalter. 
$433 \mathrm{ff}$. The significance of this is probably connected with pagan iconic tree mysticism. ls humor involved in posteriora?

446. See Luke $5,1$.

450. Act. Apost. 8, 2.

465. St. Aper, the saint of the monastery (St. Evre) of Toul.

480. happy $=$ long-lived.

492. Strecker corrects from illis.

$542 \mathrm{f}$. and $550 \mathrm{f}$. are strongly under the influence of Marcellus, De medicina 29, 23, and 47. tellure creatis and ...creatas both occur there.

547. Qui for quod is my emendation, suggested by Strecker.

549. The huic instead of hic is my suggested emendation.

551. fraglant $=$ fragrant. An echo of Dracontius?

560. illi looks like the definite article.

$561 \mathrm{f}$. The only echoes of Bede, De die iudicii $(85,93)$ in Ecbasis.

$569 \mathrm{ff}$. Voigt suggested placing 1. 571 before 1. 570, and von Winterfeld proposed the order adopted here.

570. Proverbial.

572. "Let there be stationed at the gate of the monastery some wise old man who knows how to give and receive an answer. As soon as anyone shall knock, or some poor man shall call for help, let him reply Thanks be to God, or invoke a blessing. And let him in the meekness of God's fear hasten to reply with zealous charity..." Rules of St. Benedict, op. cit., Chap. 66, p. 117.

582. Ibid., Chap. 5.

583. The story of Malchus, told by St. Jerome (Hieronymus) - De Vita Malchi - is here recited by the unicorn. See Introduction, also 1. 790. Grimm, p. 287, conjectured that Malchus was the monastic name of the Ecbasis author. It may well be that the Ecbasis story of the calf is a reflection of the Malchus plot, although in the latter a sheep, and not a calf, is mentioned.

590. See $11.433 \mathrm{ff}$.

603. The first of three echoes of the Poetae of Johannes Scotus. See also 11. 922 and 984. 624 f. Deut. 25, 4.

636. Leopardus is in square brackets because the designation is missing in Ms A. The second king here seems to be the fox (see 1. 560) but is actually the panther. See 11.765 and 1000.

638. The mss have gentacula.

660. The MSS reading is: quam nobilis compilet. I follow Fickermann's suggestion: quam nobis. compilat is my own conjecture. In MS B Ericius is next to 1.661 , and 1.660 is still the leopard's. This was approved by Grimm.

661. This and the following speeches are typically mock-heroic.

687. Stensile is probably Stinzel on the Saar river (not Steinsel in Luxemburg). This follows Grimm's conjecture (p. 289) and contradicts Voigt (p. 15). See Strecker, p. 45. But Hartmut Hoffmann goes back to Luxemburg.

689. cameram lecti $=$ OHG pettichamera . Hunsaloa is probably Hundlingen near Saargemünd. 
$693 \mathrm{ff}$. The designation of speakers is confused. MS A assigns 1.693 to the leopard, 1. 694 to Ericius, 11. 695-697 to the leopard. But since there is no room in the margin of 1. 693, Leopardus appears behind 1.693 in A. Then there is no designation of speakers until 1. 706, when Vulpes speaks. Later a corrector of Ms A wrote Ericius next to 1. 694, Leapard (with $o$ above the first $a$ ) next to 1. 695, Ericius next to 1. 698, and Leppardus (corrected to Leopardus) next to 1. 699. However, with Grimm I still assign 1. 693 to Ericius, beginning the leopard's speech with 1. 694 and extending it to 1. 697. In MS B the designations are all erroneous.

718. ad presens sounds Germanic.

741. The reading in the mss is Dehitor es. But then it should be creditor es. See Voigt. If, as Voigt and Strecker suggest, we read en (i.e. en ego) for es, the sense is restored.

746. Proverbial.

$759 \mathrm{ff}$. I follow the excellent suggestions of Otto Schumann (see note on 11. $299 \mathrm{ff}$.) in his review of the Strecker edition. Fickermann had supplied pardus in the gap, added Leo as the speaker of 1.759, and Leopardus leoni as the speaker of 11.760-761. MS A has Leo next to 1. 761, while von Winterfeld puts it next to 1. 762. The Mss have scit in 1. 759 .

763. Act. Apost. 23, 12.

765. This line echoes both Hor. Sat. 2, 5, 48 and also Genesis $41,40 \mathrm{f}$.

767. Psalms 35, 8, and $141,9$.

771. That is, as far as Psalm 132.

774. Daniel 3, $20 \mathrm{ff}$.

781. I follow Seiler. The ms reading In speciem regnis viruit is corrupt.

789. A parody of Hrabanus Maurus, Hymnus Sanctorum meritis 4, 2.

797. I follow Peiper. The manuscript reading: Huncce regem decoret, regem cum decorc salvet is corrupt.

798-803. This passage echoes Marcellus De medicina 72, 73, 75-77, with which 11. 799-803 are almost identical.

814. 1 Kings $10,1 \mathrm{ff}$.

817. filomena: see $1.829 \mathrm{ff}$. below.

826. Gabriel, Hemmanuel: See Isaiah 7, 14, and Luke 1, $26 \mathrm{ff}$.

829 ff. Filomena, Philomena, Philomela etc., the nightingale. See 11. 873, 1063, and 1066. See also Grimm, p. 322.

837. Act. Apost. 2, 1.

$844 \mathrm{f}$. Matthew 27, 45, and 51.

847. The Ms reading is matrem. I read matre (abl. of agent without prep. $a-c f .1 .766$ ) for better sense.

851. linquere non potui sounds Germanic.

852. With the square bracket the interpolation (or two interpolations: 11. 852-880, and $881-905)$ begins. Von Winterfeld would extend it through 1.907. See Introduction. It is to be noted that with the exception of an echo of Virg. Ecl. 9, 11 in 1.853 (Audieras? Et fama fuit...) and possibly one of Hor. Carm. 1, 3, 18 in 1.897 (Qui siccis oculis monstra natantia), all the echoes in the interpolation are from writers of the Christian era, especially the Arator. The fact that the first half of 1.905 is from Virg. Aen. 3, 461, might tend to suggest that the line does not belong to the interpolation. 
889. corde $=$ chordae.

899. Isaiah 53, 7, and Act Apost. 8, 32. Pontius Pilate is meant.

$900 \mathrm{ff}$. Mark 14, 65 ff.

916. The MS reading: geris imperfectum. I follow von Winterfeld.

923. The distribution of speakers follows Voigt.

943. On the Frankish horns see Grimm, 327.

945. Psalms 50; $73 \mathrm{ff}$.

947. Psitacus, supplied by von Winterfeld, hence in square brackets.

954. federe iunxit (cf. 1. 950) is a set conventional phrase.

961. Ms A has imo, which Grimm and Voigt correct to imno =s hymno. For no apparent reason Strecker has immo (a misprint?).

962. Severini festa beati, October 21.

977. The first three words are from a well-known Easter hymn.

992. This proverbial saying is from Hor. Ep. 1, 18, 89.

995. Act. Apost. 16, 31.

1010-1015: A break in the "inner fable"; the wolf and the otter of the "outer fable" speak.

1013. Ms A assigns 11. 1013-1015 to Litter. Strecker suggests my change, giving 1. 1013

still to Lupus and only 11. 1014-1015 to Luter.

1014. Ezechiel 18, 2.

1026. Poma Geroldinga are mentioned also in the Capitulare de villis (Capit. reg. Franc.) 1, 1883, 91-92, of 812 of Charlemagne. See Grimm, 292. Ms B knows nothing of them and has gero digna instead.

1033. The Prologue of the Rule of St. Benedict speaks of "the ear of thine heart."

1043. Matthew 15, 30.

1044. I.e., they show by their insults that silence is golden.

1047. An extreme example of how the author echoes Horace, his favorite author: tua (sua) culpa premit (premet) is from Ep. 1, 18, 79, while the rest of the line is from 1.87 of the same Epistle. Ecbasis 1048 is word for word from Ep. $\mathrm{i}, 18,88$.

1057. Isaiah 40, 6.

1069. Physiologus, Chap. I: Un. of Calif. Publicats. in Class. Philol. XII, 1944, 103, where the number three is associated with the lion in various ways.

1073. revisit: If re- is taken literally, this might be interpreted as a return home. Both MSs have suuaz uualt (corrected by Grimm). Perhaps the copyists were Gallic.

1075. The swan is considered a northern bird, as Cygnus is a northern constellation. On these birds see Hartmut Hoffmann, $310 \mathrm{f}$.

1081. Grimm supplied the missing des.

1085. Proverbial.

1098. My reading is based upon suggestions of Peiper and Strecker. (not abesset).

1108. I.e., let him be consumed by the birds who...

1109. sublaterans, corrected by Grimm from sublatans. I am not sure of the meaning here.

See Voigt pp. 135 and 149.

1114. Perhaps an echo of Hrotsvit, Call. 9, 29 (von Winterfeld ed.).

1115. See Prov. 26, 27, also Eccles. 10, 8.

1116. See Rom. 2, 12. 
1118. Ylerda, a town in Spain. See Hor. Ep. 1, 20, 13: aut vinctus mitteris Ilerdam.

1130. An echo of Hor. Sat. 2, 4, 93, 92.

1133. See Hor. Sat. 2, 6, $94 \mathrm{f}$.

1139. See 1. 329.

1140. The West Franks are meant.

1142. I adopt Fickermann's suggested order, placing 1. 1141 after 1. 1156. Strecker also adopts it but confuses the enumeration between 11.1140 and 1155 .

1149. See Introduction.

1162. Since works of the time are often built around proverbial truths such as this from Horace, De arte poetica, 1. 350, or around well-known sayings, we may see here one possible point of departure for the author. See also 11.248 and 308.

1164. Like a Roman at the circus!

1176. istis looks like a definite article.

1204. fastidia magnum seems a strange expression. magnum must be a cognate accusative. The fact that fastidia magna (cf. also 1. 1019) occurs in the line before, might make this recurrence suspect as a corrupt reading. See also amarum - amaras, 11. 1207 and 1208.

1208. Bitter weeping has been conventional since Matthew 26, 75, and Luke 22, 62.

1216. See Matthew 2, 16.

1217. See 1. 272. But here the wolf has become Herod!

1223. Psalms 113, 2.

1224. See Introduction.

$1225 \mathrm{ff}$. The last five lines are taken over, almost without change, from the author's favorite Horace: De arte poetica 360; Ep. 2, 2, $141 \mathrm{f}$. (Ms A has me instead of et; Horace has pueris instead of psalmis); Ep. 2, 2, 29; and Sat. 1, 1, 121 (Horace has compilasse instead of sermonem claudam). In 1226 the author reverts to his theme at the beginning 


